\title{
DERIVADOS PORFIRÍNICOS COMO FOTOSSENSIBILIZADORES PARA TERAPIA FOTODINÂMICA
}

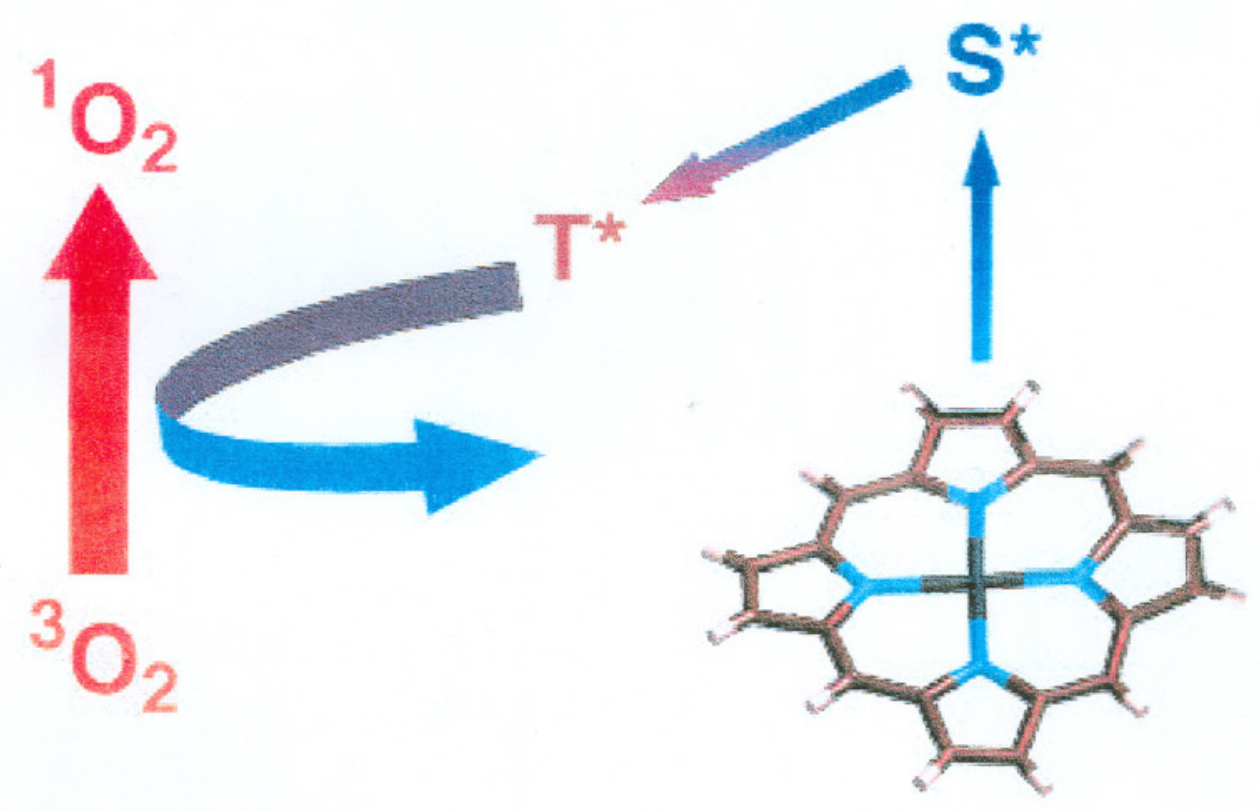

Fábio Monaro Engelmann

TESE DE DOUTORADO

Orientador: Prof. Dr. Koiti Araki 


\section{"Derivados porfirínicos como fotossensibilizadores para terapia fotodinâmica"}

\section{FÁBIO MONARO ENGELMANN}

Tese de Doutorado submetida ao Instituto de Química da Universidade de São Paulo como parte dos requisitos necessários à obtenção do grau de Doutor em Química - Área: Química Inorgânica.

Aprovado(a) por:

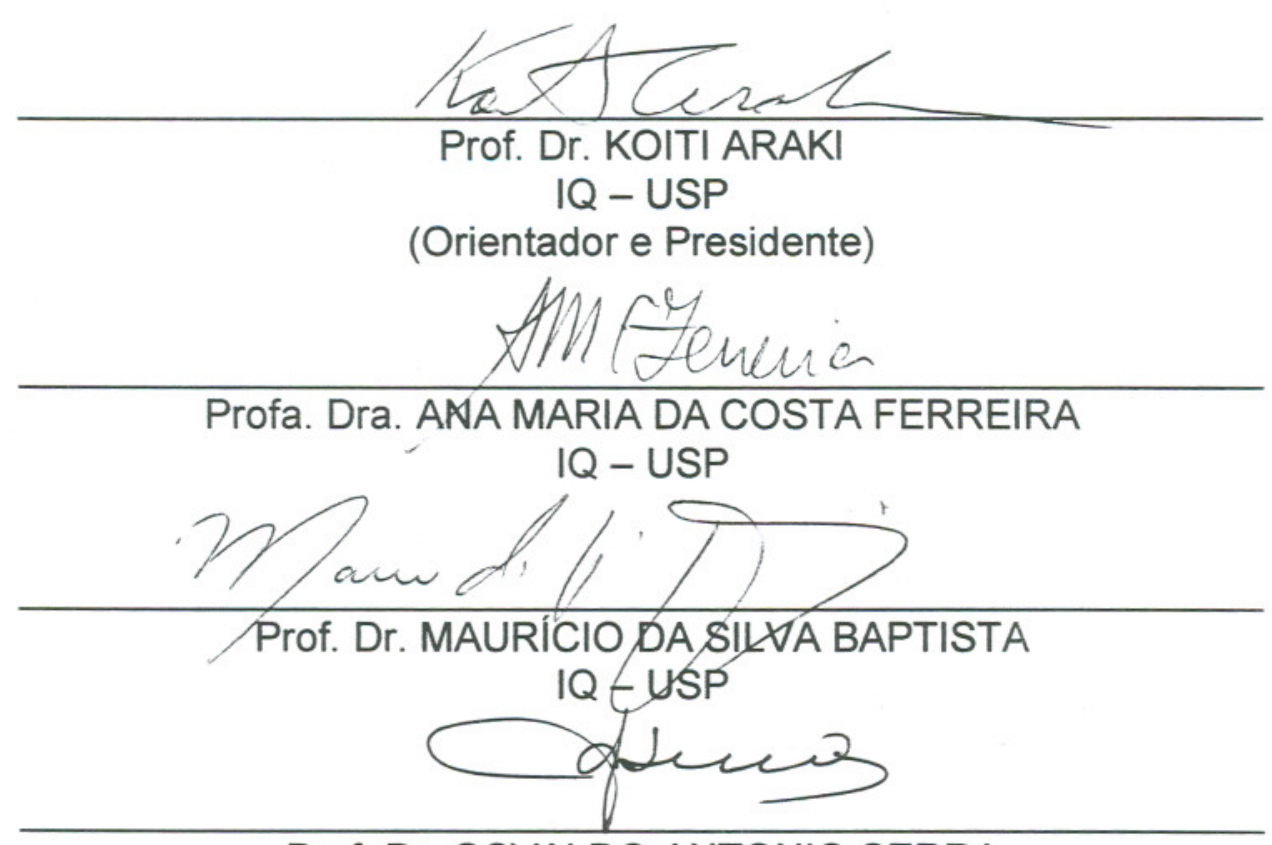

Prof. Dr. OSVALDO ANTONIO SERRA

FFCLRP - USP

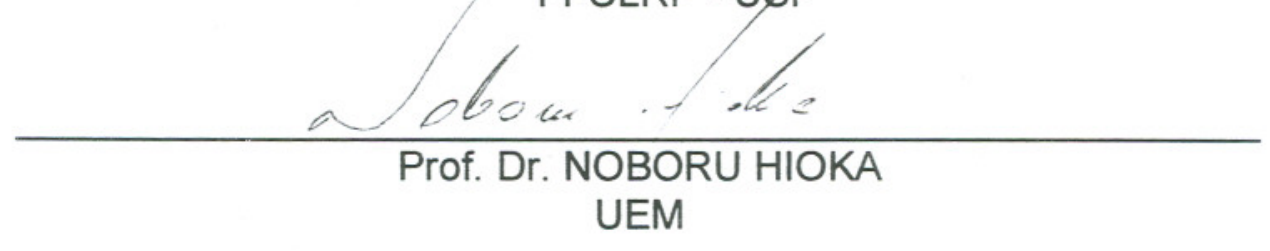




\section{ÍNDICE}

$\begin{array}{llr}1 . & \text { RESUMO } & 8\end{array}$

$\begin{array}{ll}\text { 2. ABSTRACT } & 12\end{array}$

3. INTRODUÇÃO 15

3.1. TERAPIA FOTODINÂMICA COMO UM TRATAMENTO ANTI-NEOPLÁSICO ALTERNATIVO

3.2. MECANISMOS DE ATUAÇÃO DOS FOTOSSENSIBILIZADORES 17

3.2.1. A FORMAÇÃO DE OXIGÊNIO SINGLETE - ${ }^{1} \mathrm{O}_{2}$

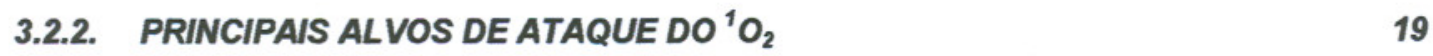

3.3. IRRADIAÇÃO DO TECIDO ANIMAL 21

3.4. INTERAÇÃO DO FOTOSSENSIBILIZADOR COM O TECIDO 23

$\begin{array}{lll}\text { 3.5. TIPOS DE FOTOSSENSIBILIZADORES } & 27\end{array}$

3.6. INTERCALAÇÃO AO DNA 31

4. EQUIPAMENTOS E MÉTODOS 37

4.1. ESPECTROS DE ${ }^{1} H-R M N$ E COSY

$\begin{array}{lll}\text { 4.2. ESPECTROS ELETRÔNICOS } & 38\end{array}$

4.3. CINÉTICA DE DECOMPOSIÇÃO 38

4.4. MEDIDAS DE LUMINESCÊNCIA

$\begin{array}{ll}\text { 4.5. FOTÓLISE RELÂMPAGO } & 39\end{array}$

4.6. RENDIMENTO QUÂNTICO DE OXIGÊNIO SINGLETE ( $\left.\phi_{\Delta}\right)$

4.7. COEFICIENTE DE PARTIÇÃo n-OCTANOLÁGUA (logPoN OU nBUTANOLÁGUA (LogPA) 
4.8. EFICIÊNCIA DA HEMÓLISE DE ERITRÓCITOS

4.9. INTERAÇÃO DAS PORFIRINAS CATIÔNICAS COM MITOCÔNDRIAS ISOLADAS E EFEITO DA IRRADIAÇÃO

4.10. INTERAÇÃO COM LIPOSSOMOS

4.11. INTERAÇÃO COM FIBROBLASTOS CANCEROSOS HELA 53

5. PORFIRNAS CIS DUPLAMENTE N-CONFUSAS 55

5.1. RESULTADOS E DISCUSSÕES 55

5.1.1. ESTUDOS DE LUMINESCÊNCIA

5.1.2. ESTADO EXCITADO TRIPLETE E RENDIMENTO QUÂNTICO DE ${ }^{1} \mathrm{O}_{2}$

5.1.3. ESTUDO DE FOTODECOMPOSIÇÃO 68

5.2. CONCLUSÃO

6. MESO-(PIRIDIL)FENILPORFIRNAS $\quad 75$

6.1. RESULTADOS E DISCUSSÕES

6.1.1. SINTESE E PURIFICAÇÃO DAS MESO-(PIRIDIL)FENILPORFIRINAS 75

6.1.2. SÍNTESE E PURIFICAÇÃO DAS MESO-(N-METILPIRIDÍNIO)PORFIRINAS 77

6.1.3. SÍNTESE E PURIFICAÇÃO DAS MESO-(PIRIDIL)PORFIRINAS RUTENADAS 80

6.1.4. RENDIMENTO QUÂNTICO DE FORMAÇÃO DE ${ }^{1} \mathrm{O}_{2}-\phi_{4}$

6.1.5. COEFICIENTE dE PARTIÇÃo n-OCTANOLÁGUA (LogPoN OU nBUTANOLÁGUA $\left(\log P_{B A}\right) \quad 89$

6.1.6. HEMÓLISE DE ERITRÓCITOS $\quad 95$

6.1.7. INTERAÇÃO COM MITOCÔNDRIAS ISOLADAS 103

6.1.8. INTERAÇÃO COM LIPOSSOMOS

6.1.9. INTERAÇÃO COM FIBROBLASTOS CANCEROSOS HE-LA 116

$\begin{array}{ll}\text { 6.2. CONCLUSÃO } & 118\end{array}$

Fábio Monaro Engelmann $\quad$ Tese de Doutorado 
$\begin{array}{ll}\text { 7. BIBLIOGRAFIA } & 123\end{array}$

$\begin{array}{lr}\text { 8. CURRICULUM VITAE } & 129\end{array}$ 


\section{AGRADECIMENTOS}

A Deus, pelo dom da vida e por cuidar de mim e dos que gosto.

À minha esposa, pela paciência, compreensão, amor e carinho.

Ao Prof. Koiti Araki, pela orientação, paciência, pelas discussões e amizade.

Ao Prof. Maurício S. Baptista e seus alunos, Dino, Carla, Diane, Elena, Adjaci e Divino, pela amizade e orientação nos experimentos na área de bioquímica e fotoquímica.

À Profa. Alicia Kowaltowski, pela amizade, orientação e por abrir as portas do seu laboratório. Aos seus alunos, Erich, Herbert, Crasieli, Raquel e Camile, pela amizade e discussões.

À Profa. Ana Maria Ferreira pela amizade e discussões.

Aos colegas do laboratório de Química Supramolecular e Nanotecnologia, Ildemar, Luis, Sérgio, Formiga, Juliano, Marcelo, Márcio, Izilda, Herbert, Ronaldo, Vitor e Leonardo pelas discussões, amizade e "parceria".

Aos colegas Ildemar, Luis e Sérgio pelos cafezinhos do B6.

À Fapesp pelo financiamento. 
$\tau \quad$ tempo de vida do estado excitado singlete $\left(\mathrm{S}_{1}\right)$ ou triplete $\left(\mathrm{T}_{1}\right)$

$\tau_{\text {oxi }}$ tempo de vida do oxigênio singlete 35 série das porfirinas contendo 1 , 2 (trans), 2 (cis), 3 e 4 substituintes $N$-3-piridil ligados à posição meso do anel

$4 S$ série das porfirinas contendo 1 , 2 (trans), 2 (cis), 3 e 4 substituintes $N$-4-piridil ligados à posição meso do anel

3SMe série das porfirinas contendo 1 , 2 (trans), 2 (cis), 3 e 4 grupos $N$-3metilpiridínio ligados à posição meso do anel

4SMe série das porfirinas contendo 1 , 2 (trans), 2 (cis), 3 e 4 grupos $N$-4metilpiridínio à posição meso do anel

3PMe cloreto de $\operatorname{mono}(\mathrm{N}-3-$ metilpiridínio)trifenilporfirina

${ }_{3 P_{2 t}} \mathrm{Me}$ cloreto de trans-di $(N-3-$ metilpiridínio)difenilporfirina

$\mathbf{3 P}_{2 \mathrm{c}} \mathrm{Me}$ cloreto de cis-di $(\mathrm{N}-3-$ metilpiridínio)difenilporfirina

3P $\mathbf{P}_{3} \mathrm{Me}$ cloreto de metilpiridínio)monofenilporfirina

3P 4 Me cloreto de tetra( $N-3$ metilpiridínio)porfirina

3PRu $\mu-\{(N$-3-piridil)trifenilporfirina $\}$

\{bis(2,2'-bipiridil)clororutênio(II)\}

${ }_{3} \mathbf{P}_{2 c} \mathbf{R u} \quad \mu_{2}-\{c i s-d i(N-3-p i r i d i l) d i f e n i l p o r f i r i n a\}-$ bis $\{$ bis(2,2'-bipiridil)clororutênio(II)\}

3P $\mathbf{P}_{2 \mathbf{t}} \mathbf{R u} \quad \mu_{2}-\{$ trans-di $(N-3-$

piridil)difenilporfirina\}-bis \{bis(2,2'-bipiridil)cloro rutênio(II)\}
3P $\mathbf{P}_{3} \mathbf{R u} \quad \mu_{3}-\{$ tri( $N$-3-piridil)fenilporfirina\}tris\{bis(2,2'-bipiridil)clororutênio(II)\}

3P $\mathbf{P}_{4} \mathbf{R u} \quad \mu_{3}-\{$ tetra( $N$-3-piridil) porfirina\}-

tetrakis\{bis(2,2'-bipiridil)clororutênio(II)\}

4PMe mono( $N-4-$

metilpiridínio)trifenilporfirina

4P $\mathbf{P}_{2 t}$ Me trans-di(N-4-

metilpiridínio)difenilporfirina

$\mathbf{4 P}_{2 \mathrm{c}} \mathrm{Me}$ cis-di( $\mathrm{N}-4-$

metilpiridínio)difenilporfirina

$\mathbf{4 P}_{3} \mathrm{Me} \quad \operatorname{tri}(\mathrm{N}-4-$

metilpiridínio)monofenilporfirina

$\mathbf{4} \mathbf{P}_{\mathbf{4}} \mathbf{M e}$ tetra( $N$-4-metilpiridínio)porfirina

3PRu $\quad \mu-\{(N-4-p i r i d i l)$ trifenilporfirina $\}-$

\{bis(2,2'-bipiridil)clororutênio(II)\}

${ }_{3} \mathbf{P}_{2 c} \mathbf{R u} \quad \mu_{2}-\{$ cis-di( $N$-4-piridil)difenilporfirina $\}$ bis $\{$ bis(2,2'-bipiridil)clororutênio(II)\}

3P $\mathbf{P}_{2 \mathrm{t}} \mathbf{R u} \quad \mu_{2}-\{$ trans-di( $N-4-$ piridil $)$

difenilporfirina\}-bis\{bis(2,2'-

bipiridil)clororutênio(II)\}

$\operatorname{tri}\left(N-3-\quad 3 \mathbf{P}_{3} \mathbf{R} \mathbf{u} \quad \mu_{3}-\{\operatorname{tri}(N-4-\right.$ piridil $) f e n i l p o r f i r i n a\}$

tris $\{$ bis(2,2'-bipiridil)clororutênio(II)\}

3P $\mathbf{P}_{4} \mathbf{R u} \quad \mu_{3}-\{$ tetra( $N$-4-piridil)porfirina\}-

tetrakis\{bis(2,2'-bipiridil)clororutênio(II)\} 


\section{RESUMO}

Nesta tese serão discutidos alguns aspectos químicos, fotoquímicos e fotofísicos importantes no desenvolvimento de fotossensibilizadores para aplicação em terapia fotodinâmica (TFD). Os estudos abrangeram a investigação de 29 espécies, sendo que 20 delas continham um anel porfirínico convencional e 9 eram porfirinas duplamente $\mathrm{N}$-confusas. As primeiras foram sintetizadas para apresentarem diferentes números e tipos de substituintes catiônicos coordenados à posição meso do anel porfirinico, mais especificamente as meso( $N$-4-piridil)fenilporfirinas e as meso( $N$-3piridil)fenilporfirinas contendo um, dois (em trans), dois (em cis), três e quatro grupos [Ru(bipy) ${ }_{2} \mathrm{Cl}^{+}$ou $\mathrm{CH}_{3}{ }^{+}$(figura 1).

Em contraste com as porfirinas convencionais, as outras 9 estruturas consistiram das formas protonadas, neutras e desprotonadas de porfirinas que exibem dois anéis pirrólicos adjacentes voltados para fora do anel porfirínico, mais especificamente a base livre $\left(\mathrm{H}_{2} \mathrm{~N}_{2} \mathrm{CP}\right)$ e os respectivos complexos de prata $\left(\mathrm{AgHN} \mathrm{N}_{2} \mathrm{CP}\right)$ e de cobre $\left(\mathrm{CuHN}_{2} \mathrm{CP}\right)$. Esta peculiaridade estrutural permite coordenar metais de transição por meio de dois átomos de carbono e dois de nitrogênio, estabilizando fortemente íons metálicos em estados de oxidação anormalmente elevados como $\mathrm{Ag}^{3+}$ e $\mathrm{Cu}^{3+}$. Os dois nitrogênios pirrólicos externos ao anel são susceptiveis tanto a protonação quanto a desprotonação, possibilitando a modulação das propriedades eletrônicas desses compostos por simples alteração no pH do meio. De um modo geral, a acidificação das amostras perturbou mais significativamente suas propriedades fotoquímicas que a desprotonação. Em especial, as espécies neutras metaladas apresentaram bandas bastante intensas na região fototerapêutica de 600 a 750 nm, além de um elevado rendimento quântico de formação de oxigênio singlete $\left(\phi_{\Delta}>0,90\right.$ para o complexo $\left.\mathrm{Ag}(\mathrm{III})\right)$. Todavia, um processo de fotodecomposição atribuido ao ataque do ${ }^{1} \mathrm{O}_{2}$ formado, também foi observado. Ambos os processos, $\phi_{\Delta}$ e fotodecomposição, parecem ser modulados pelo metal coordenado no centro do anel. Tanto a coordenação de $\mathrm{Ag}$ (III) como $\mathrm{Cu}(\mathrm{III})$ aumentou $\mathrm{o} \phi_{\Delta}$, provavelmente devido ao efeito do metal pesado sobre o cruzamento interssistema. Todavia, verificou-se que o derivado $\mathrm{AgHN}_{2} \mathrm{CP}$ é 
muito menos reativo que $0 \mathrm{CuHN}_{2} \mathrm{CP}$ e a base livre. Os motivos deste comportamento ainda não são completamente compreendidos, mas é evidente que o complexo de $\mathrm{Ag}$ (III) apresenta melhores propriedades fotodinâmicas que as demais.

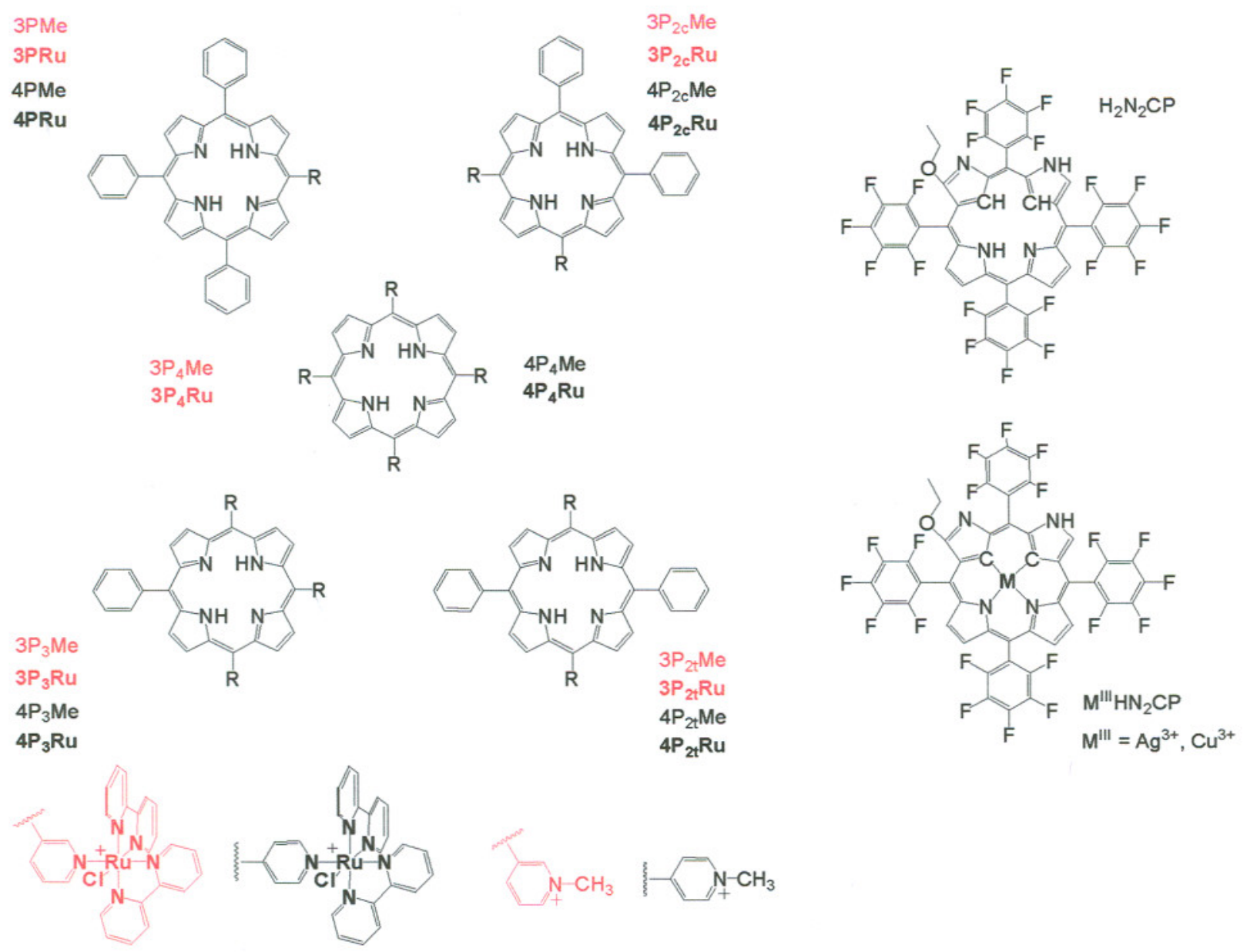

Figura 1: Estruturas das meso-(N-3-piridil)fenilporfirinas (ou série 3, 3S) e meso-( $N$-4-piridil)fenilporfirinas (ou série 4, 4S) coordenadas a complexos de rutênio $\left(\mathrm{Ru}=\left[\mathrm{Ru}(\text { bipy })_{2} \mathrm{Cl}\right]^{+}\right)$ou grupos metila $\left(\mathrm{Me}=\mathrm{CH}_{3}{ }^{+}\right)$. O número que antecede a sigla do composto refere-se à posição do átomo de nitrogênio na piridina e o número subescrito à quantidade daqueles grupos catiônicos presentes nas moléculas. $\dot{A}$ direita, estão as estruturas das porfirinas duplamente $\mathrm{N}$-confusas, a base livre $\left(\mathrm{H}_{2} \mathrm{~N}_{2} \mathrm{CP}\right)$ e os complexos de prata $\left(\mathrm{AgHN}_{2} \mathrm{CP}\right)$ e de cobre $\left(\mathrm{CuHN}_{2} \mathrm{CP}\right)$. 
Em comparação com as porfirinas duplamente $\mathrm{N}$-confusas, as demais 20 porfirinas catiônicas são muito mais solúveis em água. Neste caso, 0 enfoque dos experimentos foi direcionado às aplicações biológicas propriamente ditas. Assim, além das propriedades fotofísicas associadas à formação de oxigênio singlete $\left({ }^{1} \mathrm{O}_{2}\right)$, também foram exploradas a influência do número dos substituintes periféricos sobre a ligação e danos fotooxidativos provocados em eritrócitos, lipossomos, mitocôndrias e células cancerigenas.

Os resultados de $\phi_{\Delta}$ mostraram ser inversamente proporcionais ao número de cargas positivas, para as porfirinas contendo grupos $\mathrm{N}-4$ metilpiridíniom. Estas diferenças foram consistentes com os efeitos de agregação, causados pela formação de dímeros ou oligômeros, no caso das espécies mais hidrofóbicas. Os coeficientes de partição em $n$ octanol/água $\left(\log \mathrm{P}_{\mathrm{OA}}\right)$ corroboraram estes resultados, apresentando uma dependência inversamente proporcional ao número de cargas positivas ou proporcional ao número de resíduos fenila.

As eficiências de ligação à bicamada lipídica mitocondrial, lipossomal e celular e os processos de peroxidação lipídica fotoinduzidos mostraram uma dependência proporcional aos valores de $\log \mathrm{P}_{\mathrm{OA}}$, exceto para as porfirinas contendo complexos de rutênio. $O$ comportamento não linear neste último caso pode estar associada a dissociação da ligação rutênio-porfirina, devido a elevada força iônica das soluções fisiológicas utilizadas. Neste caso, a descoordenação dos complexos periféricos deve promover uma drástica diminuição da solubilidade do composto. Por este motivo os experimentos foram conduzidos somente com as espécies metiladas.

No caso, de mitocôndrias isoladas verificou-se que a interação também apresenta uma razoável participação do potencial de membrana. De fato, quando a mitocôndria estava energizada foi observado um acréscimo de 15\% no acúmulo da $3 \mathrm{P}_{2 \mathrm{c}} \mathrm{Me}$ em comparação com à mitocôndria desacoplada. Para as demais porfirinas houve um menor acúmulo com o aumento do número de resíduos $\mathrm{N}$-3-metilpiridínio.

Em todos os experimentos, um comportamento diferenciado foi observado no caso dos isômeros dicatiônicos. A espécie com cargas dispostas 
nas posições cis $\left(3 \mathrm{P}_{2 c} \mathrm{Me}\right)$ apresentou praticamente o dobro de eficiência que 0 correspondente isômero trans $\left(3 \mathrm{P}_{2 t} \mathrm{Me}\right)$. Este comportamento parece consistente com uma maior penetração da primeira espécie na bicamada lipídica, proporcionado pelo caráter anfipático de sua estrutura química.

Os resultados apresentados neste estudo mostraram que estas séries de meso-porfirinas catiônicas constituem sistemas bastante interessantes para a compreensão dos efeitos estruturais envolvidos na ação fotodinâmica dos compostos sobre membranas lipídicas, devido à possibilidade de modulação da relação hidrofilicidade/lipofilicidade, sem alterar significativamente a eficiência na formação de ${ }^{1} \mathrm{O}_{2}$. Além disso, a disposição espacial das cargas positivas na estrutura do fotossensibilizador demonstrou ser extremamente crítica no processo de ancoragem do mesmo na membrana celular ou mitocondrial e consequentemente em causar efeitos fotooxidativos mais eficientemente. As porfirinas contendo grupos 3-metilpiridinio apresentam vantagens sobre as 4-metilpiridinio, normalmente estudas, por serem mais hidrofílicas, terem menor tendência de agregação e possuírem similar atividade fotodinâmica. Em especial, a estrutura anfipática da $3 \mathrm{P}_{2 c} \mathrm{Me}$ associada a sua elevada formação de ${ }^{1} \mathrm{O}_{2}$ e estabilidade lhe conferem uma interessante potencialidade como agente fototerapêutico. 


\section{ABSTRACT}

In this thesis the chemical, photochemical and photophysical relevant aspects for the development of new photosensitizers for photodynamic therapy applications are discussed. 20 conventional porphyrins species and 9 doubly $\mathrm{N}$ confused porphyrins species were investigated. The first series contains variable number (1 to 4) of cationic groups, $\left[\mathrm{Ru}\left(\text { bipy) }{ }_{2} \mathrm{Cl}\right]^{+}\right.$or $\mathrm{CH}_{3}{ }^{+}$(figure 1), bound to the meta or para-pyridil $\mathrm{N}$-atoms of meso-phenylpyridylporphyrins. On the other hand, the protonated, neutral and deprotonated doubly $\mathrm{N}$-confused porphyrins possess two rotated adjacent pyrrol rings, such that they have two coordinating carbon atoms. Consequently, transition metal ions in unusually high oxidation states such as $\mathrm{Ag}(\mathrm{III})$ and $\mathrm{Cu}(\mathrm{III})$ can be stabilized by this structure, while the outer pyrrol $\mathrm{N}$-atoms are susceptible to protonation and deprotonation reactions, allowing the modulation of their electronic properties simply by controlling the $\mathrm{pH}$ of the solution. In general, the protonation perturbed more significantly the photochemical properties than the deprotonation.

The neutral species exhibit intense absorption bands in the phototherapeutical range $(600$ to $750 \mathrm{~nm})$, associated with a high singlet oxygen sensitization quantum yield ( $\phi_{\Delta}>0,90$ for the $\mathrm{Ag}$ (III) complex). Furthermore, a photodecomposition process due to the reaction with ${ }^{1} \mathrm{O}_{2}$ was also identified. Both $\phi_{\Delta}$ and photodecomposition are influenced by the metal ion coordinated to the doubly $\mathrm{N}$-confused porphyrin ring. The coordination of $\mathrm{Ag}(\mathrm{III})$ and $\mathrm{Cu}(\mathrm{III})$ increased $\phi_{\Delta}$, probably due to the enhancement of intersystem crossing quantum yield associated with the heavy atom effects. However, $\mathrm{AgHN} \mathrm{N}_{2} \mathrm{CP}$ is much more stable than $\mathrm{CuHN}_{2} \mathrm{CP}$ or the free-base, but the reasons are not clear and should be further investigated. The above results clearly evidence the superior properties of the $\mathrm{Ag}(\mathrm{III})$ complex as photosensitizer for PDT applications.

The 20 cationic pyridylporphyrin derivatives are much soluble in water and experiments directed to biological applications could be carried out. Accordingly, in addition to the quantum yield for singlet oxygen generation $\left({ }^{1} \mathrm{O}_{2}\right)$, 
the effect of the stereochemistry and number and position of the electrically charged substituents on the binding constants and photooxidative damage on erythrocytes, lipossomes, mitochondria and HeLa cells were evaluated. The $\phi_{\Delta}$ values were constant in the case of the $\mathrm{N}$-3-methylpyridinium derivatives but inversely proportional to the number of positive charges for the $\mathrm{N}$-4methylpyridinium derivatives. This was assigned to an increase of aggregation of the sensitizers as the number of meso-phenyl rings and the lipophylicity increase. The partition coefficients in $n$-octanol/water ( $\left(0 g \mathrm{P}_{\mathrm{OA}}\right)$ corroborate that assertion showing a linear correlation with increasing of the number of phenyl groups.

The binding efficiency towards the mitochondrial, lipossomal and cellular membrane and the photo-induced lipidic peroxidation processes were directly proportional to the $\log \mathrm{P}_{\mathrm{OA}}$, except for the ruthenated porphyrins. This last behavior may be associated with the dissociation reactions of the rutheniumpyridylporphyrin bond in the physiologic solution. Accordingly, those experiments were carried out only with the methylpyridynium derivatives.

For the first time, we showed inequivocally that the interaction of the methyllated porphyrins with mitochondria are significantly influenced by the membrane potential. In fact, when the mitochondria was energized a $15 \%$ increase was observed in the binding constants of $3 \mathrm{P}_{2 c} \mathrm{Me}$ in comparison with teh results with decoupled mitochondria. Also, the amount of bond porphyrin sensitizer decreased as the number of methylpyridynium groups was increased, following the same tendency as above.

The behavior of the cis $\left(3 \mathrm{P}_{2 \mathrm{c}} \mathrm{Me}\right)$ and trans $\left(3 \mathrm{P}_{2 \mathrm{t}} \mathrm{Me}\right)$ isomers didn't follow the general tendency for the other derivatives in a series, such that the binding constants of the cis isomers were always about twice higher than for the trans, which were much higher than predicted by the general behavior. This means that they can associate more strongly and penetrate deeper in the membrane than the more charged porphyrin derivatives. In particular, the cis species is amphiphilic, i.e. possess an adequate structure for that interaction.

The results presented in this thesis showed conclusively that the two series of meso-phenylpyridylporphyrins are adequate for the investigation of the 
effect of the stereochemistry on the bonding ability and photodynamic properties of those photosensitizers. This is particularly true due to the possibility of modulating the ratio between hydrophobicity/hydrophylicity and the stereochemistry without influencing significantly the quantum yield for ${ }^{1} \mathrm{O}_{2}$ generation. The meta- series showed an advantage over the conventionally used para- series of methylpyridynium porphyrins because it is more soluble and shows lesser tendency to aggregate. In conclusion, the amphiphilic $3 \mathrm{P}_{2 c} \mathrm{Me}$ is the species with the highest potentiallity as PDT sensitizer because of its high binding constants, low tendency to associate and high $\phi_{\Delta}$. 


\section{INTRODUÇÃO}

\subsection{TERAPIA FOTODINÂMICA COMO UM TRATAMENTO ANTI- NEOPLÁSICO ALTERNATIVO}

O câncer [1-6] é uma doença normalmente caracterizada por um crescimento desordenado de algumas células de um dado tecido, formando uma massa celular que se infiltra e comprime as regiões circunvizinhas causando dor ao indivíduo. Sua formação freqüentemente é atribuída a alterações cromossômicas ocorridas durante o ciclo de divisão celular. Neste caso, estas mutações geram anomalias metabólicas e podem levar a perda nos mecanismos de controle da divisão celular.

Dentre os tratamentos mais freqüentemente empregados estão a intervenção cirúrgica, a quimioterapia e a radioterapia. A primeira é normalmente utilizada na remoção física de tumores grandes ou pequenos, internos ou de pele. Todavia, para considerar uma margem de segurança, geralmente um volume maior da região tumoral é removido. Portanto, este procedimento pode causar, em alguns casos, amputações e desfiguração do paciente, prejudicando sua auto estima e seu relacionamento social.

O tratamento utilizando quimioterápicos faz uso de drogas antineoplásicas que frequentemente apresentam a função de inibir a mitose, interferindo com o metabolismo dos ácidos nucléicos ou promovendo distúrbios específicos em processos bioquímicos, como a inibição de certas reações enzimáticas. Infelizmente os efeitos deletérios destes compostos não estão restritos somente as células neoplásicas, mas na maioria dos casos, também atinge às células normais. De maneira geral, os efeitos tóxicos dos agentes anti-neoplásicos são náuseas, vômitos, depressão da contagem sangüínea periférica, que podem se tornar severas com o aumento das doses.

Na radioterapia [1], é ministrado ao local do tumor um feixe de raios ionizantes (raio-X). Estes raios de alta energia geram espécies altamente reativas por toda a célula, porém seus principais efeitos são lesões no DNA 
que acabam por bloquear a divisão celular. Assim, a ação da radioterapia apresenta uma maior eficiência em células que estão em constante processo de mitose, como as cancerigenas. A penetração do raio- $X$ no tecido é bastante elevada, atingindo inúmeras camadas de células sadias anteriores e posteriores a massa tumoral, incluindo vasos sanguíneos e linfáticos. Assim, os efeitos colaterais mais freqüentemente experimentados pelos pacientes sob tratamento são irritações ou leves queimaduras da pele, inflamações das mucosas, queda de cabelo nas áreas irradiadas e diminuições nas contagens das células do sangue, acarretando cansaço físico e baixa resistência a infecções.

Neste sentido, a terapia fotodinâmica (TFD) [7-10] vem se tornando uma ferramenta bastante útil como tratamento anti-neoplásico alternativo. Semelhante a uma combinação muito mais atenuada da quimioterapia e da radioterapia, a TFD faz uso de um fotossensibilizador inócuo, que normalmente se concentra nas células tumorais, e radiação inofensiva de baixa energia (na região de 600 a $750 \mathrm{~nm}$ ), para promover a destruição de tecidos anormais em regiões localizadas. Quando a região contendo o fotossensibilizador é irradiada, são geradas espécies altamente reativas, principalmente o oxigênio singlete $\left({ }^{1} \mathrm{O}_{2}\right)$, que ataca o tecido vivo causando a morte celular, quer por necrose [11,12] ou por indução da apoptose [2,13]. Desta forma, os efeitos tóxicos da TFD ficam restritos apenas à região irradiada. Diferentemente da radioterapia, na TFD a morte celular é observada em 4 horas e o tecido danificado é aparente após 24 horas. Nos casos de morte necrótica, os efeitos são observados em alguns dias.

A TFD pode ainda matar a massa tumoral através da destruição dos vasos sanguíneos que a irrigam, promovendo a falta de oxigenação naquela região (isquemia). $\mathrm{A}$ isquemia pode ser alcançada quando é ministrada uma dose excessiva do fotossensibilizador ou de irradiação, de forma contínua e por um longo período (dezenas de minutos). Em ambos os casos, é observada uma rápida diminuição da pressão parcial de $\mathrm{O}_{2}$ da região $\left(\mathrm{pO}_{2}\right)$, que só é 
restabelecida quando a irradiação é interrompida [1]. Dentre os efeitos colaterais observados até o momento, com os fotossensibilizadores comerciais para este fim, é relatada apenas uma alta sensibilidade à radiação solar. Este efeito está associado ao elevado tempo de retenção destes fármacos no organismo. Todavia, fotossensibilizadores de segunda geração, além de serem excretados mais rapidamente também apresentam maior eficiência no tratamento.

\subsection{MECANISMOS DE ATUAÇÃO DOS FOTOSSENSIBILIZADORES}

As propriedades fotoquimicas e fisico-químicas dos agentes fotossensibilizantes como a absorção de luz na intensidade e comprimento de onda adequado, a eficiência na formação de oxigênio singlete, a relação da sua estrutura química com a afinidade a sítios celulares adequados, a baixa toxicidade no escuro e rápida eliminação do corpo são algumas das características que devem ser consideradas no desenvolvimento de fotossensibilizadores para TFD. Estes fatores, associados ao desenvolvimento de fontes luminosas mais eficientes e baratas, fazem da TFD uma modalidade de tratamento que envolve conhecimentos multidisciplinares.

\subsubsection{A FORMAÇÃO DE OXIGÊNIO SINGLETE - ${ }^{1} \mathrm{O}_{2}$}

A excitação do fotossensibilizador por meio da absorção de luz gera espécies com propriedades completamente diferentes daquelas no estado fundamental. Por exemplo, essas espécies tornam-se melhores oxidantes ou redutores e, portanto, mais reativas.

A absorção do fóton leva imediatamente o sensibilizador a um estado de maior energia, denominado estado excitado singlete ( ${ }^{1}$ Sens ${ }^{*}$, figura $2(A)$ ). Esta energia adicional pode ser dissipada por um processo chamado de conversão interna (ci), onde as colisões com as moléculas do solvente desativam o estado excitado termicamente. Outras duas possibilidades são: a emissão de 
um fóton de menor energia ( $h v_{f}$; fluorescência) ou ainda o cruzamento interssistema (cis; inversão de spin). Este último evento produz um estado eletronicamente excitado de maior tempo de vida (triplete; ${ }^{3}$ Sens ${ }^{*}$ ) e portanto com maior probabilidade de transferir energia para espécies receptoras adequadas (sensibilização). Assim, mesmo espécies como $\mathrm{O}_{2}$, com baixas eficiências de absorção de luz devido a uma transição proibida por spin, podem ser excitadas desde que estejam na presença de fotossensibilizadores adequados [14].

As porfirinas e compostos análogos apresentam propriedades fotofisicas adequadas para transferir energia às moléculas de $\mathrm{O}_{2}$ no estado fundamental triplete $\left({ }^{3} \Sigma_{g}\right)$, gerando a espécie singlete excitada $\left({ }^{1} \Delta_{g}\right)$, denominada de oxigênio singlete $\left({ }^{1} \mathrm{O}_{2}\right.$, figura $\left.2(B)\right)$ e que possui uma energia $22,5 \mathrm{kcal} / \mathrm{mol}$ superior ao da molécula no estado fundamental [15].

(A)

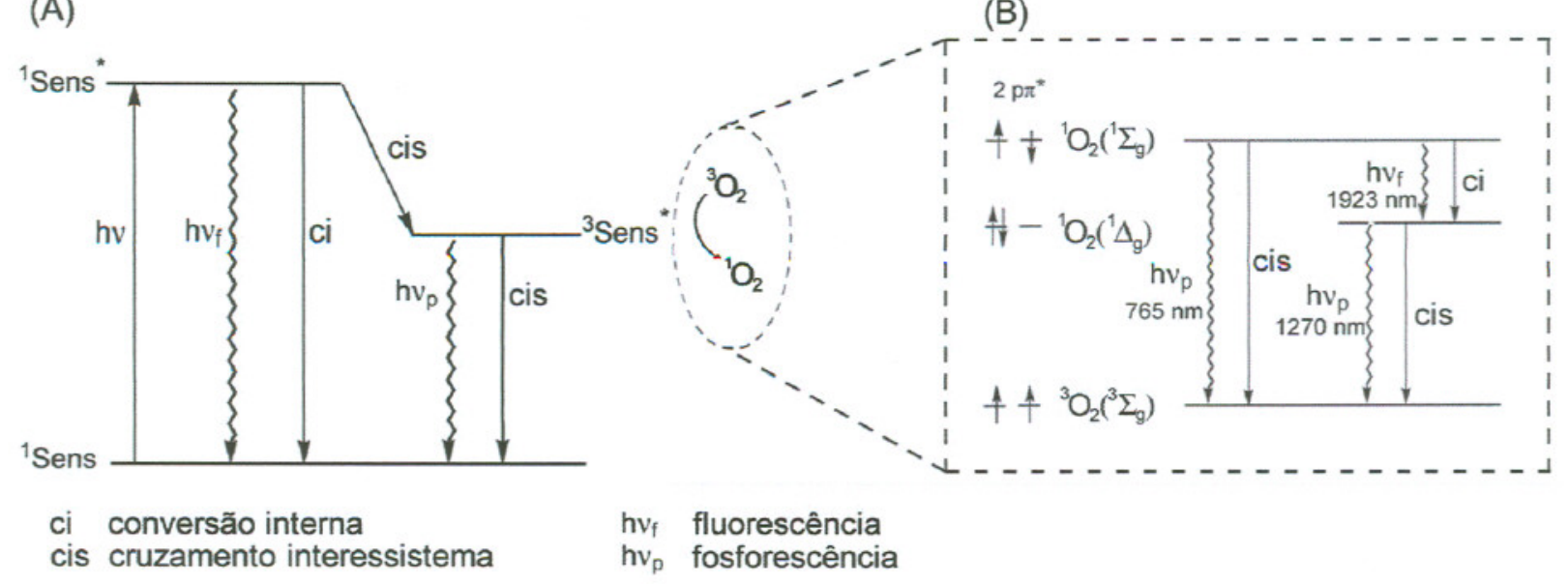

Figura 2: (A) Esquema mostrando os processos eletrônicos envolvidos na desativação dos estados excitados de um sensibilizador. (B) Esquema ilustrando as multiplicidades de spin e as energias dos estados excitados da molécula de oxigênio.

O tempo de vida do ${ }^{1} \mathrm{O}_{2}$ em água é de aproximadamente $2-4 \mu$ s [16]. Entretanto em sistemas celulares, devido aos processos colisionais com as inúmeras espécies citosólicas, este tempo de vida passa a ser estimado em 


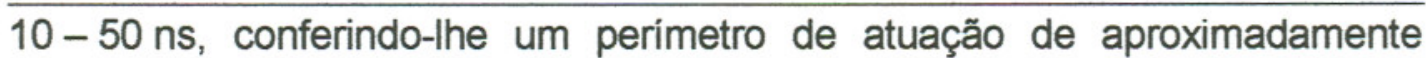
$0,1 \mu \mathrm{m}$. Logo, seus efeitos lesivos possuem eficácia apenas nas proximidades da molécula do fotossensibilizador que está sendo irradiado.

\subsubsection{PRINCIPAIS ALVOS DE ATAQUE DO ${ }^{1} \mathrm{O}_{2}$}

Os principais sítios de reação do oxigênio singlete são aqueles ricos em elétrons, tais como os resíduos de guanina, cadeias laterais de aminoácidos contendo substituintes aromáticos e grupos tiolato ou tioéter, além de ligações duplas de esteróides e lipídeos insaturados. Isso implica, por exemplo, em danos ao DNA, à parede celular, mitocôndrias e lisossomos, comprometendo a integridade celular.

Dois tipos de mecanismos fundamentais [16-18] são reconhecidos como principais atuantes na foto-oxidação induzida por fotossensibilizadores em TFD (figura 3). O primeiro (tipo I), é atribuído à reação do fotossensibilizador no estado excitado triplete $\left({ }^{3}\right.$ Sens $\left.{ }^{*}\right)$ diretamente com o substrato. Esta reação geralmente forma radicais livres [19] e ions radicais (figura 4, (1)) que em seguida, sofrem várias reações subseqüentes (figura 4, (2), (3), (4)), incluindo desde transferência de elétrons para o oxigênio molecular até abstração de hidrogênio de outros substratos.

O mecanismo do tipo II é caracterizado inicialmente pela interação e transferência de energia ou de elétrons do ${ }^{3} \mathrm{Sens}^{*}$ para $\circ \mathrm{O}_{2}$, formando respectivamente $\mathrm{O}^{1} \mathrm{O}_{2}$ ou $\mathrm{O}_{2}{ }^{*-}$ (ion radical superóxido), respectivamente, que oxidam o substrato. Por exemplo, se o substrato for um fosfolipídeo poliinsaturado de membrana (figura $4,(6)$ ), $\circ{ }^{1} \mathrm{O}_{2}$ pode se inserir nas duplas ligações formando hidroperóxidos ( $\mathrm{LOOH}$ ). Os $\mathrm{LOOH}$, formados em ambos os mecanismos, são compostos bastante reativos que desencadeiam sucessivas reações oxidativas em cadeia, sem a necessidade de luz, denominadas peroxidações lipídicas.

Os mecanismos do tipo I e ll são mecanismos oxidativos competitivos e podem ocorrer simultaneamente, dependendo da concentração de $\mathrm{O}_{2}$ e de substrato. A natureza química do fotossensibilizador também influencia este

Fábio Monaro Engelmann

Tese de Doutorado

Química - USP

S - supressor (substrato ou solvente)

Figura 3: Esquema mostrando os dois mecanismos (Tipo I e II) envolvidos na foto-oxidação de um substrato (S), induzida por um sensibilizador no estado excitado triplete ( ${ }^{3}$ Sens $\left.{ }^{*}\right)$. 
3.2 - Mecanismos de Atuação dos Fotossensibilizadores

processo. Por exemplo, fotossensibilizadores carbonilicos, como cetonas e quinonas, com estados triplete $-\pi^{\star}$ apresentam um grande poder em abstrair hidrogênio de moléculas orgânicas. Por outro lado, sensibilizadores com natureza $\pi \pi^{*}$, como fluoresceína e fenotiazina, reagem exclusivamente via formação de ${ }^{1} \mathrm{O}_{2}$.

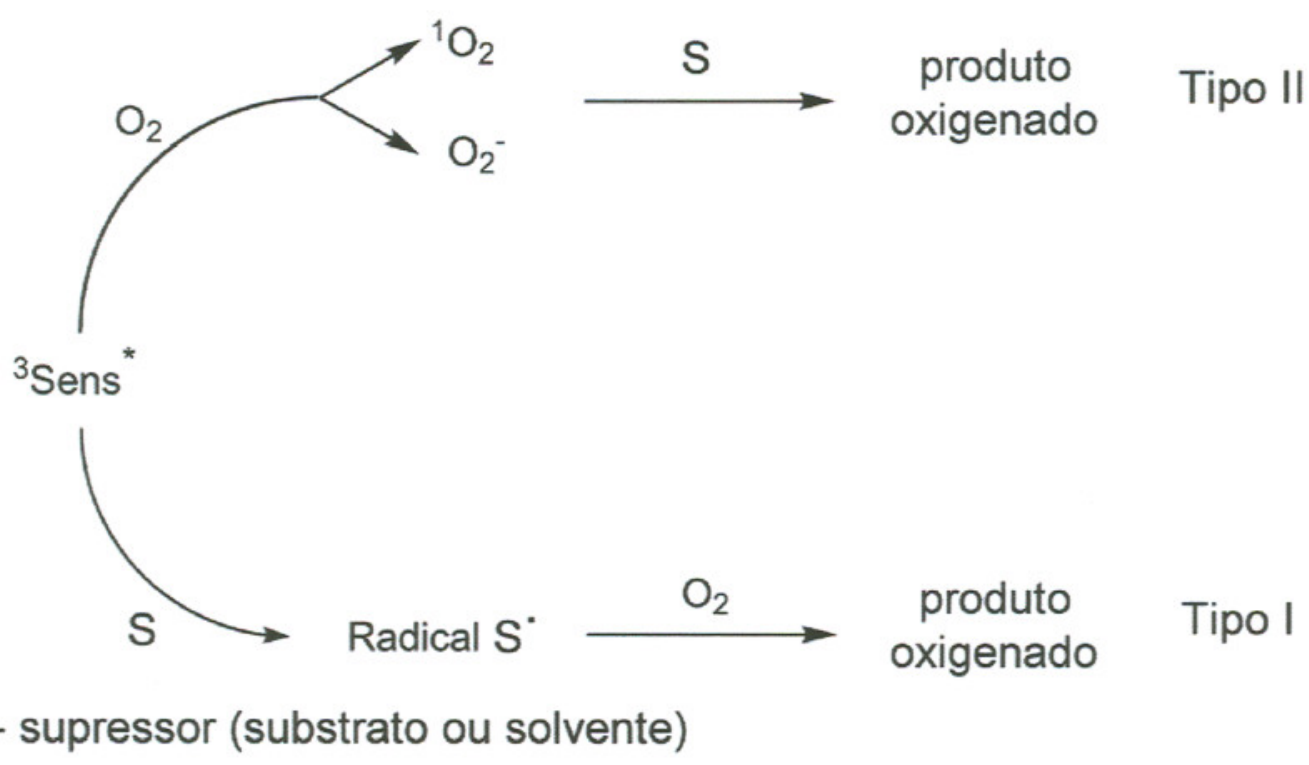

Figura 3: Esquema mostrando os dois mecanismos (Tipo I e II) envolvidos na foto-oxidação de um substrato (S), induzida por um sensibilizador no estado excitado triplete ( ${ }^{3}$ Sens $\left.{ }^{*}\right)$. 
Reações dependentes de luz

Tipo 1

$$
\begin{gathered}
{ }^{3} \text { Sens }^{*}+\mathrm{SH} \rightarrow{ }^{3} \text { Sens } \\
\mathrm{LH}^{-}+\mathrm{S}^{*} \rightarrow \mathrm{L}^{*}+\mathrm{SH} \\
\mathrm{L}^{*}+\mathrm{H}^{+} \mathrm{O}_{2} \rightarrow \mathrm{LOO}^{*} \\
\mathrm{LOO}^{*}+\mathrm{LH} \rightarrow \mathrm{LOOH}+\mathrm{L}^{\cdot}
\end{gathered}
$$

Tipo /

$$
\begin{gathered}
{ }^{3} \text { Sens }{ }^{*}+{ }^{3} \mathrm{O}_{2} \rightarrow{ }^{3} \text { Sens }+{ }^{1} \mathrm{O}_{2} \\
\mathrm{LH}+{ }^{1} \mathrm{O}_{2} \rightarrow \mathrm{LOOH}
\end{gathered}
$$

$$
\begin{gathered}
\mathrm{LOOH}+\mathrm{Fe}^{2+} \rightarrow \mathrm{LO}^{*}+\mathrm{OH}^{-}+\mathrm{Fe}^{3+} \\
\mathrm{LO}^{*}+{ }^{3} \mathrm{O}_{2} \rightarrow \mathrm{OLOO}^{*} \\
\mathrm{OLOO}^{*}+\mathrm{LH} \rightarrow \mathrm{OLOOH}+\mathrm{L}^{\cdot} \\
\mathrm{OLOOH}+\mathrm{Fe}^{2+} \rightarrow \mathrm{OLO}^{*}+\mathrm{OH}^{-}+\mathrm{Fe}^{3+} \\
\mathrm{OLO}^{*}+\mathrm{LH} \rightarrow \mathrm{OLOH}+\mathrm{L}^{\cdot}
\end{gathered}
$$

Reações independentes de luz

Figura 4: Esquema mostrando algumas das possiveis reações envolvidas nos processos de oxidação dependentes (à esquerda) e independentes (à direita) de luz.

Biomoléculas extensamente conjugadas como os carotenóides, os furanóides, vitaminas $E$ ( $\alpha$-tocoferóis) e $C$ (ascorbatos), atuam como supressores químicos do ${ }^{1} \mathrm{O}_{2}$, compondo um mecanismo de proteção contra os efeitos deletérios desta forma reativa de oxigênio [18].

\subsection{IRRADIAÇÃO DO TECIDO ANIMAL}

O tecido animal e os constituintes sangüineos absorvem ou espalham intensamente quase todos os comprimentos de onda da região do visível, sendo que a absorção máxima ocorre no ultravioleta e diminui exponencialmente até 0 infravermelho próximo (figura 5). Por outro lado, a água presente nos tecidos absorve eficientemente acima de $800 \mathrm{~nm}$ [20]. Estes fatores constituem uma das limitações da TFD. Entretanto, na região vermelha do espectro visivel (aproximadamente de 600 a $700 \mathrm{~nm}$ ), a pele torna-se relativamente transparente, permitindo um acesso a tecidos mais 
3.3 - Irradiação do Tecido Animal

profundos da derme. Este fato pode ser evidenciado quando colocamos uma fonte de luz, como uma lanterna, na palma da mão e observamos a região oposta avermelhada. Embora esta transparência não ultrapasse $1 \mathrm{~cm}$ de profundidade, fica claro que o agente fotossensibilizante deve absorver intensamente nesta região, denominada janela fototerapêutica.

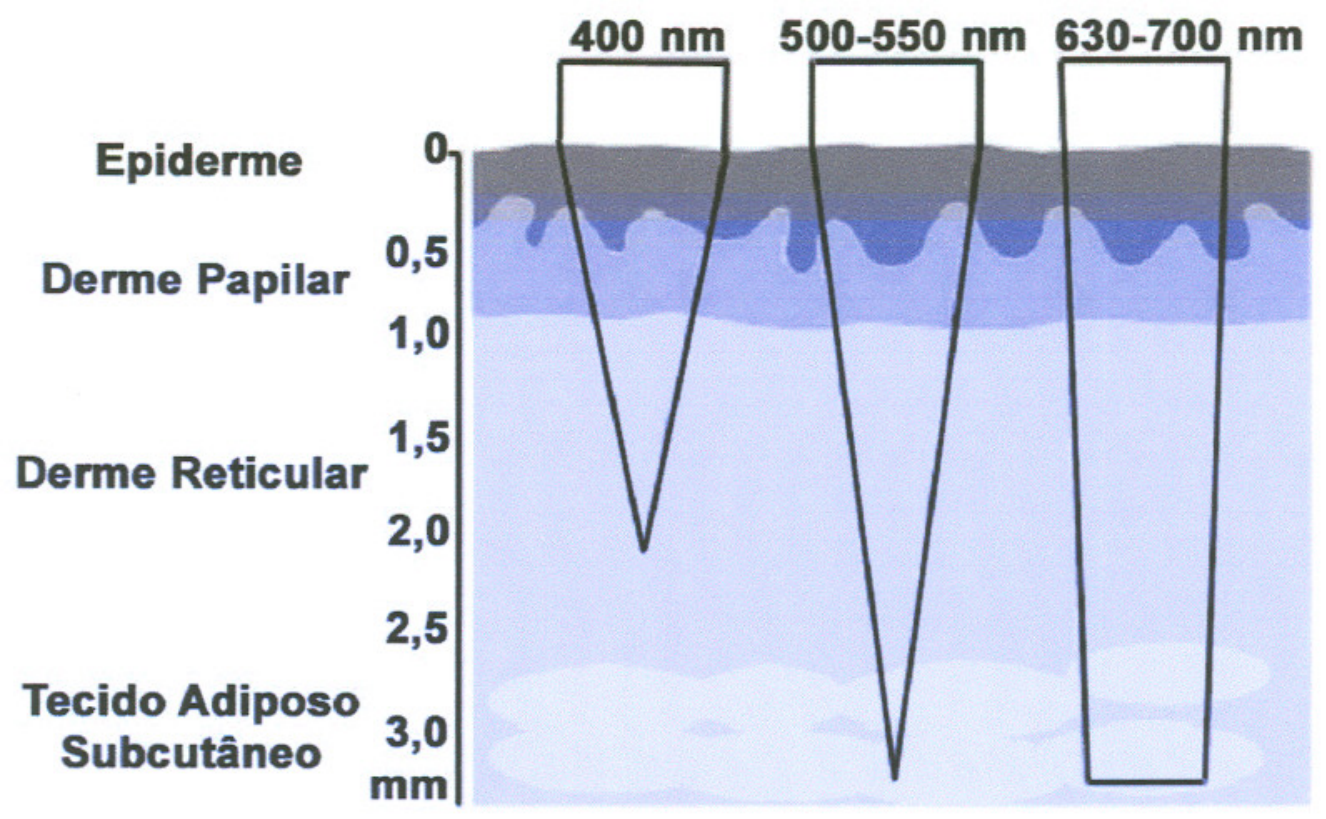

Figura 5: llustração mostrando a relação entre o comprimento de onda de irradiação e sua capacidade de penetração nas camadas da pele.

Os fotossensibilizadores podem ainda matar o tumor de forma indireta através da destruição dos vasos sanguíneos responsáveis pela nutrição e oxigenação deste tecido. 


\subsection{INTERAÇÃO DO FOTOSSENSIBILIZADOR COM O TECIDO}

A interação dos fotossensibilizadores com as células, sua capacidade de permear através de membranas e de retenção, além de suas habilidade em produzir espécies citotóxicas são fatores que definem a atividade fotodinâmica dos mesmos. Contudo, a eficiência de um dado fotossensibilizador in vivo depende de sua interação com os componentes do plasma sanguineo e sua acumulação nos tecidos neoplásicos, bem como sua localização intracelular $[21,22]$. Acredita-se que entre os principais alvos da ação fotodinâmica encontram-se as membranas biológicas. Assim, a atividade fotodinâmica, por exemplo, das porfirinas deve ser determinada em grande parte pelas constantes de associação com as membranas e células [23,24], em relação aos componentes do plasma sanguineo.

Em particular, as mitocôndrias têm demonstrado ser um dos alvos chaves para o desencadeamento de um tipo de morte celular desejado nos tratamentos com TFD, a apoptose $[25,26]$. Neste processo, os danos oxidativos gerados pelos fotossensibilizadores à membrana mitocondrial, acabam por levar à perda de potencial de membrana e ao intumescimento da organela. Nesta etapa há liberação de citocromo-c e outros fatores para o citosol, que ativam uma cascata de enzimas cuja função é preparar a célula para o "suicídio" $[25,27]$. Como resultado, a célula "murcha" sendo removida posteriormente pelo sistema de defesa. A necrose é o outro tipo de morte celular, que ocorre geralmente quando são causados danos oxidativo na membrana celular. Isto pode ocorrer diretamente, quando o corante se encontra fixado próximo da membrana, ou indiretamente, quando o corante danifica inicialmente algum compartimento celular especifico, como os lisossomos e o DNA. Neste caso, os eventos posteriores são caracterizados pelo inchamento da célula, que é sucedido pelo rompimento da membrana citoplasmática e extravasamento dos constituintes celulares. Estes eventos ocorrem em minutos e acabam por danificar o tecido circunvizinho, induzindo uma resposta inflamatória com inchaço e rubor do tecido irradiado.

A determinação do tipo de morte celular parece estar associada ao nível de ATP intracelular. Estudos recentes $[23,28]$, mostraram que a morte é por 
3.4 - Interação do Fotossensibilizador com o Tecido

necrose quando são causados danos mitocondriais em células mantidas à baixa concentração de ATP. Porém, quando os niveis de ATP são mantidos mais elevados, a célula possui condições energéticas suficientes para sintetizar as enzimas necessárias para a apoptose.

A literatura $[26,29]$ reporta que o acúmulo preferencial de corantes catiônicos em células malignas, comparativamente às células sadias, é atribuído ao seu elevado metabolismo celular e principalmente à presença de uma grande quantidade de mitocôndrias. Neste último caso, o gradiente de pH gerado pelo bombeamento de prótons para fora da membrana mitocondrial cria um acúmulo de cargas negativas no interior da organela, gerando um potencial elétrico através da membrana. Este potencial de membrana parece ser responsável pela maior eficiência das mitocôndrias em absorver espécies catiônicas, pois a incorporação é acentuada com o aumento da diferença de potencial intermembrana e desfavorecida quando a membrana é desacoplada [30]. Embora, a presença de carga positiva na estrutura do fotossensibilizador pareça ser essencial para o direcionamento à mitocôndria, a incorporação também é fortemente dependente de seu grau de lipofilicidade [26].

Neste sentido, Zimmermann [23] mostrou que porfirinas carregadas como a meso-tetra(4- $\mathrm{N}$-metilpiridil)porfirina $\left(4 \mathrm{P}_{4}(1)\right.$; carga $4+$; figura 1$)$, mesotetra(4-sulfonatofenil)porfirina (TPPS; carga 4-), e meso-tetra(4- $N$ decilpiridil)porfirina $\left(4 \mathrm{P}_{4}(10)\right.$; carga $\left.4+\right)$ apresentaram diferenças significativas na resposta fotodinâmica quando irradiadas em meio de cultura de células

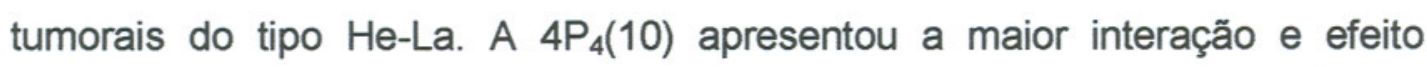
fototóxico (1 hora de incubação e 15 minutos de irradiação à $25 \mathrm{~mW} / \mathrm{cm}^{2}$, $\lambda_{\text {exc }}>425 \mathrm{~nm}$ ) nas células tumorais que as $4 \mathrm{P}_{4}(1)$ e TPPS. $A$ análise dos compartimentos celulares demonstrou um maior acúmulo da $4 \mathrm{P}_{4}(10)$ em mitocôndrias. Além disso, após a irradiação a matriz mitocondrial foi completamente destruída, enquanto que para as outras duas porfirinas ela manteve-se inalterada, mesmo com um tempo de irradiação maior (45 minutos). 
3.4 - Interação do Fotossensibilizador com o Tecido

Ricchelli [31] recentemente mostrou que a ligação destas porfirinas tetracatiônicas com células de fibrosarcoma humano (HT1080) e sua fotoinativação são proporcionais ao comprimento das cadeias alifáticas saturadas periféricas, atingindo uma eficiência máxima com 14 átomos de carbono $\left(4 \mathrm{P}_{4}(14)\right)$. Neste caso, o efeito está diretamente associado à partição do corante na membrana celular. A utilização de cadeias alifáticas excessivamente grandes, por exemplo $4 \mathrm{P}_{4}(22)$, favorecem os efeitos de agregação, aumentando a toxicidade no escuro e diminuem a capacidade de ligação. Além disso, seus resultados mostraram, curiosamente, que os fotossensibilizadores estudados $\left(4 \mathrm{P}_{4}(6), 4 \mathrm{P}_{4}(14)\right.$ e $\left.4 \mathrm{P}_{4}(22)\right)$ se concentraram exclusivamente nos lisossomos e nos compartimentos celulares ácidos ao invés de se ligarem às mitocôndrias.

Esta diferença entre os resultados de Zimmermann e Ricchelli sugere que fotossensibilizadores com lipofilicidade demasiadamente elevada podem ligar-se quase que irreversivelmente à membrana celular. Neste caso, a absorção deve ocorrer por fagocitose do corante, que serão provavelmente digeridas pelos lisossomos.

Deste modo, inúmeros estudos envolvendo porfirinas e células ou mitocôndrias têm sido publicados. Jori [32] por exemplo, mostrou que a série das porfirinas catiônicas contendo 2, 2, 3 e 4 ions $N$-4-metilpiridinio (figura 1) não apresenta grandes variações de penetração em bactérias gram-positivas, gram-negativas e em e-coli. Todavia, a parede celular bacteriana possui características estruturais muito distintas das membranas celulares de eucariotos, sendo menos susceptível à penetração de fármacos.

O estado de agregação, o tipo e distribuição de cargas, a polaridade, a estereoquímica e $\circ$ tamanho dos substituintes são importantes fatores, que determinam a distribuição dos fotossensibilizadores pelo organismo. Acreditase que as espécies hidrofilicas são em geral absorvidas por mecanismos de pinocitose e se acumulam nos grânulos extra-celulares, como no caso das aluminio ftalocianinas sulfonadas [33]. Espécies hidrofóbicas apresentam uma maior facilidade de penetrar na parede celular, e quando encapsuladas tendem 
3.4 - Interação do Fotossensibilizador com o Tecido

a se ligar aos lipídios de baixa densidade (LDL), acumulando-se preferencialmente na membrana lisossomal.

Alguns dos agentes fototerapêuticos são bastante eficientes podendo ser administrados ao paciente em soluções mais diluídas, diminuindo os riscos de intoxicação $[6,34,35]$. Recentemente tornou-se disponivel no mercado um derivado porfirínico (verteporfirina) [36-38] chamado comercialmente de Visudyne $^{\circledR}$. Este é o primeiro e único fototerápico comercial para pacientes que sofrem de degeneração macular da retina, que consiste no crescimento anormal de vasos sanguíneos sobre o centro da retina (mácula) [6]. A evolução dessa anomalia geralmente leva o paciente a perda total da visão. A droga, encapsulada em vesículas lipoproteícas de baixa densidade (LDL), é administrada diretamente na corrente sanguinea. A irradiação é feita com um laser vermelho de $689 \mathrm{~nm}$ por 83 segundos, 15 minutos após a injeção.

O tempo necessário para que ocorra a partição do sensibilizador é outro fator importante. Estudos realizados com um derivado de hemato e mesoporfinina [39] sugerem que a partição das mesmas da fase aquosa para lipossomos ou membranas celulares ocorre na faixa de 10 a 60 minutos. Por outro lado, os estudos de Csik et alli [40] e Kuzelova et alli [41] mostraram que a incorporação de porfirinas em células ocorre por meio de um processo bifásico. Inicialmente, ocorre a rápida associação da porfirina com a superficie externa da membrana citoplasmática, seguido da migração da mesma para sítios intracelulares. A segunda fase é relativamente lenta e independente da concentração de moléculas de lipídios, como esperado para processos dessa natureza.

Além disso, a localização dos sensibilizadores pode variar em função do tempo. Rück e colaboradores [42] estudaram a interação de ftalocianinas hidrofilicas e hidrofóbicas encapsuladas em lipossomos com tumores de bexiga e de pele de ratos. Os sensibilizadores foram injetados e a irradiação $(672 \mathrm{~nm})$ foi efetuada após 24 horas, acompanhando-se a fluorescência do tecido tumoral a cada 30 segundos. Verificou-se, assim, que a fluorescência varia significativamente em função do tempo, sendo o comportamento das espécies 
3.5 - Tipos de Fotossensibilizadores

hidrofilicas e hidrofóficas bem diferentes uns dos outros. $O$ deslocamento do sensibilizador não ocorre apenas durante a incubação, mas também pode ocorrer durante a irradiação [43].

\subsection{TIPOS DE FOTOSSENSIBILIZADORES}

Nos últimos 10 anos, inúmeros sensibilizadores têm sido desenvolvidos com a intenção de serem aplicados em TFD. Neste contexto, as porfirinas e seus derivados compreendem as estruturas mais extensamente estudadas, em parte devido a sua maior biocompatibilidade. Como exemplo, pode-se citar o Photofrin $^{\circledR}$, que é constituído de uma mistura de várias formas de porfirinas monoméricas e oligoméricas. Este composto foi o primeiro fotossensibilizador aprovado pelo FDA (Food and Drug Administration dos EUA) para tratamento de vários tipos de cânceres [34]. Todavia, além da baixa absorção em $630 \mathrm{~nm}$, o Photofrin ${ }^{\circledR}$ também possui a desvantagem de apresentar um elevado tempo de retenção no organismo. A conseqüência é uma acentuada fotossensibilidade à luz solar pelo paciente a qual pode se prolongar por até 12 semanas.

Idealmente, um fotossensibilizador para TFD deve apresentar elevada absorção na região de 650 a $750 \mathrm{~nm}$, eficiente rendimento quântico de formação de ${ }^{1} \mathrm{O}_{2}$, baixa reatividade no escuro, além de um elevado acúmulo no tecido tumoral. Para isto as propriedades fotofísicas e estruturais devem ser adequadamente ajustadas a fim de proporcionar a maior eficiência possivel.

Neste sentido, as clorinas constituem uma segunda geração de fotossensibilizadores que são mais eficientes na absorção de luz na região fototerapêutica do espectro e na sua distribuição nos tecidos cancerígenos. Além disso, estas estruturas são fotoquimicamente mais instáveis que as porfirinas, podendo ser eliminadas mais rapidamente do organismo.

A tetra(m-hidroxifenil)clorina (m-THPC, Foscan $\left.{ }^{\circledR}\right)$ [1], por exemplo, apresenta uma absortividade molar $\sim 20$ vezes superior ao 
Photofrin $^{\circledast}\left(2,2 \times 10^{4} \mathrm{M}^{-1} \cdot \mathrm{cm}^{-1}\right.$ em $652 \mathrm{~nm}$ e $1,2 \times 10^{3} \mathrm{M}^{-1} \cdot \mathrm{cm}^{-1}$ em $630 \mathrm{~nm}$, respectivamente), sem alterações significativas no $\phi_{\Delta}(0,90)$. Além disso, o $m$ THPC é mais hidrofóbico [6], o que permite uma maior incorporação no tecido celular. Seu tempo de retenção é praticamente a metade do Photofrin ${ }^{\circledR}$ (de 3 a 6 semanas), mas ainda assim é considerado um periodo muito longo.

Vários outros fotossensibilizadores com absorção similar ou mais intensa na região vermelha do espectro têm sido preparados e estudados. Como exemplo, pode-se citar as ftalocianinas, purpurinas, texafirinas, entre outras [35].

Em especial, as porfirinas invertidas ou N-confusas (figura 6), sintetizadas por Furuta et alli [44], constituem uma nova classe de compostos de interesse em TFD. Estas espécies diferem das porfirinas convencionais por exibirem um e dois nitrogênios pirrólicos voltados para fora do anel porfirínico, sendo denominadas de porfirina $\mathrm{N}$-confusa e duplamente $\mathrm{N}$-confusa $[45,46]$, respectivamente. Estas estruturas permitem acomodar metais de transição em estados de oxidação anormalmente elevados como $\mathrm{Ag}^{3+}$ e $\mathrm{Cu}^{3+}[47,48]$. No caso da porfirina duplamente $\mathrm{N}$-confusa, os dois nitrogênios pirrólicos externos ao anel são susceptiveis tanto a protonação, pela adição de vapor de $\mathrm{HCl}$, quanto a desprotonação, pela reação com vapor de $\mathrm{NH}_{3}$ [49]. Este interessante comportamento possibilita a modulação das propriedades espectroscópicas desses compostos por simples alteração no pH do meio. 
<smiles>BrCC1=C(Br)C2=CC=C(NC(=C(Br)c3ccccc3)C=N1)C(Br)=C1C=CC(=C(Br)c3ccc([nH]3)N1)C2</smiles>

Porfirina N-confusa<smiles>BrCC1=C(Br)C2=CC=C(NC(=C(Br)c3ccccc3)C=N1)C(Br)=C1C=CC(=C(Br)c3ccc([nH]3)N1)C2</smiles>

Porfirina Duplamente $\mathrm{N}$-confusa

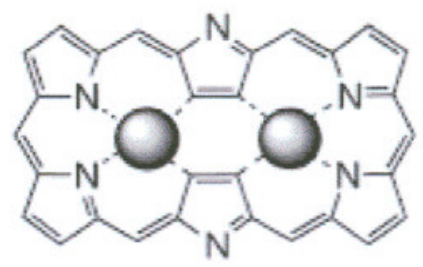

Hexafirina

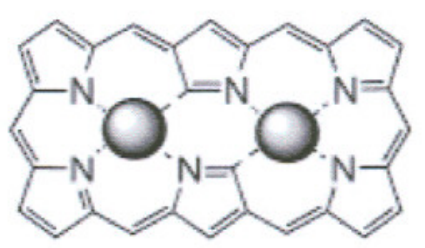

Hexafirina Duplamente N-confusa

Figura 6: Estruturas moleculares das porfirinas $\mathrm{N}$-confusa e cis duplamente $\mathrm{N}$ confusa e da hexafirina e hexafirina duplamente $\mathrm{N}$-confusa nas formas metaladas.

O espectro eletrônico da porfirina $\mathrm{N}$-confusa apresenta bandas de baixa intensidade na região de 550 a $750 \mathrm{~nm}$, quando comparadas com a duplamente $\mathrm{N}$-confusa $\left(10^{4} \mathrm{M}^{-1} \cdot \mathrm{cm}^{-1} \mathrm{em} 620 \mathrm{~nm}\right.$; acetonitrila). Neste caso, a metalação do anel ainda promove um acréscimo de 2 vezes na intensidade das bandas desta região. Todavia, a coordenação de metais de transição pode aumentar a reatividade do anel porfirínico. Por exemplo, o complexo de $\mathrm{Cu}$ (III) da porfirina $\mathrm{N}$-confusa (figura $7 \mathrm{~A}$ ) pode sofrer oxidação durante refluxo em tolueno [50]. Em atmosfera inerte de nitrogênio ou argônio, não é observado decomposição da amostra sendo o mecanismo de oxidação consistente com dois ataques sucessivos do $\mathrm{O}_{2}$ à duas posições meso do anel (figura 7B). 


\section{Capitulo 3: Introdução}

3.5 - Tipos de Fotossensibilizadores

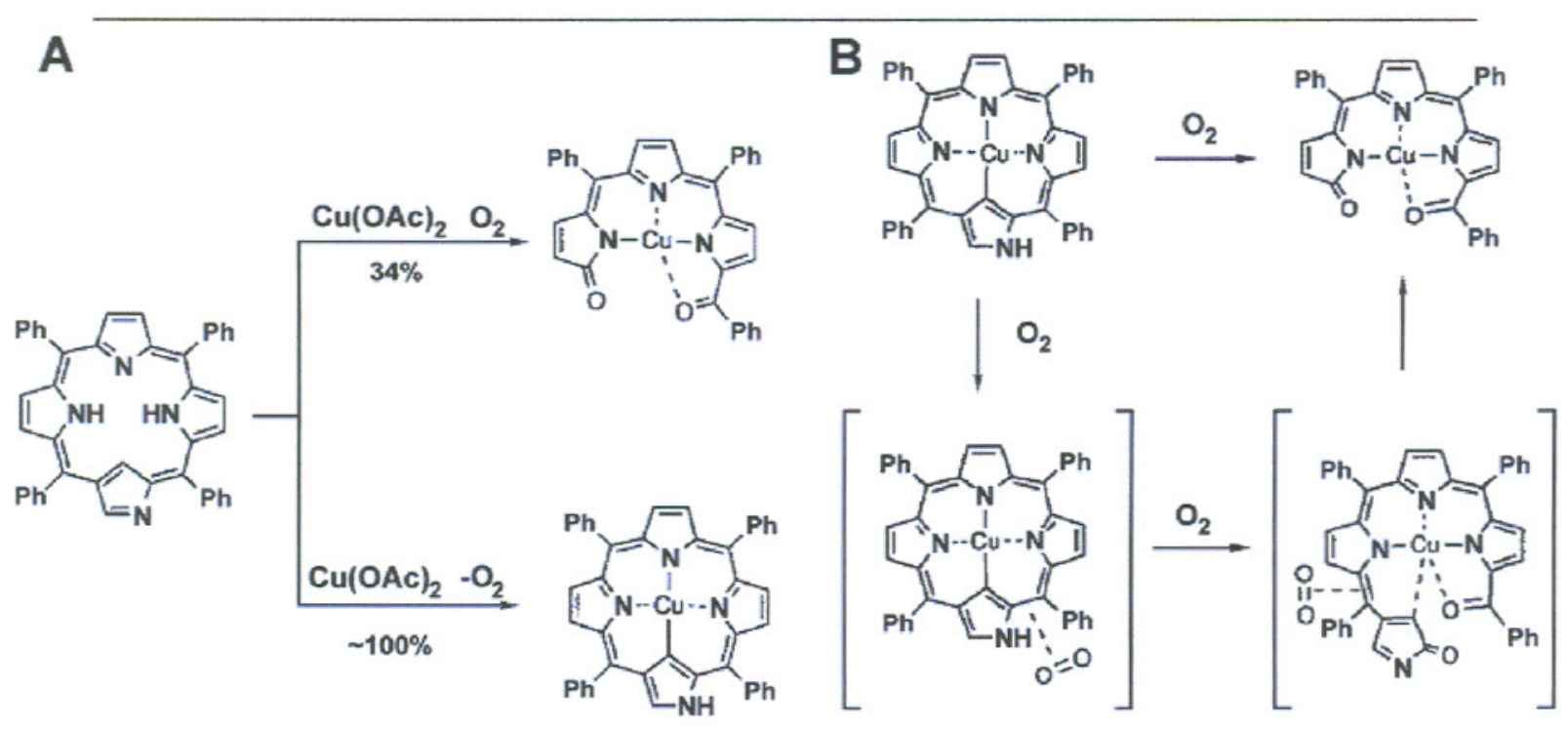

Figura 7: (A) Esquema mostrando a oxidação do anel $\mathrm{N}$-confuso, durante a reação com $\mathrm{Cu}(\mathrm{II})$, que ocorre somente na presença de $\mathrm{O}_{2}$. (B) Esquema mecanístico mostrando as possiveis etapas do ataque do $\mathrm{O}_{2}$ ao anel $\mathrm{N}$ confuso.

$\mathrm{Na}$ literatura não foram encontrados relatos envolvendo os aspectos fotoquímicos para aplicação em TFD desta classe de compostos. De modo que um estudo criterioso da fotoquímica deste sistema foi desenvolvido durante este doutorado. Os resultados renderam dois artigos [51,52] em revistas cientificas internacionais e serão discutidos adiante, na parte experimental.

As dioxohexafirinas duplamente $\mathrm{N}$-confusas constituem outra classe de compostos com propriedades espectroscópicas interessantes. Estas estruturas também foram inicialmente sintetizadas por Furuta et all [53], e apresentam dois anéis porfirínicos convencionais aglutinados que podem acomodar até dois ions metálicos. A absortividade molar do complexo contendo dois átomos de níquel é bastante elevada em solução de acetonitrila $\left(5 \times 10^{4} \mathrm{M}^{-1} \cdot \mathrm{cm}^{-1}\right.$, em $610 \mathrm{~nm})$.

Nossos resultados preliminares mostraram que tanto o complexo níquel como o de cobre são espécies fotoquimicamente bastante estáveis. Neste caso, a irradiação ( $40 \mathrm{~mW}$ em $630 \mathrm{~nm}$ ou $25 \mathrm{~mW}$ em $532 \mathrm{~nm}$ ) prolongada de 
uma solução em acetonitrila saturadas com $\mathrm{O}_{2}$ não causou variações nas bandas de absorção dos compostos. Além disso, aqueles compostos não são luminescentes e não atuam como fotossensibilizadores, não tendo sido detectado formação de ${ }^{1} \mathrm{O}_{2}$ quando irradiadas com luz visível. Estes resultados mostram que embora estas dioxohexafirinas duplamente $N$-confusas apresentem alta absorção na região fototerapêutica, elas não são viáveis para aplicação em TFD.

\subsection{INTERCALAÇÃO AO DNA}

Dentre os sensibilizadores, as porfirinas catiônicas são consideradas compostos bi-funcionais, pois ligam-se fortemente ao DNA modificando-o fotodinamicamente por meio de um mecanismo similar ao de drogas anticâncer como a bleomicina e daunomicina [54], ou seja, promovem a clivagem da cadeia. Três modos principais de interação entre as porfirinas catiônicas e DNA são atualmente aceitos: uma intercalativa e duas de natureza preponderantemente eletrostática, envolvendo ligações à parte externa da cadeia [55,56]. Uma delas se refere à ligação eletrostática aos grupos fosfato e ao "minor groove", enquanto que o segundo modo se refere à formação de pilhas de moléculas de porfirina ("stacking") na parte externa da dupla hélice.

As porfirinas catiônicas meso-substituídas, geralmente tem grupos relativamente volumosos protegendo o anel porfirínico planar, fazendo com que distorções relativamente grandes ocorram no processo de intercalação [57]. Assim, verificou-se que o modo de interação entre porfirina e DNA depende do tamanho e da posição dos substituintes [58,59]. Mas, estudos recentes utilizando porfirinas com substituintes de tamanhos similares sugeriram que os efeitos eletrônicos [60] são mais importantes na determinação do modo de interação. De fato, a estrutura eletrônica parece definir inclusive a tendência de associação das porfirinas e a interação com o DNA formando pilhas. Além disso, a presença de ligantes axiais [57,61] coordenados ao íon metálico central também influencia o modo de interação. 
Assim, a $4 \mathrm{P}_{4} \mathrm{Me}$ base livre e derivados como $\mathrm{Zn}-4 \mathrm{P}_{4} \mathrm{Me}$ e $\mathrm{Cu}-4 \mathrm{P}_{4} \mathrm{Me}$, que não apresentam ligantes axiais, intercalam-se no DNA. Em contraste, metaloporfirinas com ligantes axiais como Co-4 $\mathrm{P}_{4} \mathrm{Me}$ e $\mathrm{Mn}-4 \mathrm{P}_{4} \mathrm{Me}$ se ligam ao exterior da dupla hélice. O principal sítio de intercalação foi determinado como sendo o degrau contendo um par CG. Por outro lado, oligonucleotídeos contendo pares AT favorecem a ligação à parte externa.

Apesar dos derivados meso-substituídos de dimetilpirazólio $\left(\mathrm{H}_{2}\right.$ TDMPzP) e dimetilimidazólio $\left(\mathrm{H}_{2}\right.$-TDImP) serem semelhantes, eles se ligam diferentemente ao DNA [62]. Assim, o primeiro se intercala, enquanto que o segundo se liga externamente ao "minor groove". Essa diferença foi atribuida ao impedimento estérico dos grupos metila nas posições $1 \mathrm{~N}$ e $3 \mathrm{~N}$ do anel, em relação às posições $1 N$ e $2 N$ (figura 8 ). Efeito semelhante foi observado no caso da meso-tetrakis(2-N-metilpiridinio)porfirina. Além disso, verificou-se que a intercalação do $\mathrm{H}_{2}$-TDMPzP é entalpicamente dirigida, enquanto que da $4 \mathrm{P}_{4} \mathrm{Me}$ é entropicamente dirigida. Esse comportamento foi atribuida aos efeitos eletrônicos, principalmente à menor densidade eletrônica no anel porfirínico da primeira.
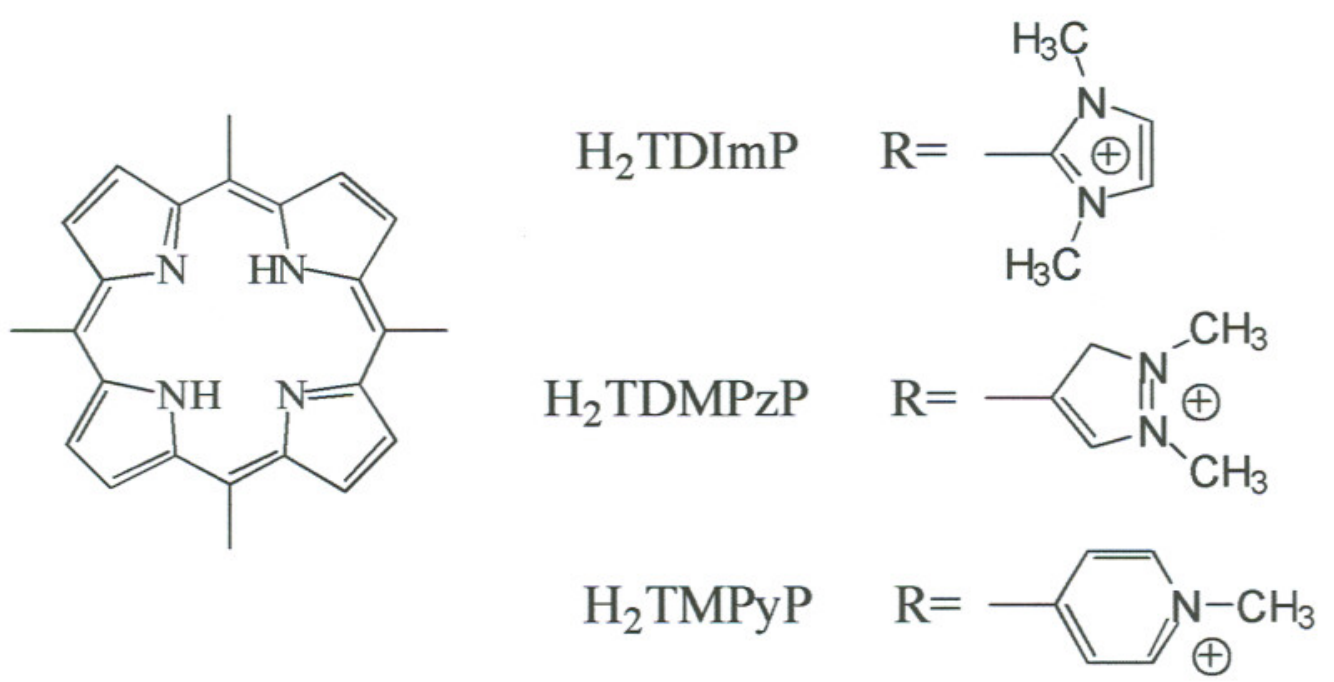

Figura 8: Estruturas das meso-dimetilpirazólio $\left(\mathrm{H}_{2}-\mathrm{TDMPzP}\right)$, mesodimetilimidazólio $\left(\mathrm{H}_{2}\right.$-TDImP) e meso-tetra( $\mathrm{N}$-4-metilpiridinio) $\quad\left(4 \mathrm{P}_{4} \mathrm{Me}\right)$ porfirinas. 
Da mesma maneira que as porfirinas, vários estudos tem demonstrado que $\left[R u(p h e n)_{2} \mathrm{dppz}\right]^{2+}$ interage com o DNA de forma intercalativa [63]. $O$ ligante dppz (dipiridofenazina, figura 9) é capaz de se inserir entre as bases nucléicas da dupla-hélice do DNA, fazendo com que haja uma interação relativamente forte entre as nuvens $\pi$ das bases nucléicas e do dppz. Forma semelhante de interação parece ocorrer no caso dos complexos [Ru(phen) $)_{3}{ }^{2+}$ e $\left[R u(\text { bipy })_{3}\right]^{2+}$, todavia sua intercalação com as bases nucleicas não é tão eficiente como no caso anterior, pois os ligantes phen e bipy [64] não permitem o mesmo grau de penetração. Assim para essas duas espécies a interação proposta é do tipo quasi-intercalativa ou semi-intercalativa (figura 10). De fato, existem várias controvérsias a respeito e atualmente a idéia de que os dois últimos complexos de rutênio interagem preferencialmente pelo modo eletrostático é dominante $[64,65]$.

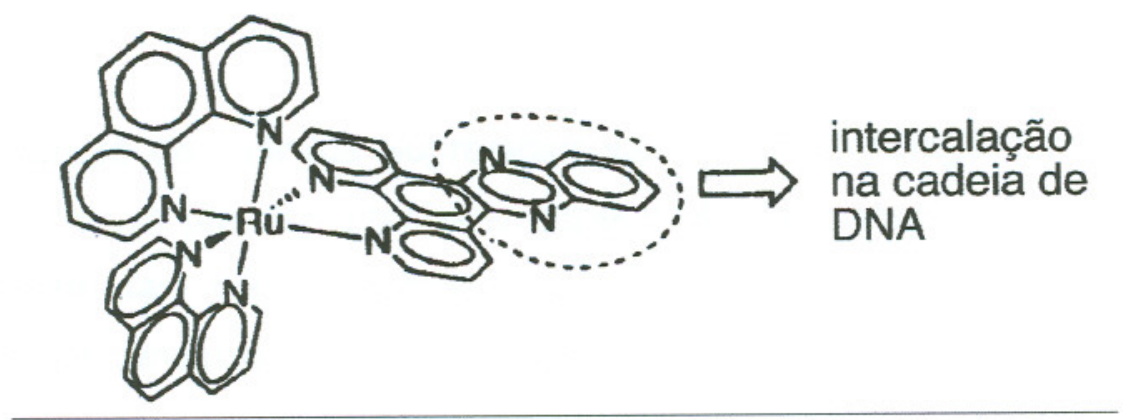

Figura 9: Estrutura da $\left[\mathrm{Ru}(\mathrm{phen})_{2} \mathrm{ddpz}\right]^{2+}$ mostrando a parte do ligante dppz susceptivel de intercalação (círculo pontilhado) e a direção de sua intercalação com o DNA. 


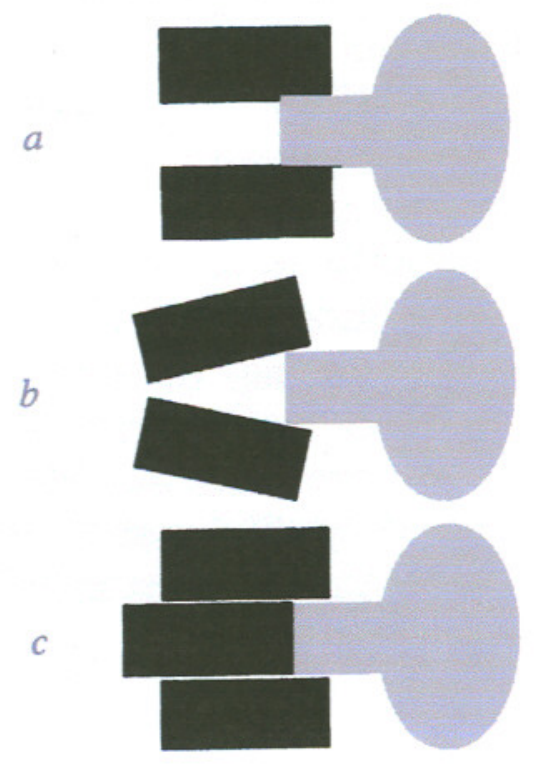

Figura 10: Esquemas mostrando os modos de intercalação (a), semiintercalação (b) e quasi-intercalação (c) de sensibilizadores à dupla hélice do DNA.

O Grupo de Quimica Supramolecular \& Nanotecnologia tem como um de seus objetivos projetar e preparar supermoléculas com novas propriedades de interesse, tais como separação de cargas fotoinduzida, essencial nos processos de conversão de energia luminosa em energia quimica e/ou elétrica; transferência de energia (efeito antena); reconhecimento molecular; além de propriedades redox e catalíticas. Em particular, o Grupo foi um dos precursores do uso da química de coordenação para "montar" controladamente as espécies de interesse para gerar supermoléculas e estruturas supramoleculares $[66,67]$ por meio de ligação coordenada metal-ligante.

Em particular foram realizados estudos com o intuito de se verificar a interação e as propriedades fotodinâmicas [66,67] de meso-(4-piridil)porfirinas coordenadas a quatro grupos $\left[R u(\text { bipy })_{2} C\right]^{+}, 4 \mathrm{P}_{4} R u$, na presença de ct-DNA (calf-thymus DNA). Nessas porfirinas supermoleculares, os complexos de rutênio bipiridina são grupos polares que podem atuar como sítios de interação com a cadeia de DNA e nucleotídeos [58]. Ao mesmo tempo, podem dificultar 
3.6 - Intercalação ao DNA

ou inibir a intercalação dessas espécies devido ao efeito estérico desses substituintes volumosos.

A interação de $4 \mathrm{P}_{4} \mathrm{Ru}$ com DNA provoca mudanças significativas nos espectros de absorção e emissão, num processo em dois estágios [68]. Quando as concentrações relativas de DNA são baixas a interação é predominantemente de natureza eletrostática, mas o modo intercalativo passa a predominar quando a concentração relativa de DNA aumenta. As constantes de equilibrio calculadas para os processos 1 e 2 , foram iguais a $K_{1}=1,5 \times 10^{5} \mathrm{e}$ $\mathrm{K}_{2}=2,5 \times 10^{4} \mathrm{~mol}^{-1} \cdot \mathrm{dm}^{3}$. A Zn-4P $\mathrm{P}_{4} \mathrm{Ru}$ apresentou comportamento similar [68] durante a titulação com DNA, sendo as constantes de equilibrio estimadas em $\mathrm{K}_{1}=5,0 \times 10^{5}$ e $\mathrm{K}_{2}=3,0 \times 10^{4} \mathrm{~mol}^{-1} \cdot \mathrm{dm}^{3}$. Esses resultados sugerem que $\mathrm{Zn}$ $4 \mathrm{P}_{4} \mathrm{Ru}$ interage mais fortemente via mecanismo intercalativo (ou coordenativo), mantendo-se praticamente inalterada a força da interação eletrostática.

Também, foram realizados experimentos de foto-oxidação utilizando dGuo como composto modelo e $4 \mathrm{P}_{4} \mathrm{Ru}$ e $\mathrm{Zn}-4 \mathrm{P}_{4} \mathrm{Ru}$ como fotossensibilizadores, monitorando-se as concentrações de oxazolona, 4-OH-8oxodGuo e 8-oxodGuo (figura 11). Ambos induzem a formação destes dois últimos fotoprodutos [66] em quantidades relativas muito maiores que de oxazolona, indicando que ambos atuam preferencialmente pelo mecanismo do tipo II. Em particular, $\mathrm{Zn}_{4} 4 \mathrm{P}_{4} \mathrm{Ru}$ é um fotossensibilizador que atua quase que exclusivamente pelo mecanismo do tipo II, sendo a relação tipo II/tipo I muito superior ao do padrão azul de metileno. Uma evidência direta desse fato foi obtida medindo-se a fosforescência do oxigênio singlete em $1270 \mathrm{~nm}$, em acetonitrila. 


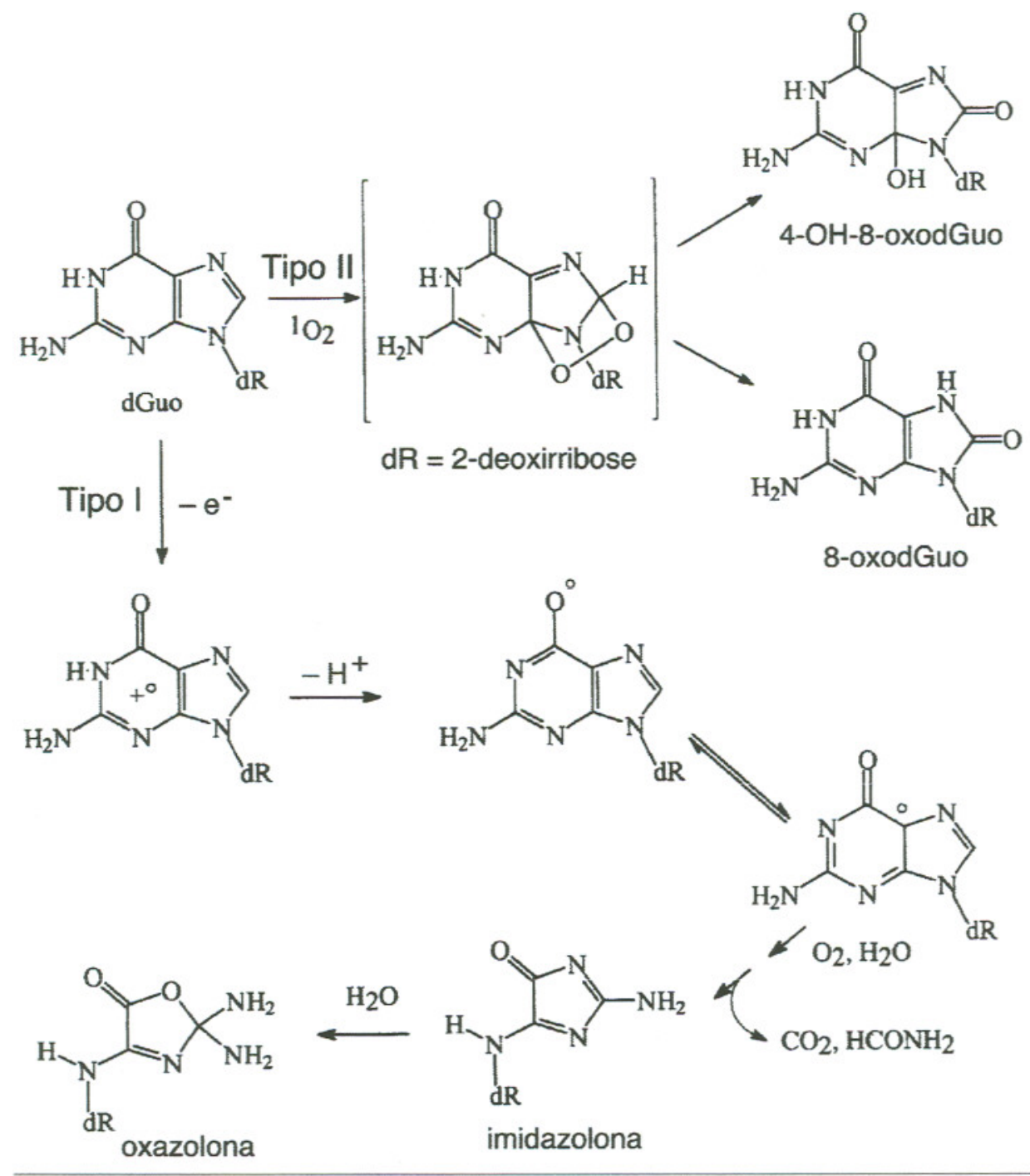

Figura 11: Esquema mostrando a formação dos fotoprodutos da reação de dGuo pelos mecanismos do tipo I e ll.

$\mathrm{Na}$ presente tese foi realizado o estudo sistemático do efeito da substituição de grupos fenila por $\left[\mathrm{Ru}(\text { bipy })_{2} \mathrm{Cl}(\mathrm{py})\right]^{+}$ou grupos $\mathrm{N}$-metilpiridínio nas posições meso do anel porfirínico [69], sobre as propriedades fotodinâmicas. Em particular, foi inequivocamente demonstrado a importância da estereoquimica e distribuição de grupos lipofilicos e hidrofilicos em quatro séries de porfirinas catiônicas sobre a força de interação com mitocôndrias, lipossomos, e células cancerigenas. 


\section{EQUIPAMENTOS E MÉTODOS}

As porfirinas cis duplamente $\mathrm{N}$-confusas base livre $\left(\mathrm{H}_{2} \mathrm{~N}_{2} \mathrm{CP}\right)$ e os respectivos complexos de prata $\left(\mathrm{AgHN}_{2} \mathrm{CP}\right)$ e de cobre $\left(\mathrm{CuHN}_{2} \mathrm{CP}\right)$ foram fornecidos pelo grupo do prof. Furuta [47], da Universidade de Kyoto - Japão. Um amplo estudo abrangendo os aspectos fotofísicos e fotoquímicos foi desenvolvido tanto para as formas neutras como para as espécies protonadas e desprotonadas. Neste caso, foram determinados os tempos de vida do estado $T_{1}, 0$ espectro do transiente, de fluorescência e $\phi_{\Delta}$. Além de uma extensa investigação sobre a estabilidade fotoquímica destas amostras.

No caso das meso-porfirinas catiônicas, o enfoque dos experimentos foi direcionado para o estudo da atividade fotodinâmica em sistemas biológicos. Foram realizados estudos de interações e danos foto-oxidativos com eritrócitos, mitocôndrias e células cancerígenas, sendo os resultados comparados com os obtidos com sistemas modelo de lipossomos e correlacionados com os coeficientes de partição daqueles fotossensibilizadores.

A seguir serão descritos os procedimentos e ou técnicas empregadas nos estudos realizados com as 29 espécies porfirínicas utilizadas como fotossensibilizadores.

\subsection{ESPECTROS DE ${ }^{1} H-R M N$ E COSY}

Os espectros de ressonância magnética nuclear de prótons unidimensional ( $\left.{ }^{1} \mathrm{H}-\mathrm{RMN}\right)$ e bidimensional (COSY) foram obtidos em um espectrofotômetro Varian $300 \mathrm{MHz}$, modelo INOVA 1, da central analítica do IQ-USP. A interpretação foi feita com base nos estudos realizados por Fleischer [70] e por Meng [71]. Os espectros das séries 3S e 4S foram obtidos em $\mathrm{CCl}_{3} \mathrm{D}$, enquanto que os espectros das séries $3 \mathrm{SMe}$ e $4 \mathrm{SMe}$ foram coletados em acetona- $d_{6}$ e DMSO- $d_{6}$. 


\subsection{ESPECTROS ELETRÓNICOS}

Os espectros eletrônicos foram obtidos num espectrofotômetro HP8453A de varredura rápida, de matriz de diodos (na faixa de 190 a $1100 \mathrm{~nm}$ ). $\mathrm{O}$ aparelho também possui um módulo cinético que permite obter espectros com uma resolução temporal máxima de 0,5 segundos entre as medidas.

\subsection{CINÉTICA DE DECOMPOSIÇÃO}

Este experimento foi realizado particularmente no caso das porfirinas cis duplamente $\mathrm{N}$-confusas, $\mathrm{H}_{2} \mathrm{~N}_{2} \mathrm{CP}, \mathrm{AgHN}_{2} \mathrm{CP}$ e CuHN $\mathrm{N}_{2} \mathrm{CP}$. A cinética de fotodecomposição foi determinada acompanhando-se a evolução temporal dos espectros eletrônicos das amostras sob constante irradiação e agitação com barra magnética. Para isto, a leitura dos espectros eletrônicos foi realizada utilizando-se o módulo cinético do espectrofotômetro. A irradiação da amostra foi realizada utilizando-se uma lâmpada de xenônio de $150 \mathrm{~W}$, acoplada a $90^{\circ}$ em relação ao feixe de leitura do monocromador. Para remoção da fração de luz ultravioleta e infravermelha da fonte luminosa, foi utilizado um recipiente de acrilico com $10 \mathrm{~cm}$ de caminho óptico contendo água.

\subsection{MEDIDAS DE LUMINESCÊNCIA}

Os espectros de luminescência foram obtidos utilizando-se um espectrofotômetro LS-100 da Photon Technology Inc. As soluções das amostras nos solventes adequados contidos numa cubeta de quartzo de 4 faces, de caminho óptico igual a $1,0 \mathrm{~cm}$, foram utilizadas nas medidas a temperatura ambiente. Nas medidas a baixa temperatura, utilizou-se um Dewar com dedo frio transparente de quartzo, dentro do qual introduziu-se nitrogênio 
líquido e um tubo de quartzo, de diâmetro de aproximadamente igual a $3 \mathrm{~mm}$, contendo a solução da amostra a ser estudada. As concentrações foram escolhidas de modo a se obter uma absorbância de aproximadamente 0,4 u.a.. O solvente utilizado para preparar as soluções foi etanol absoluto, que permite a obtenção de um vidro rígido transparente quando esfriado em nitrogênio liquido.

O rendimento quântico de fluorescência $\left(\phi_{f \mathfrak{l}}\right)$ foi determinado comparando-se a área sob a banda de fluorescência da amostra com a de um padrão (TPP - tetrafenilporfirina), nas mesmas condições experimentais. É imprescindivel que as populações iniciais no estado excitado singlete $\left(\mathrm{S}_{1}\right)$ sejam iguais. Por isso, as intensidades de absorção no comprimento de onda de excitação $(515 \mathrm{~nm})$ das amostras foram ajustadas para serem os mais próximos possiveis do padrão utilizado. $O \phi_{\text {fl }}$ pode ser calculado segundo a equação 1 , onde $\phi_{\text {fl }}^{P}(0,15), A^{P}$ e $A$ são o rendimento quântico de fluorescência e as áreas sob as bandas de emissão da TPP (meso-tetra-fenilporfirina) e da amostra. Os parâmetros $a^{p} s^{P}$ e abs são as absorbâncias do padrão e da amostra no comprimento de onda de excitação.

eq. $1 \quad \phi_{f l}=\phi_{f l}^{P} \cdot \frac{A}{A^{P}} \cdot \frac{a b s^{P}}{a b s}$

\subsection{FOTÓLISE RELÂMPAGO}

Os experimentos de fotólise relâmpago foram utilizados para determinar o tempo de vida $\left(\tau^{\top}\right)$ e o espectro diferencial da espécie no estado excitado triplete $\left(T_{1}\right)$.

O equipamento consiste de um espectrômetro de absorção/emissão com resolução temporal da Edinburgh Analytical Instruments, modelo LP900S1, que possui um laser pulsado de excitação (266, 355 ou 532 nm) 
Continuum Surelite $\|-10$ (largura de pulso $\pm 5 \mathrm{~ns}$ ) a $90^{\circ}$ do feixe de análise. 0 analisador é constituido por uma lâmpada pulsada de xenônio de $500 \mathrm{~W}$, em linha com um monocromador Czern-Turner $(250$ a $900 \mathrm{~nm}$, resolução máxima $=0,05 \mathrm{~nm})$ e uma fotomultiplicadora Hamamatsu R955(185 a $900 \mathrm{~nm}$ ). O sinal do transiente foi armazenado num osciloscópio digital Tektronix TDS 520 e transferido para um microcomputador IBMIPC através de uma interface IEEE-488.

A lâmpada de xenônio se encontra em linha com o monocromador e a fotomultiplicadora, que faz a leitura contínua da absorção da amostra em um dado comprimento de onda, como num espectrofotômetro convencional. Após alguns milisegundos a amostra é irradiada com um pulso do laser de comprimento de onda de $532 \mathrm{~nm}$, que promove uma fração das moléculas do estado fundamental ao estado excitado. Os resultados são apresentados na forma diferencial para aumentar a sensibilidade do método, ou seja, são apresentadas as curvas correspondentes às diferenças de absorbância após e antes do pulso laser em função do tempo $t>0$. Assim, se as moléculas no estado excitado possuirem um tempo de vida superior a $5 \mathrm{~ns}$, se não existirem processos químicos acoplados e se a absortividade molar do estado excitado for diferente do fundamental, a curva $\triangle \mathrm{Abs}$ vs tempo corresponderá ao de um processo unimolecular simples e poderá ser ajustada por uma exponencial de primeira ordem crescente $(\Delta A b s>0)$ ou decrescente $(\Delta A b s<0)$, segundo a equação:

$$
\text { eq. } 2 y=y_{0}+A \cdot e^{-k x}
$$

onde, $\mathrm{k}$ é a constante de velocidade de decaimento do estado excitado e o recíproco de $\mathrm{k}$ fornece $o$ tempo de vida das moléculas nesse estado. No caso das porfirinas, a velocidade de cruzamento interssistema é relativamente rápida, permitindo medir os parâmetros relativos ao estado triplete $T_{1}$.

O espectro diferencial do estado excitado pode ser obtido plotando-se as intensidades do sinal transiente num tempo $t>0$ em função do comprimento de onda monitorado. $\mathrm{O}$ procedimento fornece um espectro que possui bandas positivas e negativas, pois a absortividade molar da espécie no 
estado excitado pode ser maior ou menor, respectivamente, que no estado fundamental. Assim, as regiões negativas correspondem às regiões com contribuição predominante do estado fundamental e podem ser utilizadas para estimar a fração de moléculas que foram excitadas. Assim, é possivel obter-se o espectro da espécie no estado $T_{1}$ somando-se o espectro do estado fundamental correspondente àquela fração ao espectro diferencial. Todavia, determinar precisamente a contribuição dos espectros de cada um dos dois constituintes não é um processo simples, de modo que é prática comum a apresentação do espectro diferencial ao invés do espectro da espécie $T_{1}$.

Alguns fatores podem interferir nos resultados de tempo de vida, como por exemplo, a concentração de oxigênio ou outros supressores presentes no solvente ou na amostra. $\mathrm{O} \mathrm{O}_{2}$ é um potente supressor do estado triplete, mas pode ser removido pela troca com gás $\mathrm{N}_{2}$ ou Ar através de borbulhamento dos mesmos por aproximadamente 20 minutos. Processos mais criteriosos de desoxigenação como o processo "freeze-pump-thaw" de degaseificação de líquidos deve ser empregado no caso de sistemas mais sensíveis à presença daquele supressor. A absorção de umidade pelo solvente durante 0 experimento é outro fator que pode prejudicar os resultados. Neste caso, a presença de água em solventes apolares pode promover a ocorrência do fenômeno de solvatação preferencial mudando o ambiente químico ao redor das moléculas, ou eventualmente precipitação e turvação da solução.

A fotodecomposição é um outro processo que pode ocorrer quando as espécies no estado excitado são muito reativas, reagindo intra- ou intermolecularmente inclusive com o solvente. Nesse caso, o processo pode ser identificado pelo comportamento da curva de decaimento que não tende a zero ou medindo-se o espectro UV-vis da amostra antes e depois do experimento. 


\subsection{RENDIMENTO QUÂNTICO DE OXIGÊNIO SINGLETE $\left(\phi_{\nu}\right)$}

A determinação do $\phi_{\Delta}$ foi realizada por duas técnicas diferentes. A primeira, denominada de LIRT (Luminescência no Infravermelho Resolvida no Tempo), utiliza um arranjo semelhante ao da técnica de fotólise relâmpago $[51,72,73]$, porém a detecção do sinal é realizada com uma fotomultiplicadora com detector de germânio. Este é sensivel na região do infravermelho próximo possibilitando a determinação da fosforescência do ${ }^{1} \mathrm{O}_{2}$ em $1270 \mathrm{~nm}$. Além disso, o equipamento faz uso de um filtro que absorve os fótons de comprimentos de onda inferiores a $1270 \mathrm{~nm}$ (máximo da banda de fosforescência do oxigênio singlete) para evitar a interferência da luz espalhada. $O$ rendimento quântico de formação de oxigênio singlete $\phi_{\Delta}$ é determinado comparando-se o coeficiente angular do gráfico intensidade da fosforescência versus energia do laser incidente $(\mathrm{mJ})$ das amostras com o de um padrão conhecido, no caso o azul de metileno (AM) em acetonitrila ou $4 \mathrm{P}_{4} \mathrm{Me}$ em $\mathrm{D}_{2} \mathrm{O}$. Esse valor expressa a eficiência de transferência de energia daqueles sensibilizadores para o $\mathrm{O}_{2}$ formando ${ }^{1} \mathrm{O}_{2}\left({ }^{1} \Delta_{g}\right)$ numa dada condição e arranjo experimental, servindo como uma calibração do sistema empregado. Para a comparação da intensidade do sinal da amostra com a do padrão é necessário que suas absorbâncias no comprimento de onda de excitação (no caso $532 \mathrm{~nm}$ ) sejam equivalentes, a fim de garantir que o número de moléculas excitadas sejam iguais. Deve-se também encontrar a faixa de concentração onde o gráfico mantém sua linearidade.

A relação utilizada para os cálculos de $\phi_{\Delta}$ é dada pela equação 3 , onde abs e $a^{p}{ }^{P}$ são as absorbâncias da amostra e do padrão no comprimento de onda de excitação. $\phi_{\Delta}{ }^{P}$ é o rendimento quântico de formação de oxigênio singlete do padrão e $\alpha$ e $\alpha^{P}$ são os coeficientes angulares do gráfico fosforescência versus energia do laser.

$$
\text { eq. } 3 \phi_{\Delta}=\phi_{\Delta}{ }^{P} \cdot \frac{\alpha}{\alpha^{P}} \cdot \frac{a_{b s}^{P}}{a b s}
$$

A segunda técnica $[51,74]$ utilizada neste sentido, consiste na medida indireta da formação do ${ }^{1} \mathrm{O}_{2}$, realizada através da reação desta espécie com 
4.6 - Rendimento Quântico de Oxigênio Singlete ( $\left.\phi_{\Delta}\right)$

um supressor químico, por exemplo o RB (rubreno) ou DFBF (1,3-difenilisobenzofurano), cujas estruturas são mostradas na figura 12. O DFBF apresenta uma banda bastante intensa em $411 \mathrm{~nm}\left(2,2 \times 10^{4} \mathrm{M}^{-1} \cdot \mathrm{cm}^{-1}\right.$, em etanol ou metanol), porém o fotoproduto da sua rápida reação com $0{ }^{1} \mathrm{O}_{2}$ formado não apresenta bandas de absorção na região de 190 a 1100 nm. Assim, $\quad 0 \quad{ }^{1} \mathrm{O}_{2}$ gerado fotoquimicamente pode ser monitorado espectrofotometricamente pela variação da absorbância em $411 \mathrm{~nm}$. Deve-se evitar a excitação em comprimentos de onda em que o supressor também absorva, pois frequentemente apresentam elevada eficiência de formação de ${ }^{1} \mathrm{O}_{2}$. A velocidade de consumo do DFBF é diretamente proporcional ao $\phi_{\Delta}$ do sensibilizador e da potência da fonte luminosa utilizada para irradiar a solução por unidade de tempo, $\mathrm{l}_{\mathrm{a}}$, segundo na equação 4.

\section{RB -Rubreno}<smiles>c1ccc(-c2c3c(-c4ccccc4)c4ccccc4c-3c(-c3ccccc3)c3ccccc3c2-c2ccccc2)cc1</smiles>

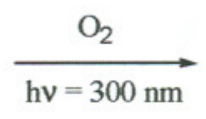

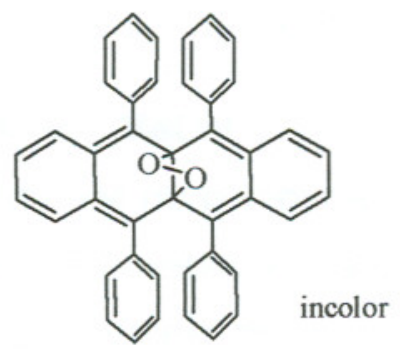<smiles>c1ccc(-c2oc(-c3ccccc3)c3ccccc23)cc1</smiles>

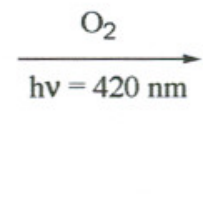

DFBF - 1,3 difenil isobenzofurano

Figura 12: Estruturas dos supressores rubreno e 1,3-difenil isobenzofurano e respectivos produtos de reação $\operatorname{com}^{1} \mathrm{O}_{2}$.

$$
\text { eq. } 4-\frac{d[D F B F]}{d t}=-\frac{d A}{d t} \frac{L}{\varepsilon_{D P B F} L}=l_{a} \phi_{\Delta} \frac{k_{r}[D F B F]}{k_{r}[D F B F]+k_{d}}
$$


4.6 - Rendimento Quântico de Oxigênio Singlete $\left(\phi_{\Delta}\right)$

onde, $k_{r}$ e $k_{d}$ são as constantes de velocidade de desativação bimolecular (do ${ }^{1} \mathrm{O}_{2}$ com o DFBF) e unimolecular do ${ }^{1} \mathrm{O}_{2}$, respectivamente. $\varepsilon_{\text {DFBF }}$ e A são a absortividade molar e a absorção do DFBF em $411 \mathrm{~nm}$ e L é o caminho óptico $(1,0 \mathrm{~cm})$. Plotando-se o inverso da derivada do gráfico $A$ vs tempo em função do inverso de $A$ obtém-se uma reta cujo coeficiente linear é proporcional a $1 / \phi_{\Delta}$, segundo a equação 5 .

$$
\text { eq. } 5-\left[\frac{d A}{d t}\right]^{-1}=\frac{1}{l_{a} \phi_{\Delta} \varepsilon_{D F B F} L}+\frac{k_{d}}{k_{r} l_{a} \phi_{\Delta}} \frac{1}{A}
$$

Todavia, neste caso, é necessário saber o valor de $\mathrm{l}_{\mathrm{a}}$. Este pode ser determinado utilizando-se uma solução de uma substância padrão (com $\phi_{\Delta}$ conhecido), com a mesma absorbância no comprimento de onda de irradiação. Nestes experimentos foi utilizado como padrão o azul de metileno (AM; $\left.\lambda_{\text {exc }}=600 \mathrm{~nm} ; \quad \phi_{\Delta}=0,50 ; \quad \mathrm{l}_{\mathrm{a}}=6,0 \times 10^{-7} \mathrm{M} \cdot \mathrm{s}^{-1}\right)$ e cloreto de tris $\left(2,2^{\prime}-\right.$ bipiridina)rutênio(II) ([Ru(bipy) $\left.)_{3}\right] \mathrm{Cl}_{2} ; \lambda_{\text {exc }}=480 \mathrm{~nm} ; \phi_{\Delta}=0,80 ; \mathrm{I}_{\mathrm{a}}=1,15 \times 10^{-7} \mathrm{M} \cdot \mathrm{s}^{-1}$ ).

Quando os experimentos foram realizados em $\mathrm{MeOH}$ ou $\mathrm{EtOH}$ foi observada uma diminuição na banda de absorção do AM no comprimento de onda de irradiação. Nestes solventes próticos o AM apresenta tendência de sofrer redução à medida que a concentração de $\mathrm{O}_{2}$ do meio diminui. Desta forma os ensaios foram conduzidos em MeCN para evitar esse inconveniente.

O método é bastante eficiente, porém, em virtude do gráfico ser uma função do recíproco da concentração, ele é dominado pelos dados à baixas concentrações de sensibilizador. Isso frequentemente leva a erros elevados e a falta de reprodutibilidade, pois o coeficiente linear toma-se muito mais sensiveis às condições experimentais. Outra forma bastante eficiente de se calcular os coeficientes angulares e lineares é integrar a equação 5, e plotar o gráfico tempo $\times \mathrm{A}$, segundo a equação 6 . O ajuste de curvas dos dados experimentais com a equação 6 pode ser realizado facilmente utilizando o 
4.7 - Coeficiente de Partição n-Octanol/Água ( $\left.\log P_{O A}\right)$ ou n-Butanol/Água $\left(\log P_{B A}\right)$

programa Origin $®$ (Microcalc), por exemplo. Aparentemente o desvio padrão utilizando esta estratégia é menor que o método descrito anteriormente.

$$
\text { eq. } 6 \quad t=\frac{\left(A-A_{o}\right)}{l_{a} \phi_{\Delta} \varepsilon_{D P B F} L}+\frac{k_{d}}{k_{r} l_{a} \phi_{\Delta}} \cdot \ln \left(\frac{A}{A_{o}}\right)
$$

\subsection{COEFICIENTE DE PARTIÇÃO N-OCTANOLÁ́GUA (logPOA)}

O coeficiente de partição $(\log P)$ é um parâmetro físico-químico que pode ser utilizado para estimar a afinidade relativa de uma dada espécie por uma fase lipofilica, como a membrana celular, e uma fase aquosa. Geralmente uma mistura bifásica $n$-octanol/água ou $n$-octanol/tampão é utilizada para mimetizar a interfase membrana/água. Assim, dependendo do equilíbrio de partição de um dado composto nesse sistema bifásico, pode-se inferir a tendência do mesmo de interagir e/ou de se incorporar nas membranas biológicas (lipofilicidade; $\quad \log P>0$ ) ou permanecer na fase aquosa (hidrofilicidade; $\log \mathrm{P}<0$ ).

Para a determinação do logP foi utilizado o método convencional, denominado de "shake flask", por ser simples, válido numa ampla faixa de valores tanto positivos como negativos $\left(-4<\log \mathrm{P}_{O A}<4\right)$, e pelo fato de poder ser realizado com equipamentos comuns do laboratório, como um espectrofotômetro e uma centrifuga. Os experimentos foram realizados em água desionizada ao invés de solução tamponada, pois o aumento da forçaiônica pode provocar alguns inconvenientes como agregação que poderia influenciar significativamente os resultados. O pKa para protonação do anel porfirínico para todas as espécies estudadas é aproximadamente igual a 2,2, de modo que esse equilibrio não contribui para os resultados obtidos.

Assim, inicialmente uma mistura estoque de $n$-octanol e água foram agitadas de forma vigorosa por 1 hora, a fim de promover o equilíbrio de ambas as fases. Em seguida as fases foram separadas por centrifugação e as amostras misturadas com um volume conhecido de uma das fases. A 
4.7 - Coeficiente de Partição n-Octanol/Água ( $\left(\log P_{O A}\right)$ ou n-Butanol/Água $\left(\log P_{B A}\right)$

concentração inicial foi controlada de modo que a absorção máxima na banda Soret fosse igual a $\sim 1$ u.a.. Não há necessidade dos volumes das fases de $n$ octanol e aquosa serem iguais, de modo que um volume adequado da outra fase foi adicionado e a mistura agitada vigorosamente por 15 minutos para que o sistema atinja o equilibrio de partição. Toda a mistura foi então centrifugada a $6 \times 10^{3}$ rpm por 3 minutos e as concentrações antes e após o equilibrio de partição determinadas espectrofotometricamente, registrando-se os espectros UV-vis. As equações 7 e 8 foram utilizadas quando a amostra foi dissolvida em água e $n$-octanol, respectivamente. Em ambos os casos, $A^{i}$ e $A^{f}$ são as absorbâncias da amostra, antes e depois do equilibrio de fases e $\mathrm{V}_{\mathrm{H} 2 \mathrm{O}} \mathrm{e}$ $\mathrm{V}_{\mathrm{OcOH}}$ são os respectivos volumes.

$$
\begin{gathered}
\text { eq. } 7 \quad \log P=\log \left[\frac{\left(A_{\left.\mathrm{H}_{2} \mathrm{O}-A_{\mathrm{H}_{2} \mathrm{O}}^{f}\right)}^{A_{\mathrm{H}_{2} \mathrm{O}}} \frac{V_{\mathrm{H}_{2} \mathrm{O}}}{V_{\mathrm{OCOH}}}\right]}{\text { eq. } 8 \quad \log P=\log \left[\frac{A_{\mathrm{OCOH}}^{f}}{\left(A_{\mathrm{OCOH}}^{i}-A_{\mathrm{OCOH}}^{f}\right)} \frac{V_{\mathrm{H}_{2} \mathrm{O}}}{V_{\mathrm{OCOH}}}\right]}\right.
\end{gathered}
$$

Note que caso volumes desiguais sejam utilizados, estes precisam ser considerados no cálculo do coeficiente de partição, pois o potencial quimico de uma dada espécie é proporcional à concentração das mesmas. O equilíbrio de partição é atingido quando o potencial químico em ambas as fases se tornam equivalentes. Assim, deve-se tomar cuidado para excluir quaisquer outras espécies que não estejam envolvidas no processo desejado, ou trabalhar em concentrações próximas à saturação de quaisquer umas das fases. Neste caso, é muito comum a formação de precipitados muito finos que passam despercebidas, ou a adsorção do composto nas paredes do recipiente ou pode-se atingir um falso equilibrio de partição, provocando erros nas medidas. Para evitar os problemas citados, é recomendável sempre dissolver a amostra na fase em que ele é menos solúvel. 


\subsection{EFICIÊNCIA DA HEMÓLISE DE ERITRÓCITOS}

Os eritrócitos são células anucleadas responsáveis pelo transporte de oxigênio pelo sangue e se assemelha a uma bolsa contendo hemoglobina. Devido ao seu tamanho $(\sim 7,8 \mu \mathrm{m})$, apresentam a propriedade de espalhar luz visivel. Obviamente, a presença da hemoglobina leva ao aparecimento de bandas de absorção características. Todavia, os estudos realizados visavam a determinação da eficiência de hemólise, ou seja, quão eficientemente a membrana externa dos eritrócitos é rompida pelo oxigênio singlete gerado pela irradiação dos mesmos na presença dos sensibilizadores porfirínicos catiônicos. Assim, os experimentos consistiram em monitorar a variação da intensidade de espalhamento da suspensão de eritrócitos em função do tempo [75,76], na ausência e presença das porfirinas catiônicas, sob irradiação constante. A medida que a membrana externa dos eritrócitos são danificadas pelos ${ }^{1} \mathrm{O}_{2}$ formado, observa-se uma diminuição do espalhamento e $\mathrm{o}$ aparente aumento das bandas de absorção da oxi-hemoglobina em 420 e $585 \mathrm{~nm}$. Estes eventos são consistentes com o rompimento da membrana celular do eritrócito segundo o mecanismo acima descrito.

O sangue utilizado foi extraido de ratos Sprague-Dawley, anestesiados com éter. A caixa torácica foi aberta e $5 \mathrm{~mL}$ de sangue foram aspirados com uma seringa contendo $2 \mathrm{~mL}$ de uma solução de citrato, para evitar a coagulação do sangue. A mistura foi centrifugada a $3000 \mathrm{rpm}$ por 3 minutos a $4^{\circ} \mathrm{C}$. Em seguida, o sobrenadante foi descartado, o material depositado no fundo dos tubos (pellet) foi ressuspendido com $15 \mathrm{~mL}$ de solução salina de tampão fosfato (PBS - Biowhittaker) e a amostra novamente centrifugada. Este procedimento foi repetido mais 3 vezes visando a eliminação de proteinas (principalmente albumina), de fatores de coagulação $\left(\mathrm{Ca}^{2+}\right)$ e de plaquetas e glóbulos brancos. A amostra foi então diluida com tampão PBS até obter-se uma suspensão com espalhamento de 0,7 u.a.

Os experimentos de irradiação foram realizados num arranjo idêntico ao descrito para a irradiação de mitocôndrias isoladas, ou seja, o feixe de 
4.9 - Interação com Mitocôndrias Isoladas e Efeitos da Irradiação

excitação (laser em $532 \mathrm{~nm}$ ) foi posicionado perpendicularmente ao feixe de análise do espectrofotômetro HP8453. Os experimento foram realizados utilizando-se uma cubeta de quartzo de quatro faces polidas e mantendo-se agitação constante com uma barra magnética. $1 \mathrm{~mL}$ de PBS e $\sim 10 \mu \mathrm{L}$ de uma solução etanólica de porfirina $(\sim 5 \mu \mathrm{M})$ foram adicionados, gerando uma solução com absorção de 1,0 u.a. na banda Soret. Desta forma foi assegurado uma população constante da espécie no estado excitado para todas as porfirinas. $O$ espectrofotômetro foi configurado para realizar a aquisição automática de espectros em intervalos de tempos definidos e as medidas foram iniciadas. Então, $4 \mu \mathrm{L}$ daquela suspensão de eritrócitos foi rapidamente adicionada e após um tempo de espera de 100 segundos para o sistema atingir o equilíbrio, foi iniciada a irradiação $(532 \mathrm{~nm}, 20 \mathrm{~mW})$. O espalhamento foi monitorado em $650 \mathrm{~nm}$, onde tanto a porfirina quanto a oxi-hemoglobina não apresentam bandas de absorção ou absorvem muito fracamente.

\subsection{INTERAÇÃO COM MITOCÔNDRIAS ISOLADAS E EFEITOS DA IRRADIAÇÃO}

Foram sugeridos em inúmeros artigos publicados em revistas científicas especializadas $[26,29]$ que substâncias (drogas) catiônicas acumulam-se preferencialmente em mitocôndrias em relação a outras organelas, devido à atração eletrostática devido ao seu potencial de membrana $(\Delta \psi)$. Com a intenção de investigar esse aspecto, ou seja, se o potencial de membrana mitocondrial realmente favorece a interação com as porfirinas catiônicas, foram realizados experimentos de ligação das mesmas em condições onde as mitocôndrias se encontravam energizadas (máximo $\Delta \psi$ ) e desacopladas $(\Delta \psi \sim 0)$.

O método utilizado para a determinação da afinidade da ligação porfirinas/mitocôndria consistiu na titulação de uma solução de porfirina com volumes crescentes de uma suspensão de mitocôndria. As amostras foram centrifugadas e as concentrações de porfirina no sobrenadante e no 
4.9 - Interação com Mitocôndrias Isoladas e Efeitos da Irradiação

precipitado foram determinadas espectrofotometricamente na região do UVVis.

Foi desenvolvido um protocolo para a determinação da quantidade de porfirina ligada à mitocôndria, utilizando uma solução aquosa de $\mathrm{HCl}(22 \%)$. $\mathrm{A}$ estratégia consiste em protonar o anel porfirínico tornando a espécie mais hidrofílica e promovendo sua liberação para o seio da solução. A acidificação do meio também intensifica a coloração da solução e diminui a tendência daqueles compostos de adsorverem nas paredes dos recipientes e na cubeta, pois tornam-se muito mais hidrofilicas. Isso minimiza os erros cumulativos na leitura da absorção das amostras, tornando os experimentos mais rápidos e confiáveis.

Para manter a suspensão mitocondrial energizada, os experimentos foram realizados na presença de oligomicina e rotenona. A primeira é uma droga inibidora do ATP sintase, e impede o transporte de prótons para o interior da organela. A segunda, bloqueia o complexo I da cadeia respiratória evitando a transferência de prótons do meio interno para o externo. Como consequência a suspensão de mitocôndrias permanece com o potencial de membrana semelhante ao encontrado em condições celulares.

O desacoplamento da membrana pode ser obtido utilizando-se um ionóforo que permite a saída dos prótons, o CCCP (carbonilciano $p$ triclorometoxifenilidrazina). Este protonóforo é um ácido orgânico fraco de caráter lipofílico, que pode permear através da bicamada lipídica tanto na sua forma protonada como desprotonada. Como conseqüência, o CCCP atua como transportador transmembrânico de $\mathrm{H}^{+}$, tornando sua concentração no interior equivalente ao do meio externo, dissipando o gradiente de concentração de prótons, mesmo na presença de oligomicina.

Todos os experimentos envolvendo mitocôndrias isoladas foram realizados em solução tampão $(\mathrm{pH} 7,2)$ contendo $1 \mathrm{mM}$ de hidrogenofosfato de potássio, $250 \mathrm{mM}$ de sacarose, $10 \mathrm{mM}$ de Hepes, $2 \mathrm{mM}$ de succinato e $1 \mathrm{mM}$ de EGTA. 
4.9 - Interação com Mitocôndrias Isoladas e Efeitos da Irradiação

A suspensão de mitocôndrias foi isolada a partir de figado de rato adulto (Sprague-Dawley) utilizando-se o método de centrifugação diferencial [30]. O fígado do rato foi removido, picotado em tampão e homogeneizado com potter. A suspensão foi então centrifugada a $4^{\circ} \mathrm{C}$ a $2 \times 10^{3} \mathrm{rpm}$ por 5 minutos para remover o material não homogeneizado e núcleos. O sobrenadante foi separado e novamente centrifugado a $1 \times 10^{4} \mathrm{rpm}$ por 10 minutos para promover a sedimentação das mitocôndrias. Em seguida, o sobrenadante foi descartado e o pellet ressuspendido e centrifugado. Todo o procedimento foi realizado em banho de gelo, para evitar a degradação da amostra. A concentração da suspensão enriquecida de mitocôndrias foi estimada dosando a concentração de proteinas pelo método do biureto [77]. A concentração foi ajustada para aproximadamente $12 \mathrm{mg} / \mathrm{mL}$ por meio da adição de tampão.

Em seguida, foram adicionados volumes variados da suspensão de mitocôndrias em eppendorfs contendo $0,5 \mu \mathrm{L}$ de rotenona ( $1 \mu \mathrm{M}$ - Aldrich), oligomicina ( $1 \mu \mathrm{M}$ - Aldrich) e $1 \mathrm{~mL}$ de uma solução $\sim 6 \mu \mathrm{M}$ das porfirinas, preparadas no mesmo tampão citado acima. Finalmente, o volume de tampão necessário para se completar o volume total de $1,1 \mathrm{~mL}$ foi adicionado. Imediatamente após a adição da suspensão de mitocôndrias (menos de 3 minutos), as amostras foram centrifugadas por 2 minutos a $15 \times 10^{3} \mathrm{rpm}$, à temperatura ambiente. Um volume definido do sobrenadante $(0,7 \mathrm{~mL})$ foi coletado e adicionado a $50 \mu \mathrm{L}$ de uma solução de $\mathrm{HCl} 22 \%(\mathrm{v} / \mathrm{v})$, e a absorbância medida em $438 \mathrm{~nm}$ (banda Soret) numa cubeta de $0,4 \mathrm{~cm}$ de caminho óptico. A solução restante no eppendorf foi descartada e ao sólido foi adicionado $0,7 \mathrm{~mL}$ da solução de $\mathrm{HCl}$, a fim de remover a porfirina incorporada na mitocôndria. Este procedimento também permite verificar se houve processo redox com a porfirina incorporada.

Em seguida, a suspensão foi novamente centrifugada e a absorbância do sobrenadante medida em $448 \mathrm{~nm}$ (banda Soret). $O$ deslocamento da banda Soret de 438 para $448 \mathrm{~nm}$, provavelmente se deve à interação das porfirinas protonadas com algum fragmento de mitocôndria desnaturada. Todavia, para efeito de cálculos foram consideradas como tendo as mesmas absortividades molares. Assim, após as correções decorrentes das diversas diluições, foi 
4.9 - Interação com Mitocôndrias Isoladas e Efeitos da Irradiação

possivel determinar a concentração de porfirina ligada na mitocôndria e a presente em equilibrio no sobrenadante.

As mitocôndrias são organelas complexas apresentando um potencial de membrana negativo e vários sítios de ligação para as porfirinas [26]. Além disso, o número médio de sítios de ligação por mitocôndria não é conhecido, tornando impossivel a determinação de uma constante de equilíbrio de incorporação convencional. Porém, a constante de ligação porfirinamitocôndria $\left(K_{L}{ }^{M}\right)$ pode ser calculada com base na concentração em massa da mitocôndria e considerando-se que os sítios de interação são independentes e que a afinidade é relativamente baixa, de modo que sempre exista um excesso de mitocôndrias e porfirina livres no equilibrio. Nesse caso, $\mathrm{K}_{\mathrm{L}}{ }^{\mathrm{M}}$ pode ser estimado empregando-se a equação 9 , onde $[P]$ é a concentração de porfirina livre, presente no sobrenadante, [M] a concentração de mitocôndria não ligada e [P-M] a concentração de porfirina ligada à mitocôndria.

eq. 9

$$
\begin{gathered}
{[P]+[M] \stackrel{K_{L}{ }^{M}}{\rightleftharpoons}[P-M]} \\
K_{L}{ }^{M}=\frac{[P-M]}{[P][M]}
\end{gathered}
$$

Os experimentos com a mitocôndria desacoplada foram realizados utilizando um procedimento semelhante ao descrito acima. Porém, neste caso, as concentrações do fotossensibilizador $(\sim 10 \mu \mathrm{M})$ e de mitocôndria $(0,85$ ou $1,70 \mathrm{mg} \cdot \mathrm{mL}^{-1}$ ) foram mantidas constantes, e os experimentos foram conduzidos na presença ou na ausência de CCCP.

A irradiação da suspensão mitocondrial e das porfirinas catiônicas foi realizada numa cubeta de quartzo (quatro faces polidas e caminho óptico igual a 1,0 cm) contendo $1 \mathrm{~mL}$ de solução tampão com $\sim 4 \mu \mathrm{M}$ de porfirina( 1 u.a. na banda Soret) e 0,15 mg. $\mathrm{mL}^{-1}$ de suspensão de mitocôndria. $A$ irradiação em 
$532 \mathrm{~nm}(20 \mathrm{~mW})$ foi realizada imediatamente após a adição da mitocôndria, sob agitação lenta com uma barra magnética, para evitar danos mecânicos à organela, sendo os espectros eletrônicos coletados em função do tempo de irradiação.

\subsection{INTERAÇÃO COM LIPOSSOMOS}

O estudo com lipossomos foi utilizado principalmente como sistema modelo para avaliar o grau de interação dos fotossensibilizadores com as biomoléculas e para investigar a existência de sítios de reconhecimento na membrana mitocondrial ou de células tumorais. Neste caso, se o perfil de ligação com lipossomos for semelhante ao daqueles com mitocôndrias e células, então pode-se concluir que a interação não ocorre via sitio de reconhecimento específico. A suspensão foi propositalmente preparada de forma a isolar a fração lipossomal mais pesada, passiveis de serem centrifugadas como no caso das mitocôndrias.

Além disso, com a intenção de mimetizar a composição de lipídios da membrana mitocondrial, foram adicionados uma mistura de dois fosfolipídios diesteroilfosfocolina e cardiolipina na proporção de $80 \% / 20 \%$. Assim, duas soluções etanólicas contendo $6,3 \mathrm{mg}(8 \mu \mathrm{mols})$ de 1,2-diesteroil-sn-glicero-3fosfocolina (DSPC) e $3,0 \mathrm{mg}$ ( $2 \mu \mathrm{mols}$ ) de cardiolipina (CL), ambas da Avanti, foram sêcas com fluxo de argônio para formar um filme no recipiente. Então $2 \mathrm{~mL}$ de solução tampão de TRIS/HCl $5 \mathrm{mM} \mathrm{pH} \mathrm{7,2} \mathrm{foram} \mathrm{adicionadas} \mathrm{e}$ vortexadas por 3 minutos. A suspensão foi centrifugada por 3 minutos a $15000 \mathrm{rpm}$, à temperatura ambiente, e o sobrenadante contendo lipossomos mais leves foi descartado. O pellet foi ressuspendido no mesmo volume de tampão, homogeneizado e novamente centrifugado. $\mathrm{O}$ mesmo procedimento foi realizado mais duas vezes e a concentração de lipossomos final foi estimada através da dosagem de fosfato pelo método do molibdato [78]. 
O experimento para determinar a constante de ligação porfirinalipossomo $\left(\mathrm{K}_{\mathrm{L}}{ }^{\mathrm{L}}\right)$ foi realizado utilizando método análogo ao empregado no caso das suspensões de mitocôndria isolada.

\subsection{INTERAÇÃO COM FIBROBLASTOS CANCEROSOS - HELA}

Para os estudos de interação das porfirinas com células tumorais, foram utilizados fibroblastos cancerosos de origem humana, chamados células HeLa.

As células cancerígenas foram crescidas em garrafas de cultura utilizando meio de cultura DMEM (Cultilab) acrescido de 10\% de soro fetal bovino (Cultilab) e 1\% de antibiótico penicilina e estreptomicina (Biowhittaker). A incubação foi realizada em estufa à $37^{\circ} \mathrm{C}$, em ambiente úmido e na presença de $5 \%$ de gás carbônico, por periodos de 24 horas. Por se tratarem de uma linhagem de células que se aderem às paredes do recipiente, o meio de cultura pode ser trocado sem a necessidade de centrifugação da amostra. O meio de cultura foi trocado periodicamente até as células cobrirem toda a superfície de uma das faces da garrafa. Então o meio de cultura foi removido e as células lavadas com aproximadademente $5 \mathrm{~mL}$ de PBS. Para 0 desprendimento das células do fundo do recipiente foram adicionados $5 \mathrm{~mL}$ de tripsina (Biowhittaker) e este volume foi então dividido em placas individuais, as quais foram adicionadas $1 \mathrm{~mL}$ de DMEM e incubadas novamente à $37^{\circ} \mathrm{C}$, por 24 horas.

A determinação da viabilidade celular, ou seja a concentração de células vivas e mortas, foi realizada pelo teste com o corante azul de tripan. As células mortas apresentam membrana rompida o que possibilita a internalização do corante, enquanto que as células vivas permanecem acinzentadas. O teste consiste na remoção de uma aliquota da suspensão celular, seguido da adição de $10 \%$ em volume de solução de azul de tripan a $0,4 \%$ (Biowhittaker). Após um minuto, faz-se a contagem do número de células utilizando um hematocitômetro e um microscópio convencional. A contagem é feita em 
4.11 - Interação com Fibroblastos Cancerosos - HeLa

quatro quadrantes dos campos existentes. Através do número médio de células contadas, obtém-se uma amostragem estatística de toda a cultura celular.

A viabilidade celular daquelas placas foi monitorada diariamente até atingir $10^{6}$ células vivas por mililitro de solução. Em seguida o meio de cultura foi removido $1 \mathrm{~mL}$ de PBS e $100 \mu \mathrm{L}$ de uma solução aquosa $0,7 \mathrm{mM}$ de porfirina foram adicionadas. As placas foram incubadas no escuro, retiradas e monitoradas em função do tempo.

A quantidade de porfirina ligada e não ligada foi determinada por espectrofotometria UV-vis, após coleta de uma alíquota do sobrenadante e adição de $30 \mu \mathrm{L}$ de $\mathrm{HCl} 22 \%$.

O restante da solução da placa foi descartada e as células foram lavadas com $1 \mathrm{~mL}$ de $\mathrm{PBS}$, à $4^{\circ} \mathrm{C}$, para remover a porfirina presente em equilíbrio no meio extracelular, tomando-se o cuidado de não remover a fração ligada. Em seguida, foi adicionada $1 \mathrm{~mL}$ de uma solução aquosa de SDS $50 \mathrm{mM}$ para promover a solubilização da membrana celular e liberar a fração de porfirina incorporada. Após 5 minutos, foram adicionados $60 \mu \mathrm{L}$ de $\mathrm{HCl} 22 \%$ e todo o volume foi centrifugado num eppendorf. As absorbâncias das amostras foram lidas em $437 \mathrm{~nm}$ numa cubeta de caminho óptico de 0,4 cm e convertidas em número de mols. As soluções muito concentradas foram diluidas e as concentrações corrigidas considerando-se os volumes utilizados. 


\section{PORFIRINAS cis DUPLAMENTE N-CONFUSAS}

\subsection{RESULTADOS E DISCUSSÕES}

\subsubsection{ESTUDOS DE LUMINESCÊNCIA}

As porfirinas cis duplamente $\mathrm{N}$-confusas apresentaram espectros eletrônicos bastante ricos, sendo possivel observar bandas em toda a região do visivel (tabela 1 e figura 13). A semelhança no perfil dos espectros para a base livre $\left(\mathrm{H}_{2} \mathrm{~N}_{2} \mathrm{CP}\right)$ e suas derivadas metaladas de cobre $\left(\mathrm{CuHN}_{2} \mathrm{CP}\right)$ e prata $\left(\mathrm{AgHN}_{2} \mathrm{CP}\right)$ é bastante grande. Porém, a intensidade da banda em $\sim 610 \mathrm{~nm}$ é duas vezes maior nas espécies metaladas que para a $\mathrm{H}_{2} \mathrm{~N}_{2} \mathrm{CP}$.

A adição de pequena quantidade de vapor de $\mathrm{HCl}$ ou $\mathrm{NH}_{3}$, alterou significativamente o perfil dos espectros eletrônicos. De fato, as soluções das formas neutras apresentam coloração esverdeada enquanto que as protonadas ou desprotonadas são marrons. As sensibilidades destes compostos à traços de resíduos ácidos e básicos é tão evidente que a simples dissolução em solventes não tratados, como por exemplo $\mathrm{CH}_{2} \mathrm{Cl}_{2}$ ou DMF, é mais que suficiente para promover aquelas alterações espectrais. 


\subsection{1 - Estudo de Luminescência}

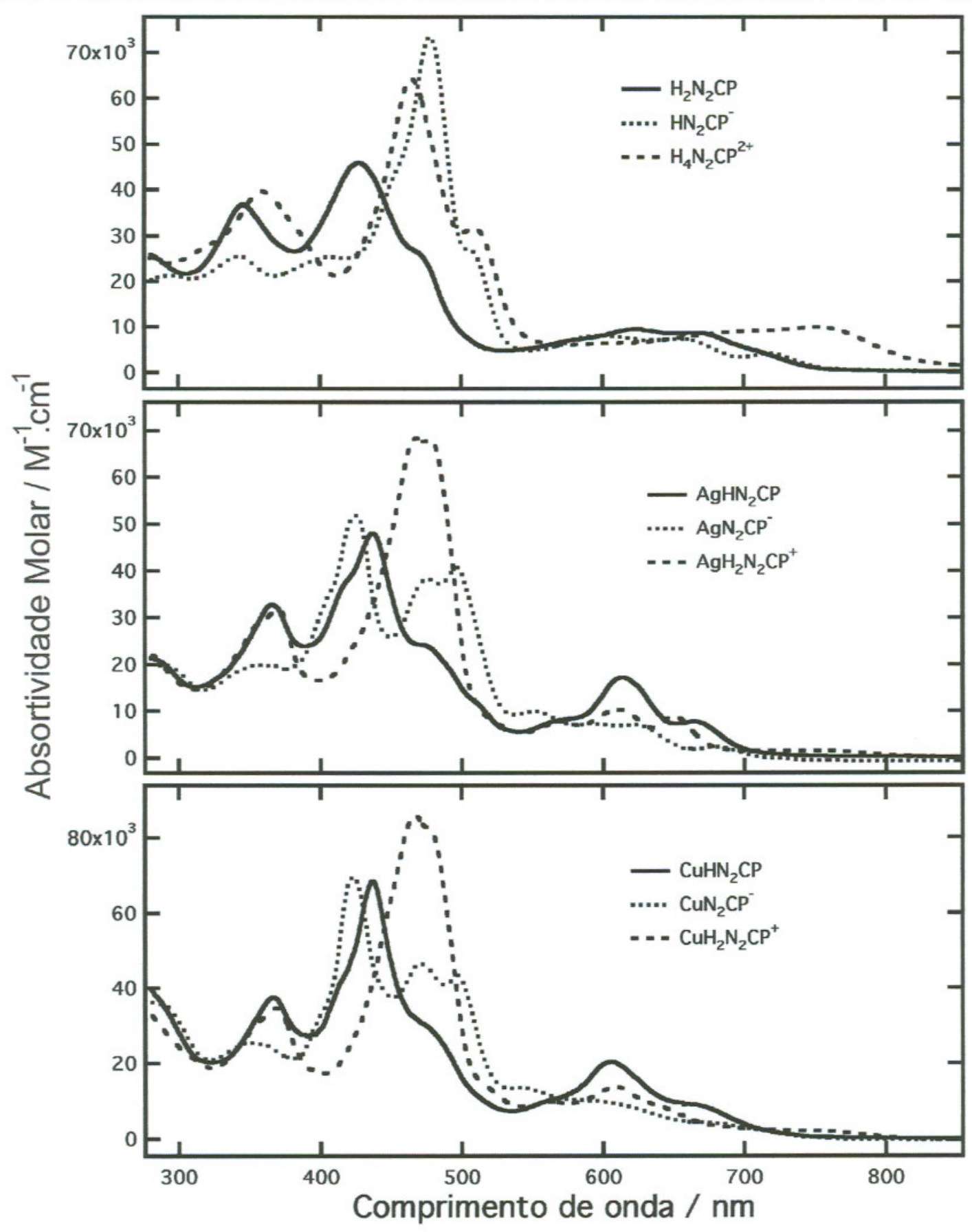

Figura 13: Espectros eletrônicos das porfirinas cis duplamente $\mathrm{N}$-confusas base livre $\left(\mathrm{H}_{2} \mathrm{~N}_{2} \mathrm{CP}\right)$ e dos respectivos complexos de cobre $\left(\mathrm{CuHN}_{2} \mathrm{CP}\right)$ e de prata $\left(\mathrm{AgHN}_{2} \mathrm{CP}\right)$ em solução de acetonitrila, nas suas formas neutras, ácidas e desprotonadas. 
5.1.1 - Estudo de Luminescência

Tabela 1: Tabela mostrando os comprimentos de onda e as absortividades molares (em escala de $\log _{10}$ ) das porfirinas cis duplamente $\mathrm{N}$-confusas em acetonitrila.

\begin{tabular}{c|c|c|c|c|c|c|c|c}
\hline $\mathrm{H}_{2} \mathrm{~N}_{2} \mathrm{CP}$ & $345(4,5)$ & $427(4,7)$ & $472(4,4)$ & $580(3,8)$ & $623(3,9)$ & $668(3,9)$ & $722(3,5)$ & - \\
$\mathrm{H}_{4} \mathrm{~N}_{2} \mathrm{CP}^{2+}$ & $358(4,6)$ & $464(4,8)$ & $510(4,5)$ & $601(3,8)$ & $690(3,9)$ & $750(3,9)$ & - & - \\
$\mathrm{HN}_{2} \mathrm{CP}^{-}$ & $342(4,4)$ & $402(4,4)$ & $450(4,6)$ & $477(4,9)$ & $507(4,4)$ & $600(3,9)$ & $655(3,9)$ & $718(3,6)$ \\
$\mathrm{AgHN}_{2} \mathrm{CP}$ & $364(4,5)$ & $418(4,6)$ & $437(4,7)$ & $475(4,4)$ & $511(4,1)$ & $570(3,9)$ & $613(4,2)$ & $665(3,9)$ \\
$\mathrm{AgH}_{2} \mathrm{~N}_{2} \mathrm{CP}^{+}$ & $370(4,5)$ & $470(4,8)$ & $568(3,9)$ & $610(4,0)$ & $650(3,9)$ & $755(3,2)$ & - & - \\
$\mathrm{AgN}_{2} \mathrm{CP}^{-}$ & $361(4,3)$ & $423(4,7)$ & $473(4,6)$ & $496(4,6)$ & $552(4,0)$ & $625(3,9)$ & $680(3,5)$ & - \\
$\mathrm{CuHN}_{2} \mathrm{CP}$ & $367(4,6)$ & $415(4,6)$ & $437(4,8)$ & $475(4,5)$ & $569(4,0)$ & $606(4,3)$ & $670(3,9)$ & - \\
$\mathrm{CuH}_{2} \mathrm{~N}_{2} \mathrm{CP}^{+}$ & $368(4,5)$ & $466(4,9)$ & $562(3,9)$ & $608(4,1)$ & $644(3,9)$ & $758(3,4)$ & - & - \\
$\mathrm{CuN}_{2} \mathrm{CP}^{-}$ & $353(4,4)$ & $423(4,8)$ & $469(4,7)$ & $495(4,6)$ & $544(4,1)$ & $595(4,0)$ & $683(3,6)$ & - \\
\hline
\end{tabular}

A base livre apresentou uma emissão bastante fraca, mostrando um perfil com duas bandas na região de 700 a $900 \mathrm{~nm}$, características da fluorescência do anel porfirínico (figura 14). O rendimento quântico de fluorescência e 0 formato do espectro de emissão da forma desprotonada $\left(\mathrm{HN}_{2} \mathrm{CP}^{-} ; \phi_{\mathrm{fl}}=6,7 \times 10^{-3}\right)$ e neutra $\left(\phi_{\mathrm{fl}}=9,1 \times 10^{-3}\right)$ são muito semelhantes, tanto em intensidade como em posição. Por outro lado, a forma protonada $\left(\mathrm{H}_{4} \mathrm{~N}_{2} \mathrm{CP}^{2+} ; \phi_{\mathrm{fl}}=0,2 \times 10^{-3}\right)$ apresenta apenas uma única banda deslocada cerca de $90 \mathrm{~nm}$ para regiões de menor energia e com intensidade cerca de 40 vezes menor que das espécies anteriores. O mesmo perfil de emissão foi observado quando a excitação foi realizada em qualquer uma das bandas de absorção do composto. Isto sugere que o estado excitado de menor energia é o estado emissor, provavelmente o singlete $\left(\mathrm{S}_{1}\right)$. Estes resultados são corroborados pelos espectros de excitação, que mostram uma grande similaridade com os espectros de absorção. 


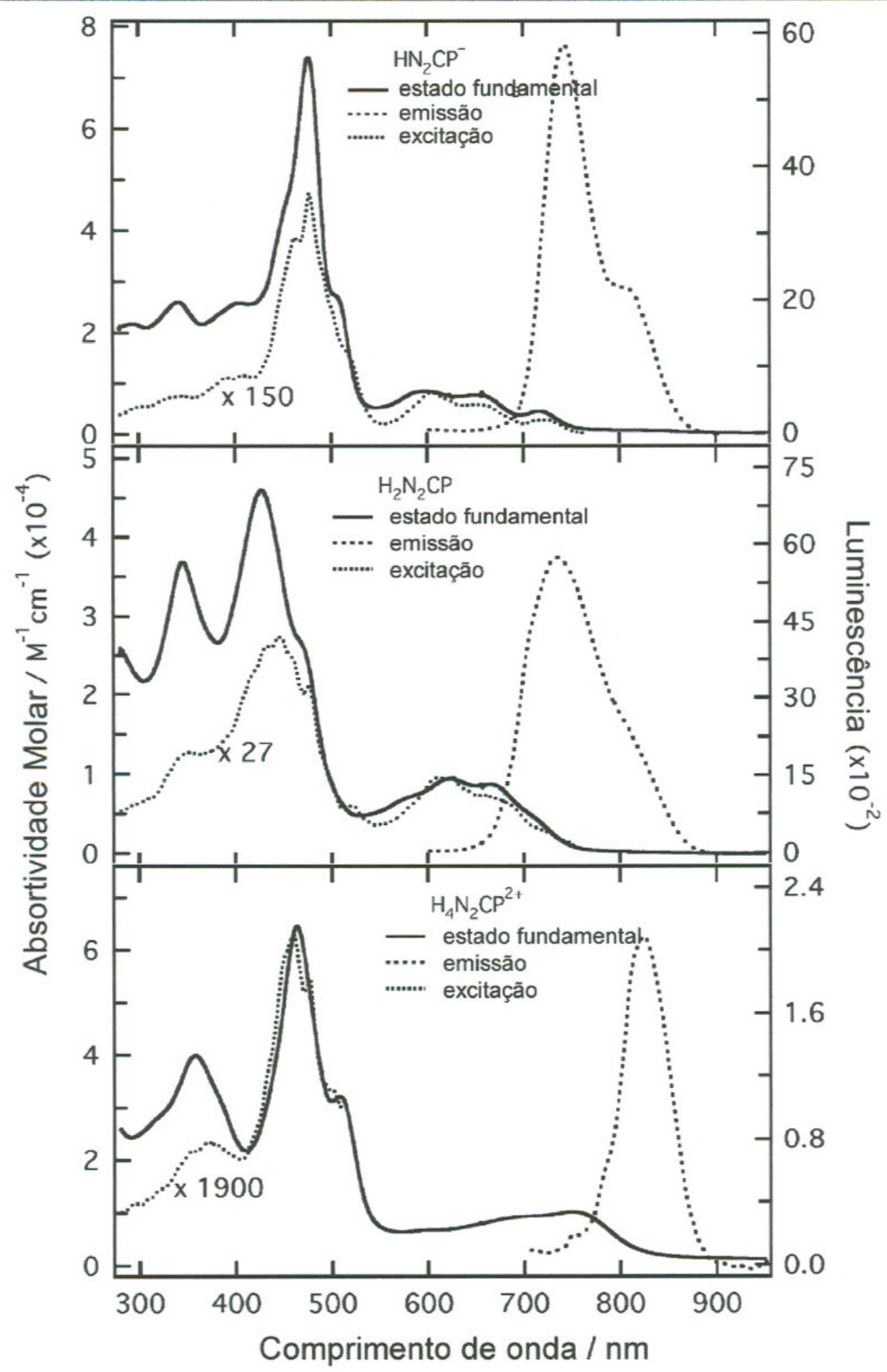

Figura 14: Espectros de emissão (exc. $512 \mathrm{~nm}$ ), excitação e absorção à temperatura ambiente para solução da porfirina duplamente $\mathrm{N}$-confusa base livre nas formas neutra (acima), desprotonada (centro) e protonada (abaixo). 
A introdução de cargas positivas ou negativas na estrutura do composto, provocada pela protonação e desprotonação, parece desativar mais eficientemente o $\mathrm{S}_{1}$ por vias não-radiativas. Neste caso, a maior interação dos grupos carregados com os modos vibracionais do solvente, deve diminuir o tempo de vida da espécie no estado $S_{1}$, diminuindo o $\phi_{\text {fr. }}$ Para a $\mathrm{H}_{4} \mathrm{~N}_{2} \mathrm{CP}^{2+}$, que contém 2 cargas positivas, aquela rota de desativação deve ser ainda mais eficiente.

Os espectros a baixa temperatura (figura 15) não apresentaram bandas relacionadas à fosforescência. Todavia, foi observado uma melhor definição do espectro de fluorescência, além de um deslocamento para o azul de aproximadamente $50 \mathrm{~nm}$ na banda de emissão em vidro de etanol a $77 \mathrm{~K} \mathrm{em}$ relação a solução à temperatura ambiente, como consequuência do efeito da matriz de etanol. 


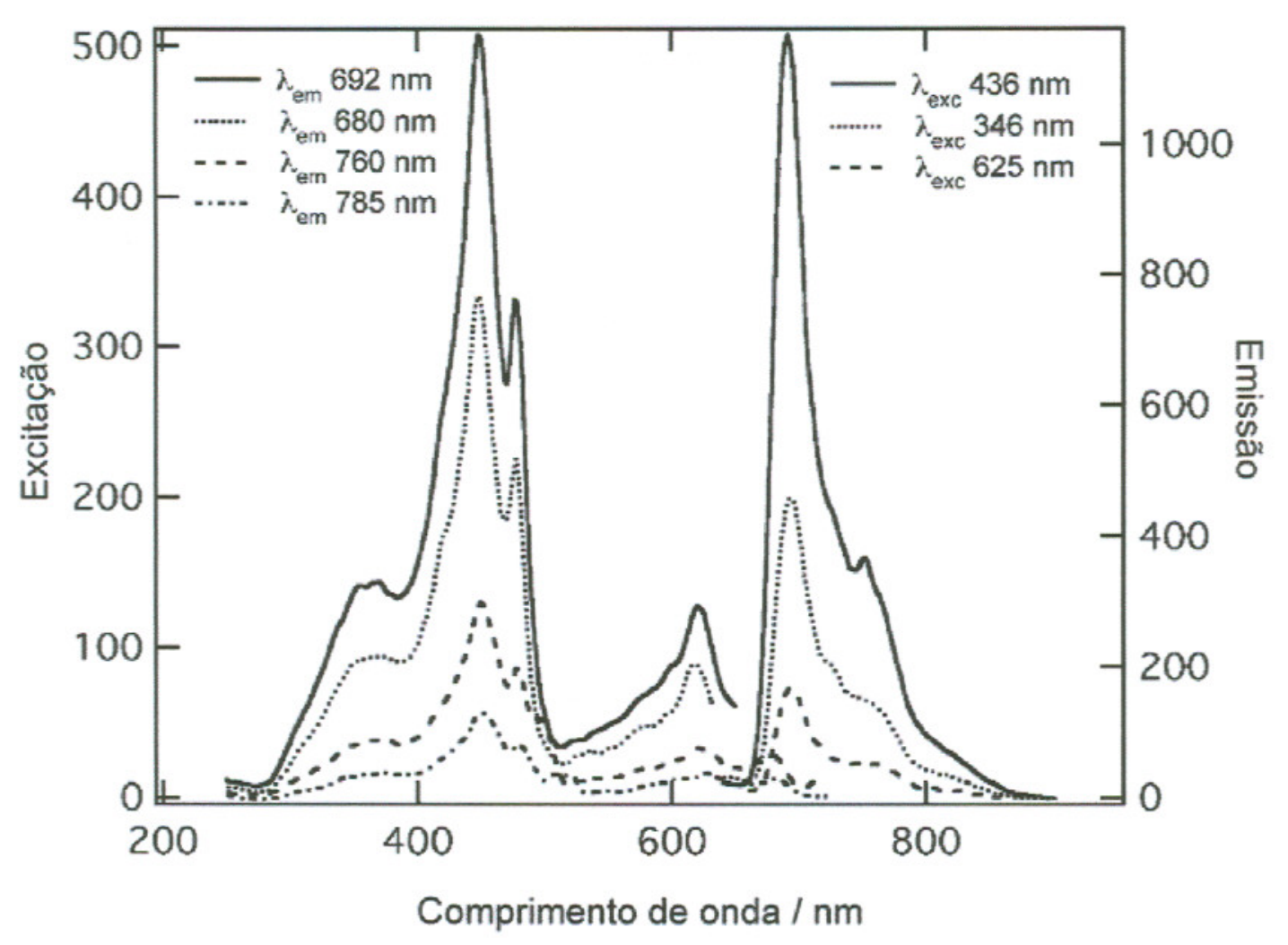

Figura 15: Espectros de excitação (esquerda) e de emissão (direita) da $\mathrm{H}_{2} \mathrm{~N}_{2} \mathrm{CP}$ em vidro de etanol, à $77 \mathrm{~K}$, em diferentes comprimentos de onda de excitação e monitoramento de emissão.

Normalmente, a presença de ions de metais de transição em elevado estado de oxidação suprime a emissão do ligante macrociclico[79], por aumentar a eficiência dos processos não-radiativos em competição aos radiativos. De fato, os experimentos de fluorescência não mostraram nenhuma emissão para a $\mathrm{CuHN}_{2} \mathrm{CP}$ e $\mathrm{AgHN}_{2} \mathrm{CP}$ corroborando a expectativa.

A relaxação não-radiativa está envolvida tanto na dissipação do excesso de energia eletrônica na forma de calor como no aumento da população do estado excitado triplete $\left(T_{1}\right)$ através do cruzamento interssistema (CIS). 
5.1.2 - Estado Excitado Triplete e Rendimento Quântico de ${ }^{1} \mathrm{O}_{2}$

\subsubsection{ESTADO EXCITADO TRIPLETE E RENDIMENTO QUÂNTICO DE ${ }^{1} \mathrm{O}_{2}$}

O espectro diferencial[72] do estado excitado triplete $\left(T_{1} ;\right.$ figura 16) e 0 respectivo tempo de vida $\left(\tau_{0}^{\top}\right.$; tabela 2$)$, obtidos por fotólise relâmpago em solução de acetonitrila desaerada, indicaram que a série de porfirinas duplamente $\mathrm{N}$-confusas apresentam um forte foto-descoramento (photobleaching), particularmente na região de 400 a $500 \mathrm{~nm}$, com tempos de vida variando de 1,1 a $1,8 \mu \mathrm{s}$. De um modo geral, as espécies neutras apresentaram um maior tempo de vida, destacando-se os complexos de $\mathrm{Ag}^{\text {'II }} \mathrm{e}$ $\mathrm{Cu}^{\prime \prime \prime}$ em relação a base livre. Isto sugere que a coordenação destes ions metálicos reduz o número ou a eficiência dos mecanismos de supressão térmica. Logo, provavelmente os 3 hidrogênios internos da base livre estão envolvidos nos mecanismos principais da desativação térmica. 
5.1.2 - Estado Excitado Triplete e Rendimento Quântico de ${ }^{1} \mathrm{O}_{2}$
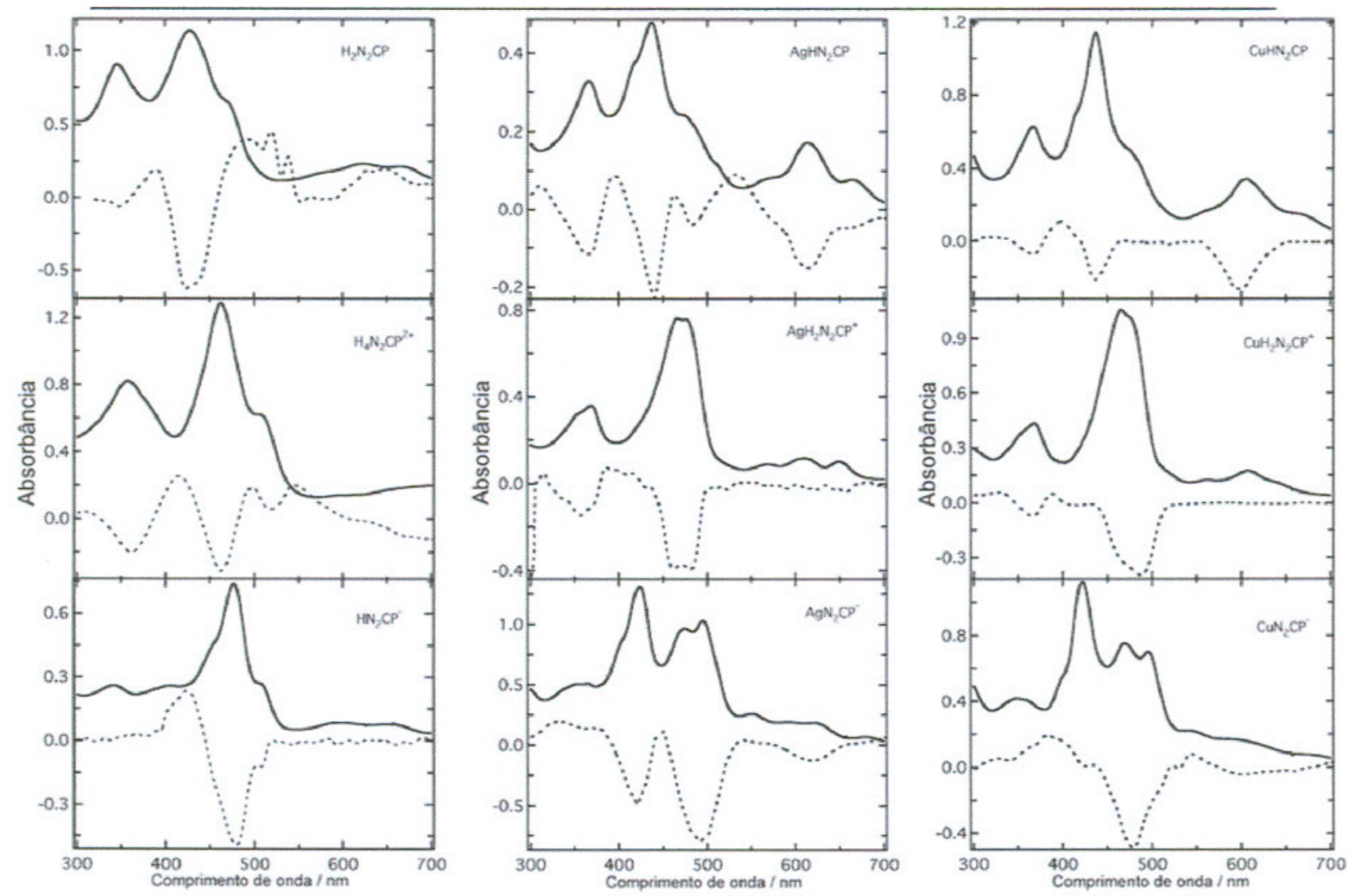

Figura 16: Espectro de absorção (linha sólida) e espectro diferencial do estado excitado triplete $\triangle \mathrm{Abs}$ (linha pontilhada) da base livre (esquerda) e dos complexos de $\mathrm{Ag}^{\prime \prime \prime}$ (centro) e $\mathrm{Cu}^{\prime \prime \prime}$ (direita), em suas formas neutra (acima), protonada (centro) e desprotonada (abaixo).

Os resultados mais interessantes obtidos para as porfirinas duplamente $N$-confusas foram relativos à eficiência na produção de oxigênio singlete $\left(\phi_{\Delta}\right)$ em solução de acetonitrila, determinados pelo método LIRT (Luminescência Infravermelha Resolvida no Tempo)[51] e mostrados na tabela 2. A $\mathrm{H}_{2} \mathrm{~N}_{2} \mathrm{CP}$ nas formas neutra, protonada e desprotonada, apresentaram $\phi_{\Delta}$ relativamente baixos (de 0,1 a 0,2 ), não podendo serem considerados sensibilizadores promissores em terapia fotodinâmica. Por outro lado, as 3 espécies do complexo de $\mathrm{Ag}$ (III) foram mais eficientes que 0 padrão azul de metileno $\left(\phi_{\Delta}=0,50\right)$, com rendimento variando de 0,7 a 0,8 . Estes resultados são similares, por exemplo, ao da benzoporfirina monoácida $\left(\phi_{\Delta}=0,76\right)$ 
5.1.2 - Estado Excitado Triplete e Rendimento Quântico de ${ }^{1} \mathrm{O}_{2}$

recentemente aprovado pelo FDA com o nome comercial de Visudyne®, para tratamento de neovascularização macular [80-82]. Os complexos de Cu' exibiram eficiências intermediárias.

Tabela 2: Tempo de vida do estado triplete $\left(\tau_{0}^{\top}\right)$, constante de supressão bimolecular do ${ }^{1} \mathrm{O}_{2}\left(k_{\text {sup }}\right)$ e rendimento quântico de oxigênio singlete $\left(\phi_{\Delta}\right)$ obtidos por LIRT (Luminescência Infravermelha Resolvida no Tempo) ou DFBF (supressor de ${ }^{1} \mathrm{O}_{2}$ - 1,3-difenilisobenzofurano) para as porfirinas duplamente $\mathrm{N}$-confusas em solução de acetonitrila.

\begin{tabular}{|c|c|c|c|c|c|}
\hline & $\begin{array}{c}\tau_{\circ}^{\top} \\
(\mu s)\end{array}$ & $\begin{array}{c}k_{\text {sup }} \times 10^{-8} / \mathrm{s}^{-1} \\
\text { LIRT }\end{array}$ & $\begin{array}{c}\phi_{\Delta}(532 \mathrm{~nm}) \\
\text { LIRT }\end{array}$ & $\begin{array}{c}\phi_{\Delta}\left(k_{d} / k_{r} \times 10^{5}\right) \\
480 \mathrm{~nm} \text { DFBF }\end{array}$ & $\begin{array}{c}\phi_{\Delta}\left(k_{d} / k_{r} \times 10^{5}\right) \\
600 \mathrm{~nm} \text { DFBF }\end{array}$ \\
\hline $\mathrm{H}_{2} \mathrm{~N}_{2} \mathrm{CP}$ & 1,2 & 9,8 & 0,19 & $0,20(0,98)$ & - \\
\hline $\mathrm{H}_{4} \mathrm{~N}_{2} \mathrm{CP}^{2+}$ & 1,4 & 5,4 & 0,12 & - & - \\
\hline $\mathrm{HN}_{2} \mathrm{CP}^{-}$ & 0,6 & 7,1 & 0,13 & - & - \\
\hline $\mathrm{AgHN}_{2} \mathrm{CP}$ & 1,8 & 1,9 & 0,81 & $0,92(1,08)$ & $0,93(5,1)$ \\
\hline $\mathrm{AgH}_{2} \mathrm{~N}_{2} \mathrm{CP}^{+}$ & 1,1 & 0,42 & 0,67 & - & - \\
\hline $\mathrm{AgN}_{2} \mathrm{CP}^{-}$ & 1,1 & 5,6 & 0,71 & - & - \\
\hline $\mathrm{CuHN}_{2} \mathrm{CP}$ & 1,4 & 11,7 & 0,48 & $0,66(1,14)$ & $0,77(4,9)$ \\
\hline $\mathrm{CuH}_{2} \mathrm{~N}_{2} \mathrm{CP}^{+}$ & 0,1 & 1,9 & 0,22 & - & - \\
\hline $\mathrm{CuN}_{2} \mathrm{CP}^{-}$ & 1,2 & 16,0 & 0,45 & - & - \\
\hline
\end{tabular}

Durante os experimentos de $\phi_{\Delta}$, monitorando a fosforescência do oxigênio singlete em $1270 \mathrm{~nm}$, foi observada uma variação bastante significativa entre as curvas de decaimento radiativo (fosforescência em $1270 \mathrm{~nm}$ ) do ${ }^{1} \mathrm{O}_{2}$ para as porfirinas e para o padrão $\mathrm{AM}$ (figura 17). No caso do $\mathrm{AM}$, o tempo de vida do ${ }^{1} \mathrm{O}_{2}$ ( $\tau_{\text {oxi }}$ ) foi de $77 \mu \mathrm{s}$, consistente com os valores observados para padrões não reativos, como rosa de bengala, $\left[\mathrm{Ru}(\mathrm{bipy}){ }_{3} \mathrm{Cl}_{2}\right]$. Todavia, para a $\mathrm{AgHN}_{2} \mathrm{CP}, \mathrm{CuHN}_{2} \mathrm{CP}$ e $\mathrm{H}_{2} \mathrm{~N}_{2} \mathrm{CP}$ os $\tau_{\text {oxi }}$ foram $30,12,10 \mu \mathrm{s}$, respectivamente. Além disso, a comparação dos espectros eletrônicos das amostras, antes e após os experimentos de $\phi_{\Delta}$, apresentou uma significativa diminuição nas bandas de absorção destas espécies. Estes efeitos sugerem a 
Capitulo 5.1: Porfirinas duplamente $\mathbf{N}$-confusas - Resultados e Discussões

5.1.2 - Estado Excitado Triplete e Rendimento Quântico de e ${ }^{1} \mathrm{O}_{2}$

existência de um processo de decomposição foto-induzido dos sensibilizadores. Neste caso, dois eventos distintos podem estar ocorrendo de modo isolado ou concomitante. O primeiro consiste de um processo fotoquímico em que o anel porfirínico é atacado pelo próprio ${ }^{1} \mathrm{O}_{2}$ formado. No segundo é caracterizado por um processo de foto-decomposição, ou seja, o fotossensibilizador no estado excitado torna-se suficientemente instável para que ocorram quebras de ligações ou reações com as espécies presentes em solução. Esta fotoinstabilidade somente foi observada nos experimentos, realizados em solução de acetonitrila aerada e irradiação com um laser de alta intensidade.

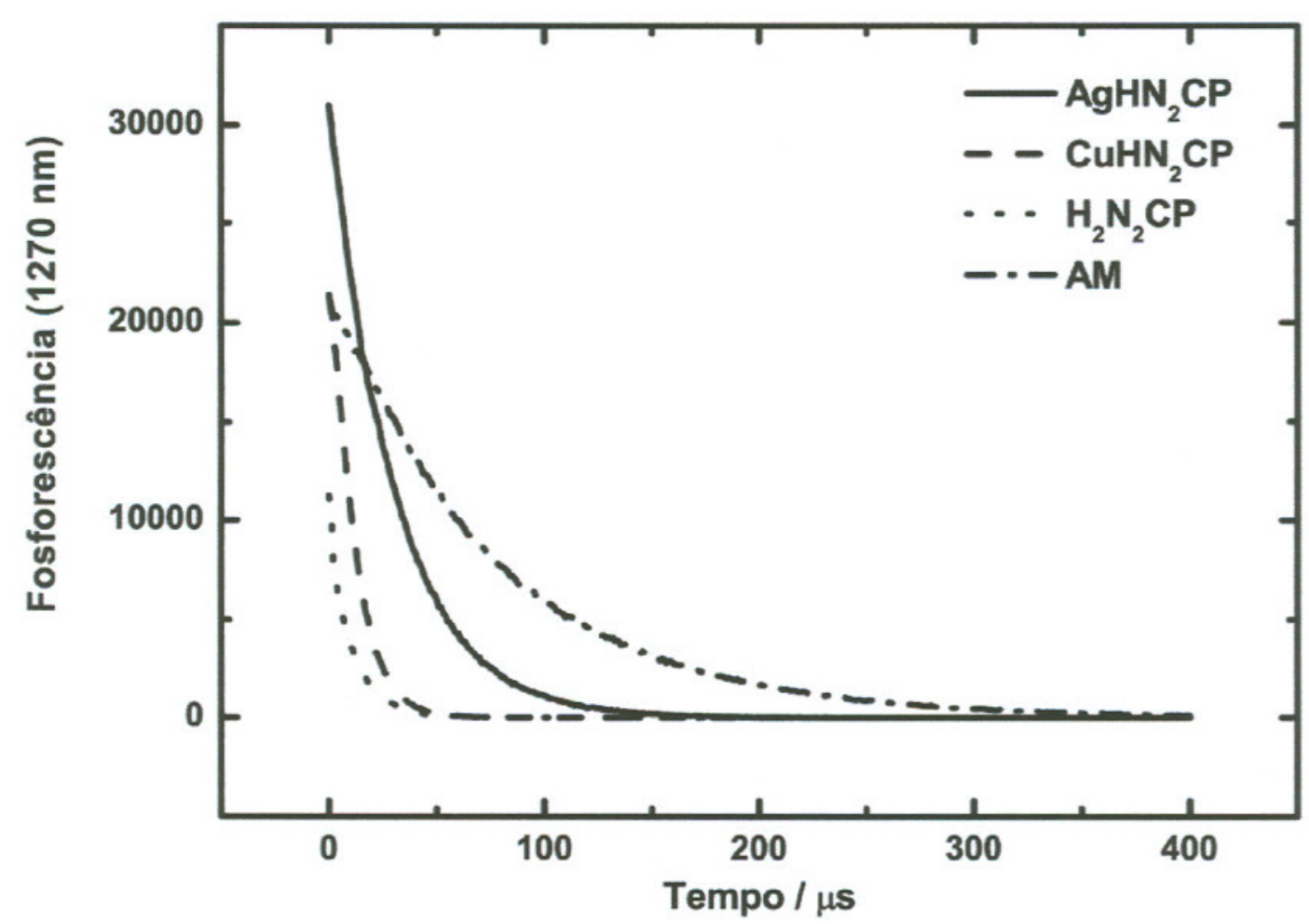

Figura 17: Curvas de fosforescência do ${ }^{1} \mathrm{O}_{2}$ em $1270 \mathrm{~nm}$ utilizando soluções em acetonitrila de $\mathrm{AgHN}_{2} \mathrm{CP}, \mathrm{CuHN}_{2} \mathrm{CP}, \mathrm{H}_{2} \mathrm{~N}_{2} \mathrm{CP}$ e $\mathrm{AM}$ (azul de metileno) como fotossensibilizador. A absorção no comprimento de onda de excitação $\left(\lambda_{\text {exc }}=532 \mathrm{~nm}\right)$ foi de 0,3 u.a. para todas as amostras. 
5.1.2 - Estado Excitado Triplete e Rendimento Quântico de ${ }^{1} \mathrm{O}_{2}$

Desta forma, os valores de $\phi_{\Delta}$ encontram-se subestimados devido ao processo de foto-decomposição acoplado. Para confirmar aqueles resultados, os $\phi_{\Delta}$ foram medidos monitorando-se a velocidade de descoramento do DFBF (1,3-difenilisobenzofurano) causado pela rápida reação com o ${ }^{1} \mathrm{O}_{2}[74]$ gerado pela excitação da porfirina. A eficiência desta reação de supressão é bastante elevada, de modo que é possivel observar a diminuição das bandas referentes ao DFBF em 310, 325 e 411 nm (figura 18), mesmo utilizando uma fonte de luz monocromática de baixa intensadade.

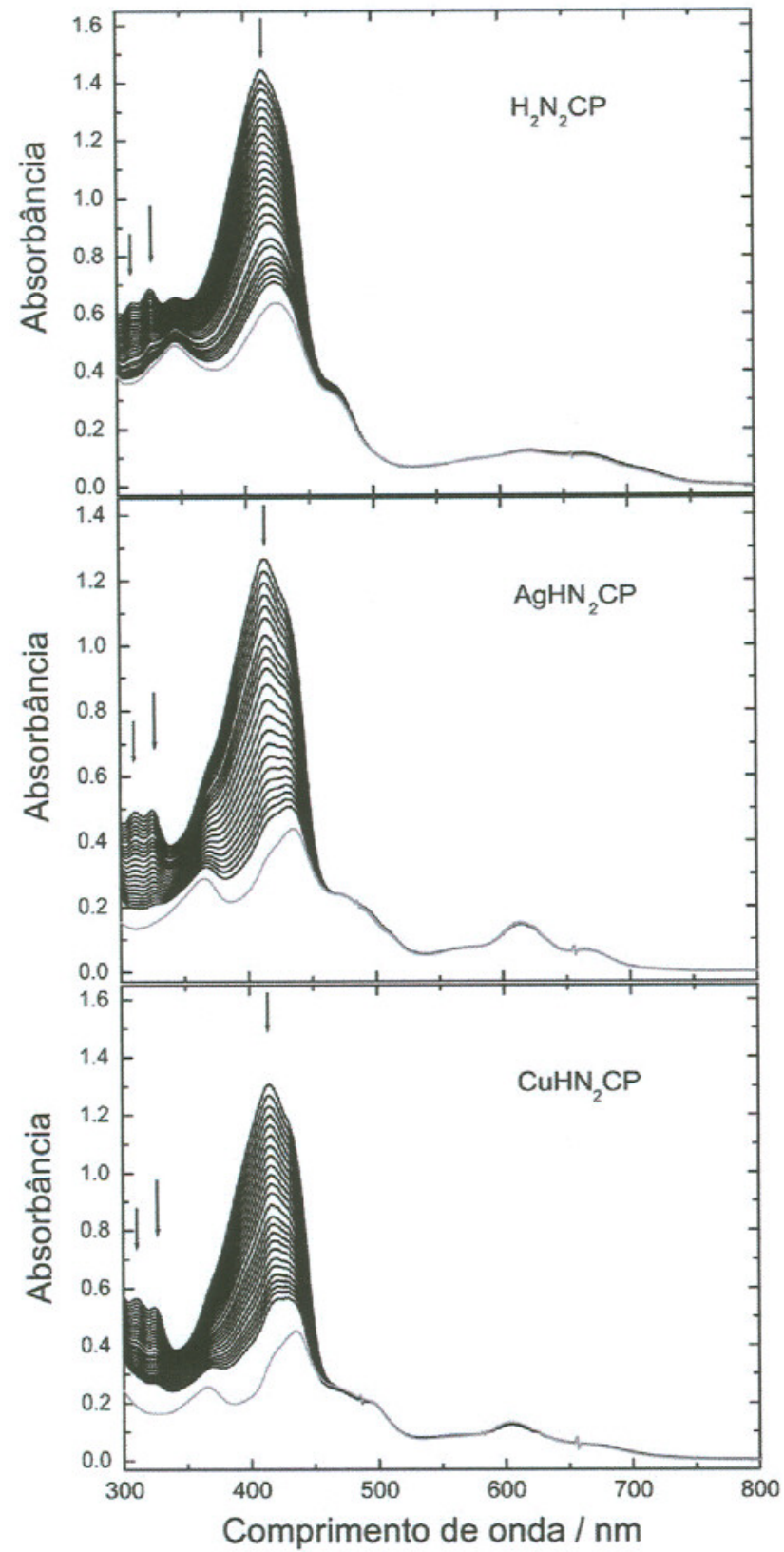

Figura 18: Diminuição das bandas de absorção do DFBF $(45 \mu \mathrm{M})$ em 310,325 e $411 \mathrm{~nm}$ utilizando a $\mathrm{H}_{2} \mathrm{~N}_{2} \mathrm{CP}$ $(14 \mu \mathrm{M}), \quad \mathrm{AgHN}_{2} \mathrm{CP}(13 \mu \mathrm{M}) \mathrm{e}$ $\mathrm{CuHN}_{2} \mathrm{CP}(10 \mu \mathrm{M}) \quad$ como fotossensibilizador $\left(\lambda_{\text {exc }}=600 \mathrm{~nm}\right)$ em solução de acetonitrila saturada de ar. $O$ espectro em cinza é referente as porfirinas antes da adição do DFBF. 
Pode-se perceber também que não é possivel observar diminuição nas bandas das porfirinas, na região de 500 a $750 \mathrm{~nm}$, indicando que estas espécies não sofrem decomposição durante a irradiação.

A eficiência do descoramento do DFBF pode ser melhor observada na figura 19, onde é mostrada a variação da absorbância do DFBF em $411 \mathrm{~nm}$ (subtraída da absorção da amostra) para cada porfirina. A velocidade de descoramento foto-induzida do DFBF é diretamente proporcional ao $\phi_{\Delta}$ do fotossensibilizador. Como esperado, o gráfico mostra que a eficiência de formação de ${ }^{1} \mathrm{O}_{2}$ segue a ordem $\mathrm{AgHN}_{2} \mathrm{CP}>\mathrm{CuHN}{ }_{2} \mathrm{CP}>\mathrm{H}_{2} \mathrm{~N}_{2} \mathrm{CP}$.

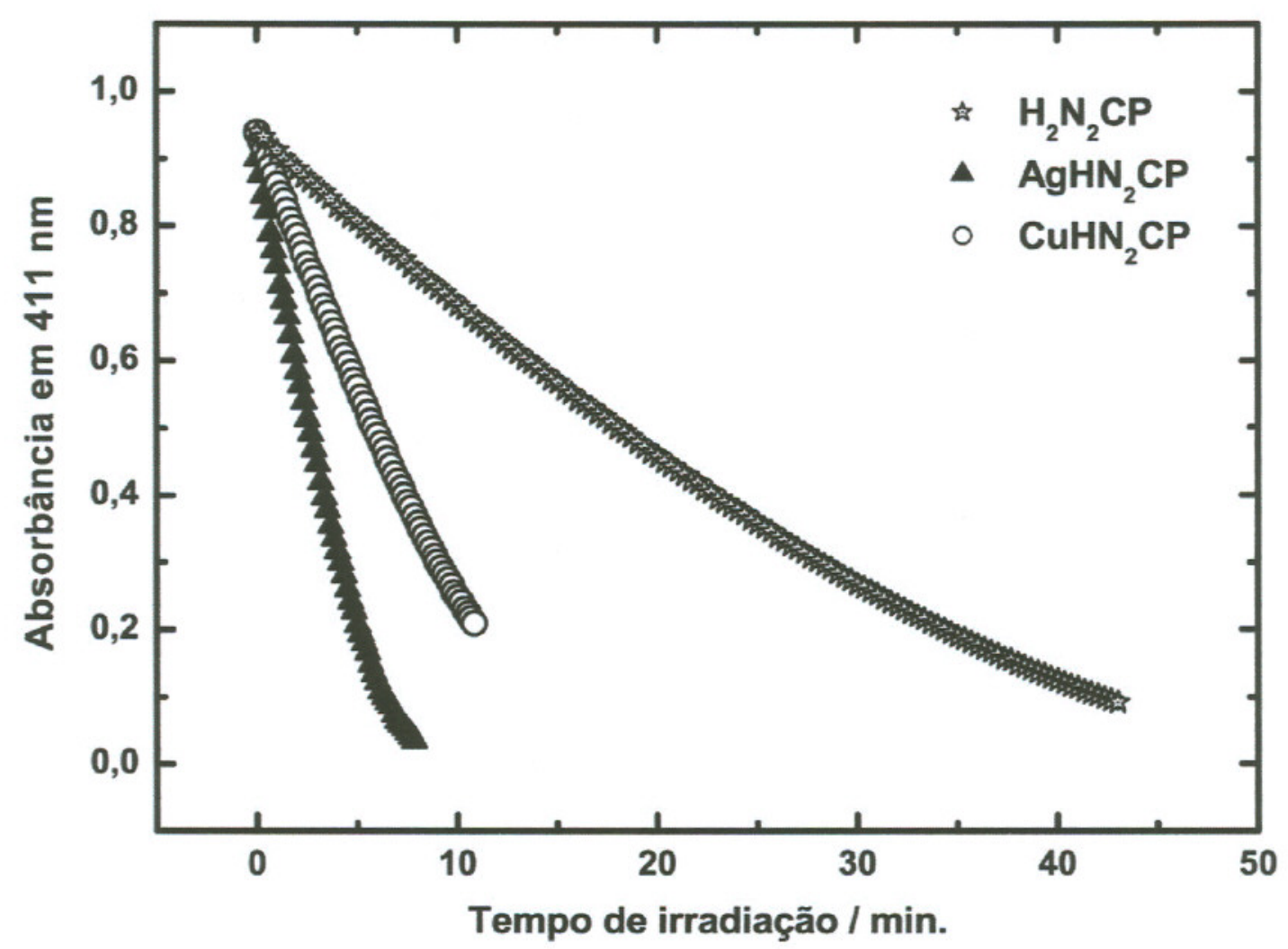

Figura 19: Gráfico mostrando a diminuição da banda em $411 \mathrm{~nm}$ da figura 18, referente a foto-decomposição do DFBF, pela irradiação $\left(\lambda_{\text {exc }}=600 \mathrm{~nm}\right)$ de uma solução de $\mathrm{H}_{2} \mathrm{~N}_{2} \mathrm{CP}, \mathrm{AgHN}_{2} \mathrm{CP}$ e $\mathrm{CuHN}_{2} \mathrm{CP}$ em acetonitrila saturada de ar. As absorbâncias foram subtraídas da absorção correspondente a banda das porfirinas. 
5.1.2 - Estado Excitado Triplete e Rendimento Quântico de ${ }^{1} \mathrm{O}_{2}$

A excitação da amostra foi realizada em dois comprimentos de onda distintos, em 480 e $600 \mathrm{~nm}$. Para isto foram utilizados dois padrões diferentes para o cálculo da intensidade de luz $\left(\mathrm{l}_{\mathrm{a}}\right)$ em cada comprimento de onda, 0 $\left[\mathrm{Ru}(\text { bipy })_{3}\right] \mathrm{Cl}_{2}\left(\phi_{\Delta}=0,80\right)$ e o azul de metileno $\left(\phi_{\Delta}=0,50\right)$, respectivamente.

Para o cálculo de $\phi_{\Delta}$ é necessário associar os dados da figura $19 \mathrm{com}$ a equação 9, de modo a obter-se o gráfico $l_{\mathrm{a}} \varepsilon_{\mathrm{DFBF}}(-\mathrm{dA} / \mathrm{dt})^{-1}$ vesus $1 / \mathrm{A}$ (figura 20), onde os coeficientes lineares das retas são inversamente proporcionais a $\phi_{\Delta}$. Tanto os valores de $\phi_{\Delta}$ obtidos por excitação em $480 \mathrm{~nm}$ como em $600 \mathrm{~nm}$ foram similares (tabela 2), mostrando que a excitação em bandas distintas conduz ao mesmo estado $T_{1}$ e com a mesma eficiência. Os resultados obtidos por este método foram semelhantes ao obtidos pelo método LIRT para a $\mathrm{H}_{2} \mathrm{~N}_{2} \mathrm{CP}$, porém para os complexos $\mathrm{Ag}(\mathrm{III})$ e $\mathrm{Cu}(\mathrm{III})$ foram significativamente maiores (14 e $60 \%$ em $\lambda_{\text {exc }}=600 \mathrm{~nm}$, respectivamente). Esta diferença deve estar associada à significativa fotodecomposição promovida pela intensa irradiação laser no caso do método LIRT. Por outro lado, verificou-se que $\mathrm{CuHN}_{2} \mathrm{CP}$ é muito mais susceptivel à reação de fotodecomposição que o $\mathrm{AgHN}_{2} \mathrm{CP}$. Este fato é consistente com os resultados acima descritos. 


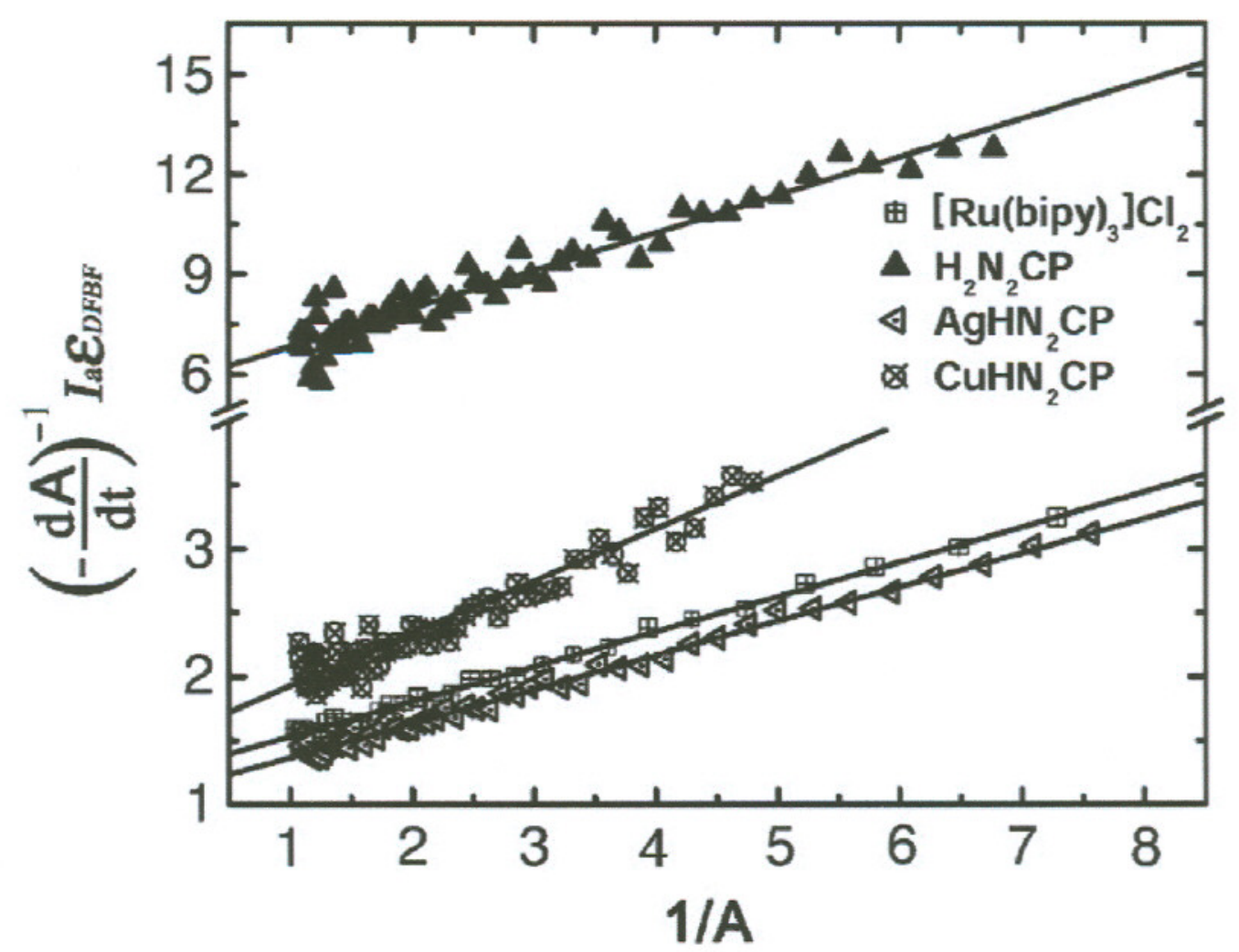

Figura 20: Gráficos do recíproco da velocidade de decomposição do DFBF versus o reciproco da absorção do DFBF, utilizando-se $\left[\mathrm{Ru}(\text { bipy })_{3}\right] \mathrm{Cl}_{2}(30 \mu \mathrm{M})$, $\mathrm{H}_{2} \mathrm{~N}_{2} \mathrm{CP}(9 \mu \mathrm{M}), \quad \mathrm{AgHN}_{2} \mathrm{CP}(8 \mu \mathrm{M})$ e $\mathrm{CuHN}_{2} \mathrm{CP}(5 \mu \mathrm{M})$ em solução de acetonitrila aerada como fotossensibilizadores. $A$ absorção dos fotossensibilizadores foi mantida em 0,3 u.a. no comprimento de onda de excitação $\left(\lambda_{\text {exc }}=480 \mathrm{~nm}\right)$. [DFBF] $=45 \mu \mathrm{M}, \mathrm{I}_{480}=1,15 \times 10^{-7} \mathrm{M} \cdot \mathrm{s}^{-1}$.

\subsubsection{ESTUDO DE FOTODECOMPOSIÇÃO}

$\mathrm{Na}$ tentativa de explorar mais detalhadamente 0 processo de fotodecomposição, observado durante a determinação de $\phi_{\Delta}$ por LIRT, foram conduzidos uma série de experimentos cinéticos para a compreensão do mecanismo de reação. 


\subsection{3 - Estudo de Fotodecomposição}

O tempo de vida do ${ }^{1} \mathrm{O}_{2}$ em solução de acetonitrila e na ausência de supressores $\left(\tau_{0}\right)$ é aproximadamente $77 \mu$ s. Nos experimentos realizados com porfirinas duplamente $\mathrm{N}$-confusas verificou-se uma diminuição de $\sim 85 \%$ no $\tau_{\text {oxi }}($ LIRT) no caso da base livre e do complexo de $\mathrm{Cu}(\mathrm{III})$., que diminuíram de daquele valor. Este comportamento é consistente com a ocorrência de uma reação competitiva de segunda ordem, onde $0{ }^{1} \mathrm{O}_{2}$ recém formado é suprimido pelo próprio fotossensibilizador. Neste caso, a determinação do $\tau_{\text {oxi, em }}$ diferentes concentrações de porfirinas, pode ser utilizada para calcular a constante de supressão bimolecular do ${ }^{1} \mathrm{O}_{2}$.

De fato, como esperado, o aumento da concentração de porfirina levou a uma elevação na quantidade de ${ }^{1} \mathrm{O}_{2}$ formado, mas também causou uma progressiva diminuição em $\tau_{\text {oxi }}$ (figura 21).

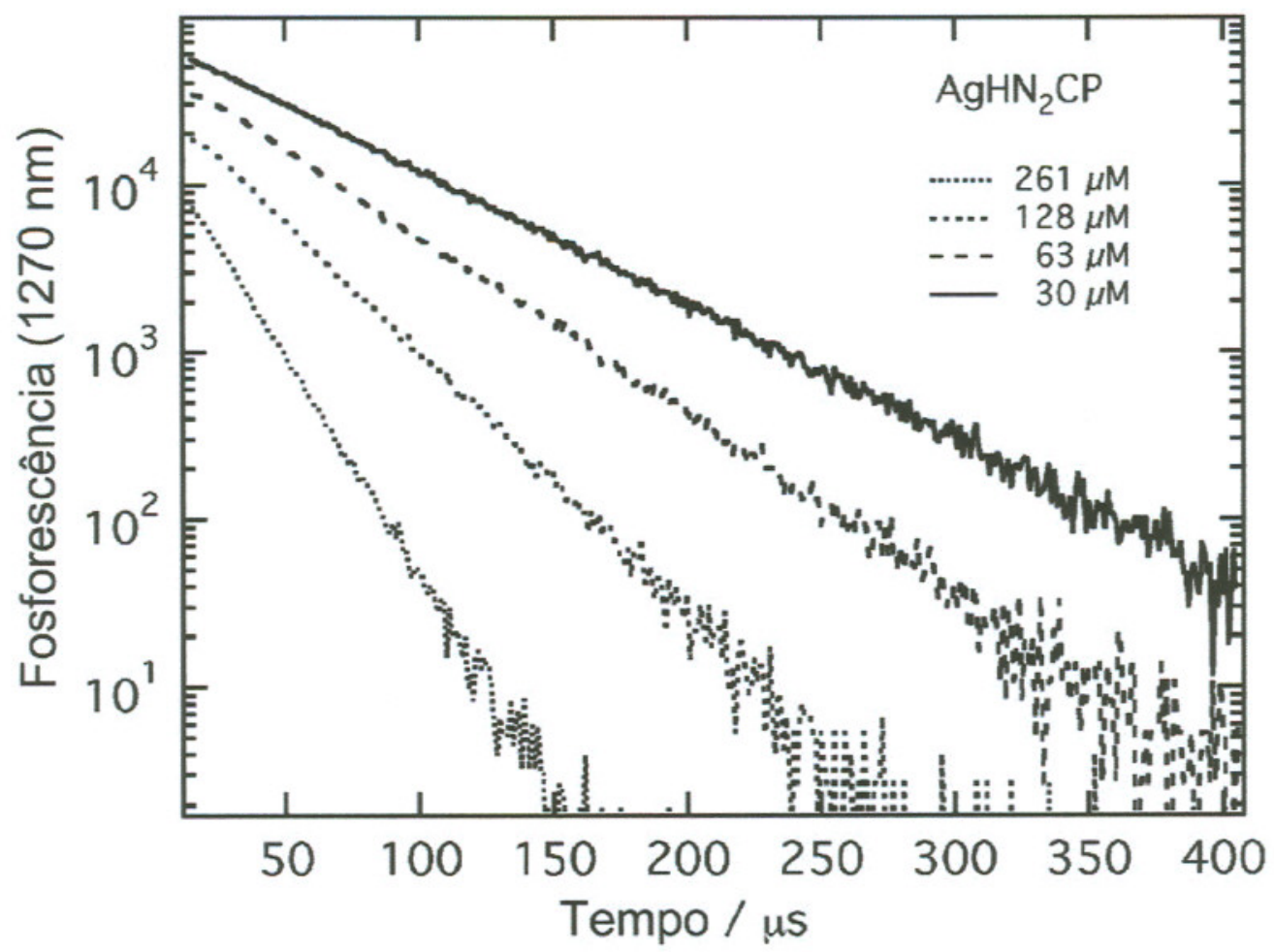

Figura 21: Curvas de decaimento (escala em $\log _{10}$ ) da emissão do ${ }^{1} \mathrm{O}_{2}$ em $1270 \mathrm{~nm}$ em função da concentração de $\mathrm{AgHN}_{2} \mathrm{CP}$, em acetonitrila. 
A constante de supressão do ${ }^{1} \mathrm{O}_{2}\left(\mathrm{k}_{\text {sup }}\right)$ para este processo pode ser calculada utilizando-se a equação de Stern-Volmer (equação 10):

$$
\text { eq. } 10 \frac{1}{\tau_{\text {oxi }}}-\frac{1}{\tau_{\text {oxi }}^{\circ}}=k_{\text {sup }}[P]
$$

onde $\tau_{\text {oxi }}^{0}$ e $\tau_{\text {oxi }}$ são os tempos de vida do ${ }^{1} \mathrm{O}_{2}$ na ausência $(77 \mu s)$ e na presença de uma determinada concentração de porfirina ([P]).

Os valores de $k_{\text {sup }}$ (tabela 2 ) obtidos foram bastante elevados indicando que o processo é muito eficiente e que é limitado apenas pela constante de difusão das espécies no meio $\left(\sim 10^{9} \mathrm{~s}^{-1}\right)$.

Como esperado, o complexo de $\mathrm{Cu}(\mathrm{III})$ apresentou o maior valor de $\mathrm{k}_{\text {sup}}$, seguido da base livre e da $\mathrm{Ag}(\mathrm{III})$. Este perfil corrobora os resultados anteriores confirmando as suspeitas de maior instabilidade fotoquimica da $\mathrm{CuHN}_{2} \mathrm{CP}$. $\dot{\mathrm{E}}$ interessante perceber ainda que as formas aniônicas foram mais eficientemente atacadas pelo ${ }^{1} \mathrm{O}_{2}$ que as catiônicas. Este resultado era esperado em virtude de sítios ricos em elétrons, como duplas ligações, serem alvos preferenciais para o ataque do oxigênio singlete.

A instabilidade fotoquímica da $\mathrm{H}_{2} \mathrm{~N}_{2} \mathrm{CP}, \mathrm{AgHN} \mathrm{N}_{2} \mathrm{CP}$ e CuHN $\mathrm{N}_{2} \mathrm{CP}$ também foram avaliadas monitorando-se os espectros eletrônicos das soluções em função do tempo de irradiação, utilizando uma lâmpada de xênonio (150 W, página 28). Os experimentos também foram conduzidos em diferentes concentrações de oxigênio dissolvido.De um modo geral, a irradiação da solução causou uma diminuição de intensidade das bandas de absorção na região de 350 a 500 e de 600 a $750 \mathrm{~nm}$ e o surgimento de duas novas bandas em 320 e 540 nm (figura 22). A velocidade de desaparecimento destas bandas foi proporcional à concentração de oxigênio dissolvido. Ou seja, os espectros de absorção das amostras mantiveram-se constantes quando as soluções foram saturadas com gás nitrogênio ou argônio (figura 23). Porém, uma pequena quantidade de oxigênio que se difunde através do septo demonstrou ser suficiente para promover a diminuição da absorbância. Neste caso, não foi possivel usar supressores de oxigênio singlete, como azida de sódio e 
5.1.3 - Estudo de Fotodecomposição

DABCO (1,4-diazabiciclo[2,2,2]-octane), para proteger o composto porque eles são suficientemente básicos para desprotonar o anel.

Este perfil indica claramente que a foto-instabilidade é um processo químico, envolvendo $\mathrm{o}^{1} \mathrm{O}_{2}$. Além disso, a participação concomitante de um processo de autodecomposição pode ser excluida, devido a ausência de alterações espectrais em ambiente inerte de nitrogênio ou argônio. A semelhança nas variações das bandas durante a irradiação e no espectro como um todo após o processo parece indicar que os fotoprodutos gerados são similares (figura 22).
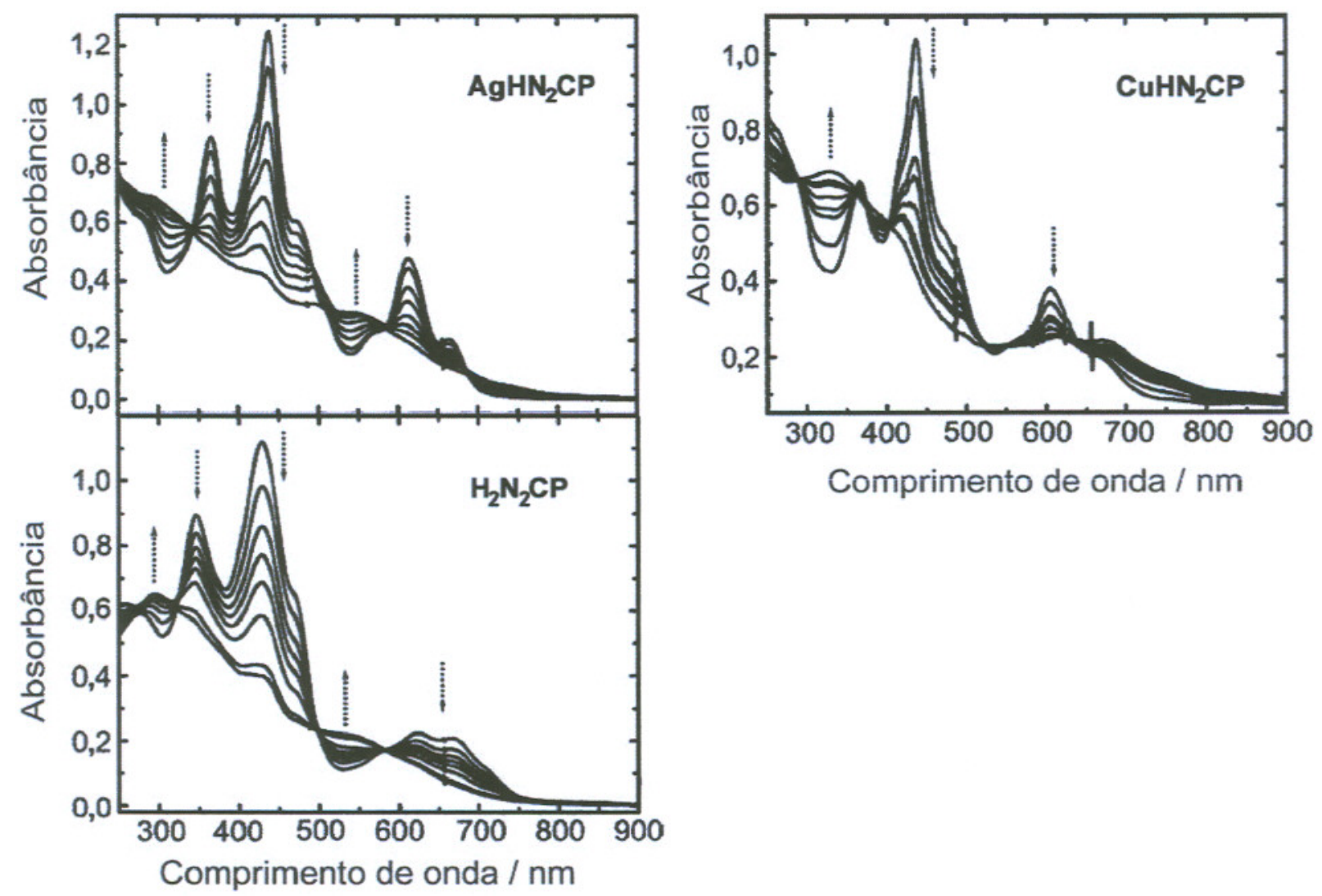

Figura 22: Variações das bandas de absorção para soluções de $\mathrm{AgHN}_{2} \mathrm{CP}$ (durante $45 \mathrm{~min}$.), $\mathrm{H}_{2} \mathrm{~N}_{2} \mathrm{CP}$ (durante 45 min.) e CuHN $\mathrm{N}_{2} \mathrm{CP}$ (durante 10 min.) em acetonitrila saturada de $\mathrm{O}_{2}$ e sob constante irradiação $\left(300 \mathrm{~nm}<\lambda_{\text {exc }}<700 \mathrm{~nm}\right)$. 
5.1.3 - Estudo de Fotodecomposição

A maior reatividade do complexo de $\mathrm{Cu}$ (III) toma-se ainda mais evidente quando se observar a curva cinética, mostrada na figura 23 (direita inferior). Neste caso, a amostra foi completamente decomposta em 10 minutos enquanto que a base livre e o complexo de $\mathrm{Ag}$ (III) requereram um tempo superior a 45 minutos, nas mesmas condições, ou seja, soluções saturadas de $\mathrm{O}_{2}$ e mesma potência de irradiação.
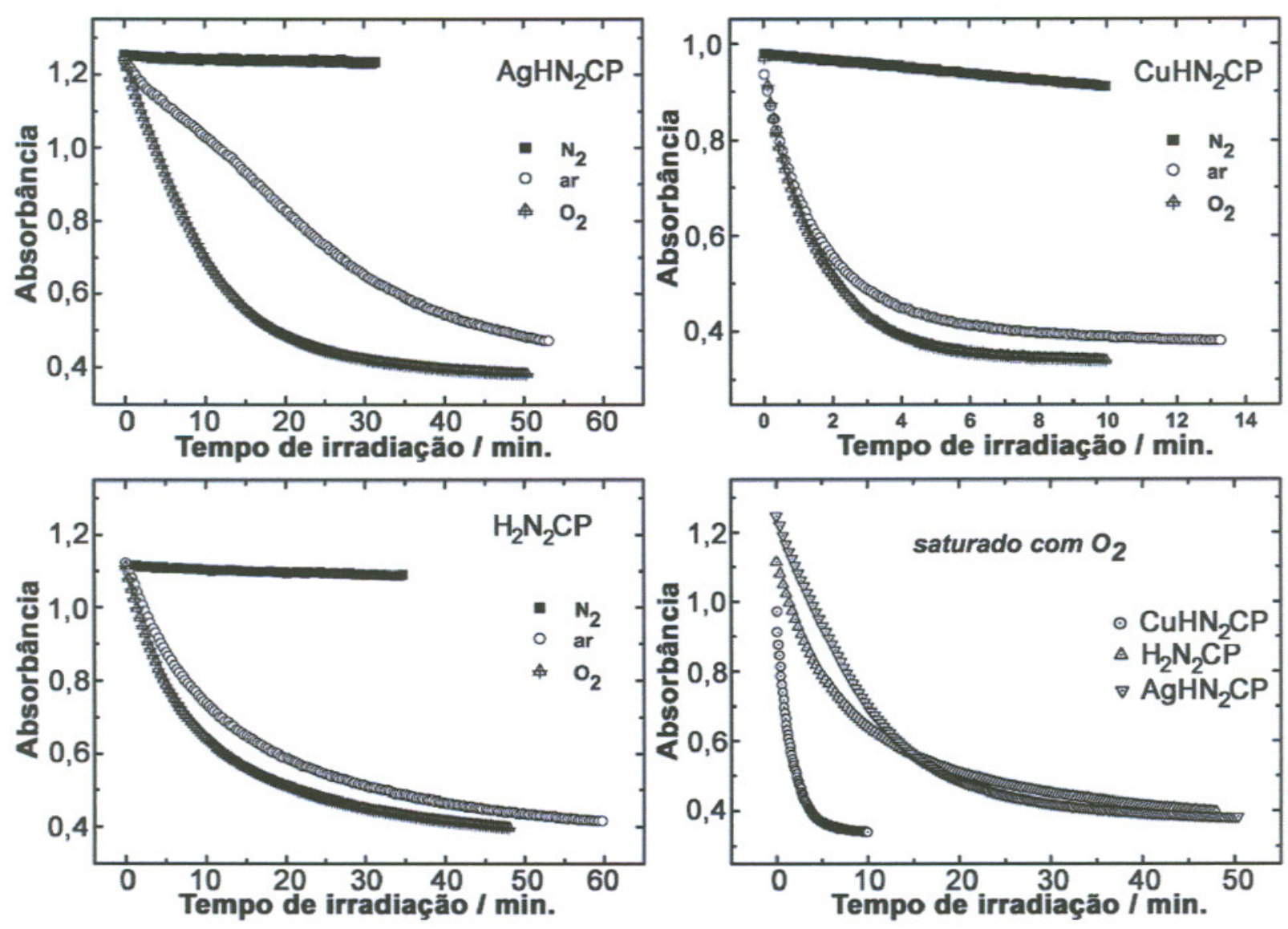

Figura 23: Curvas cinéticas obtidas monitorando-se a absorção da $\mathrm{AgHN}_{2} \mathrm{CP}(438 \mathrm{~nm}), \mathrm{H}_{2} \mathrm{~N}_{2} \mathrm{CP}(427 \mathrm{~nm})$ e $\mathrm{CuHN}_{2} \mathrm{CP}(438 \mathrm{~nm})$ em solução de acetonitrila saturadas com gás $\mathrm{N}_{2}$, ar e $\mathrm{O}_{2}$, sob irradiação constante (300 nm $<\lambda_{\text {exc }}<700 \mathrm{~nm}$ ). No gráfico do canto inferior direito estão as curvas em solução saturada de $\mathrm{O}_{2}$ das três amostras para comparação. 
A tentativa de ajustar estas curvas com uma exponencial de primeira ordem não foi satisfatória. Somente a utilização de uma bi-exponencial ou ainda de duas funções mono-exponenciais foram necessárias para ajustar as curvas experimentais. Este comportamento parece sugerir a ocorrência de pelo menos duas reações de decomposição sucessivas. De fato, na condição de saturação de $\mathrm{O}_{2}$, as constantes de velocidade calculadas para estes processos mostraram a presença de um evento inicial mais rápido, seguido de outro mais lento $\left(\mathrm{CuHN}_{2} \mathrm{CP}\left(8,3 \times 10^{-2}\right.\right.$ e $\left.9,8 \times 10^{-3} \mathrm{~s}^{-1}\right)$ e $\mathrm{H}_{2} \mathrm{~N}_{2} \mathrm{CP}\left(3,6 \times 10^{-3}\right.$ e $\left.\left.9,2 \times 10^{-4} \mathrm{~s}^{-1}\right)\right)$.

O comportamento geral observado para a $\mathrm{AgHN}_{2} \mathrm{CP}$ foi similar, mas a curva cinética pode somente ser aproximada por duas exponenciais. Além disso, o primeiro processo foi mais lento que o segundo $\left(9,8 \times 10^{-4}, 2,1 \times 10^{-3} \mathrm{~s}^{-1}\right.$, respectivamente), sugerindo que o mecanismo de reação é precedido por um processo de indução.

\subsection{CONCLUSÃO}

As porfirinas cis duplamente $\mathrm{N}$-confusas base livre $\left(\mathrm{H}_{2} \mathrm{~N}_{2} \mathrm{CP}\right)$ e os complexos de $\mathrm{Cu}$ (III) $\left(\mathrm{CuHN}_{2} \mathrm{CP}\right)$ e $\mathrm{Ag}$ (III) $\left(\mathrm{AgHN}_{2} \mathrm{CP}\right)$ apresentam elevada absorção em toda a região do espectro visivel, particularmente na região da 600 a $750 \mathrm{~nm}$. Somente a $\mathrm{H}_{2} \mathrm{~N}_{2} \mathrm{CP}$ apresentou fluorescência. Associado a este aspecto, a metalação parece ter intensificado a eficiência de cruzamento interssistema $\left(\phi_{\text {cis }}\right)$ ao invés de suprimir a espécie no estado excitado, como confirmado pelo aumento do rendimento quântico de $\phi_{\Delta}$. A desprotonação das porfirinas não influencia significativamente as propriedades fotofisicas, mas a protonação leva a uma maior eficiência de relaxação térmica, tanto do estado $S_{1}$ quanto do $T_{1}$, desfavorecendo os demais processos.

$\mathrm{O}$ rendimento quântico de formação de ${ }^{1} \mathrm{O}_{2}$ obtidos utilizando-se uma fonte de luz menos intensa foram maiores, sugerindo a ocorrência concomitante de um processo de fotodecomposição. Estudos detalhados foram realizados de modo a confirmar a natureza do processo de 
fotodecomposição daqueles fotossensibilizadores porfirínicos. De fato, 0 descoramento da solução irradiada somente foi observado em soluções contente oxigênio dissolvido e sob irradiação. Este comportamento é consistente com um mecanismo químico envolvendo a reação do fotossensibilizador com $\circ{ }^{1} \mathrm{O}_{2}$ fotoquimicamente formado. As constantes de supressão do ${ }^{1} \mathrm{O}_{2}$ pelo corante e as constantes de velocidade dos processos de fotodecomposição mostraram que a $\mathrm{CuHN}_{2} \mathrm{CP}$ é a espécie fotoquímicamente mais reativa enquanto que a $\mathrm{AgHN}_{2} \mathrm{CP}$ é a mais estável.

Em suma, os resultados mostraram que a $\mathrm{Ag}$ (III) é um excelente gerador de ${ }^{1} \mathrm{O}_{2}$, sendo o derivado mais interessante desta série para ser estudado como fotossensibilizador em terapia fotodinâmica. Associado a um elevadissimo $\phi_{\Delta}(>0,90)$ a $\mathrm{AgHN}_{2} \mathrm{CP}$ é relativamente estável, mas também apresenta um processo de fotodecomposição que pode acelerar sua eliminação do organismo, como no caso do Visudyne ${ }^{\circledR}$. 


\section{MESO-(PIRIDIL)FENILPORFIRINAS}

\subsection{RESULTADOS E DISCUSSÕES}

\subsubsection{SÍNTESE E PURIFICAÇÃO DAS MESO-(PIRIDIL)FENILPORFIRINAS}

A série das meso-(3-piridil)fenilporfirinas (3S) contendo zero, um, dois, três e quatro substituintes piridil foram preparadas segundo procedimento adotado para a série das meso-(4-piridil)fenilporfirinas (4S) [73]. $O$ método descrito por Fleischer e colaboradores [70] consiste na reação estatistica entre pirrol e dois aldeídos, o benzaldeido e $\circ$ 3-piridilcarboxaldeído ou $\circ$ 4piridilcarboxaldeído, sob refluxo em ácido propiônico.

O mecanismo da sintese (figura 24) inicia-se pelo ataque eletrofilico do aldeído, em meio ácido, sobre a posição $\alpha$ do pirrol levando à formação de um carbocátion. Esta espécie reage sucessivamente com 3 outros carbocátions análogos até formarem um anel, denominado porfirinogênio. $O$ oxigênio molecular dissolvido na solução oxida rapidamente o porfirinogênio formando a porfirina.

À medida que a reação evoluiu, a coloração da solução passou de incolor para vinho e ao final de 1,5 horas de refluxo, a mistura tornou-se totalmente preta. O solvente então foi removido no evaporador rotatório até formar uma massa viscosa. A esta foram adicionados, sob agitação, $100 \mathrm{~mL}$ de uma mistura de DMF/ETOH 1:1 e então a solução foi mantida em repouso por algumas horas sob refrigeração. Esta mistura de solventes é suficiente para solubilizar a maior parte dos subprodutos escuros que foram gerados na reação, mas as meso-( $N$-piridil)fenilporfirinas permanecem pouco solúveis. Em seguida, a suspensão foi filtrada em funil de placa sinterizada e lavada com a mistura de DMF/ETOH 1:1 até a coloração preta inicial do filtrado desaparecer, restando no funil um sólido de coloração violeta brilhante. 
6.1.1 - Síntese e purificação das meso-(piridil)fenilporfirinas<smiles>[R]C([18OH])c1ccc[nH]1</smiles>

PIRROL<smiles>[R]C([OH2+])c1ccc[nH]1</smiles><smiles></smiles>

PORFIRINOGÊNIO<smiles></smiles>

3-PIRIDIL

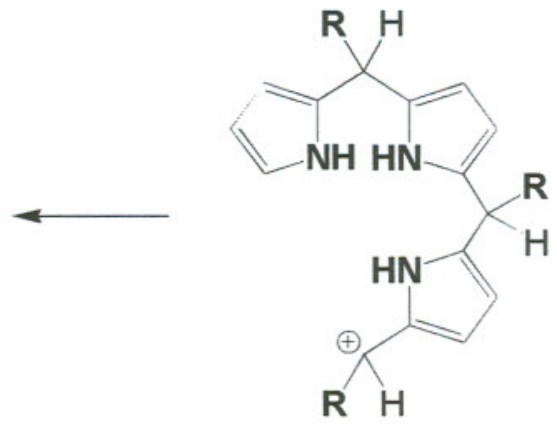

R $\mathrm{H}$

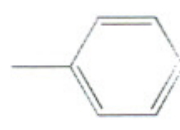

FENIL

Figura 24: Mecanismo da reação de formação do porfirinogênio.

As etapas seguintes consistiram na purificação e separação das seis porfirinas por cromatografia em coluna, utilizando uma mistura de diclorometano e etanol $(98: 2 \mathrm{v} / \mathrm{v})$ como fase móvel e silica gel como fase estacionária. As 6 primeiras frações de cada série de porfirinas foram caracterizadas por ${ }^{1} \mathrm{H}$ RMN e COSY e corresponderam respectivamente a TPP, 3P, $3 \mathrm{P}_{2 \mathrm{t}}, 3 \mathrm{P}_{2 \mathrm{c}}, 3 \mathrm{P}_{3}$ e $3 \mathrm{P}_{4}$, respectivamente. 


\subsubsection{SÍNTESE E PURIFICAÇÃO DAS MESO-(N- METILPIRIDÍNIO)FENILPORFIRINAS}

Os derivados $\mathrm{N}$-metilpiridínio foram obtidos pelo refluxo das porfirinas 3S e 4S correspondentes com excesso de tosilato de metila em DMF, por 4 horas. Em seguida, a maior parte do solvente foi removido no evaporador rotatório sob vácuo e a solução restante foi gotejada sobre uma solução aquosa contendo $\mathrm{NaPF}_{6}$ (hexafluorofosfato de sódio) para promover a precipitação da porfirina metilada. $\mathrm{O}$ sólido violeta foi filtrado e lavado várias vezes com água.

Apesar do maior impedimento estérico, a metilação dos nitrogênios pirrólicos também é possivel se a concentração de tosilato de metila for muito elevada e o tempo de reação for suficientemente longo. Para evitar este inconveniente, as condições experimentais foram selecionadas de modo a minimizar ou excluir a ocorrência dessa reação. Neste caso, o deslocamento da banda Soret e bandas Q's para menor energia na presença de $\mathrm{HCl}$ ou acetado de zinco, foram consideradas provas satisfatórias da ausência de metilação nestes pontos.

Com a finalidade de tornar as amostras mais solúveis em meio aquoso, o contra-ion destas porfirinas catiônicas foi trocado de $\mathrm{PF}_{6}{ }^{-}$para $\mathrm{Cl}^{-}$, através de precipitação em acetona. Para isso, soluções concentradas das $3 \mathrm{SMe} e$ 4SMe, dissolvidas em DMF, foram gotejadas sobre uma solução saturada de $\mathrm{LiCl} \mathrm{em} \mathrm{acetona.} \mathrm{Este} \mathrm{procedimento} \mathrm{levou} \mathrm{a} \mathrm{formação} \mathrm{imediata} \mathrm{de} \mathrm{um} \mathrm{sólido}$ marrom avermelhado que foi filtrado e lavado várias vezes com acetona para remover o excesso de LiCl.

Os espectros eletrônicos das porfirinas $3 \mathrm{~S}$ e $4 \mathrm{~S}$ em diclorometano são muito semelhantes, tanto no que se refere às energias das transições como nas intensidades das bandas de absorção. Todavia, a metilação das piridinas promove um maior deslocamento batocrômico da banda Soret da $4 \mathrm{SMe}\left(422 \mathrm{~nm}\right.$ para a $\left.4 \mathrm{P}_{4} \mathrm{Me}\right)$ em relação à $3 \mathrm{SMe}\left(417 \mathrm{~nm}\right.$ para a $\left.3 \mathrm{P}_{4} \mathrm{Me}\right)$, como mostrado na figura 25. O mesmo perfil de deslocamento pode ser observado nas bandas Q's, que para a $3 \mathrm{P}_{4} \mathrm{Me}$ são encontradas em 515,551 , 
6.1.2 - Síntese e purificação das meso-(metilpiridínio)fenilporfirinas

584 e $638 \mathrm{~nm}$ e para a para a 4P4Me em 518, 550, 585 e $638 \mathrm{~nm}$. A 4SMe também passa a apresentar uma banda Soret com menor intensidade e mais alargada em relação à 3SMe.

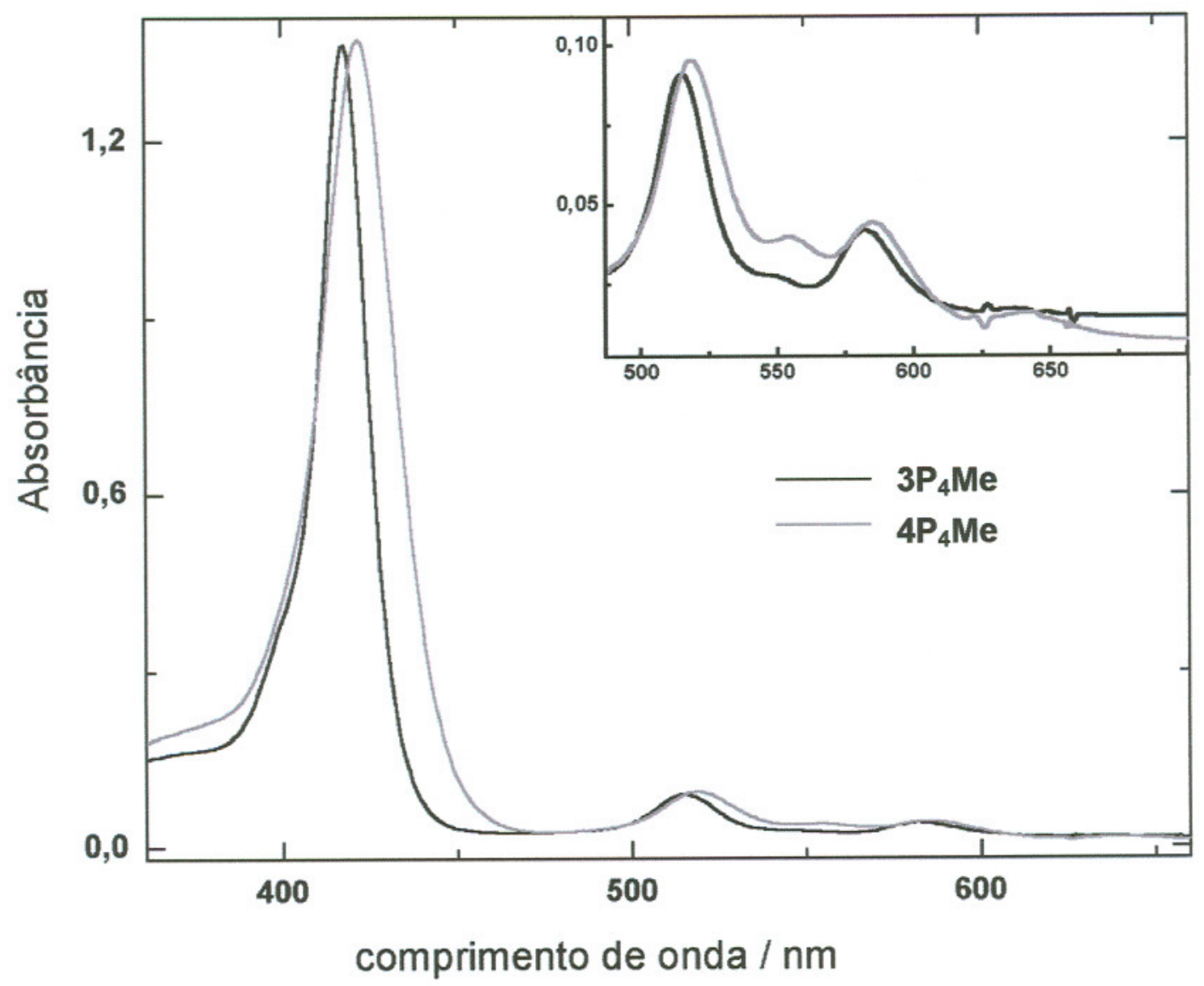

Figura 25: Espectro UV-vis da $3 \mathrm{P}_{4} \mathrm{Me}$ e $4 \mathrm{P}_{4} \mathrm{Me}$ em água.

Analisando a absortividade molar da banda Soret para as formas neutras e ácidas, compiladas a seguir, pode-se perceber que a intensidade da banda Soret para a 3 SMe é cerca de $30 \%$ maior que para a $4 \mathrm{SMe}$. Este comportamento pode ser um indício de uma menor comunicação eletrônica entre o anel e os resíduos metilpiridínio no caso das 3SMe. 
A caracterização por ${ }^{1} \mathrm{H}$ RMN e COSY mostrou estar de acordo com as atribuições de Meng [71,83]. Além disso, as áreas integradas sobre dos picos e a ausência de sinais que não fosse das estruturas estudas, indicam que as amostras não apresentam misturas de isômeros nem contaminações com os reagentes de partida. De modo que as amostras foram consideradas puras para as aplicações desejadas.

3PMe: ${ }^{1} \mathrm{H}$ RMN (acetona $\left.\mathrm{d}_{\mathrm{d}}\right): \quad \delta=10,08(\mathrm{~s}, 1 \mathrm{H}), \quad 9,63(\mathrm{~d}, 1 \mathrm{H}), \quad 9,54(\mathrm{~d}, 1 \mathrm{H})$, $8,95(\mathrm{~m}, 8 \mathrm{H}), 8,76(\mathrm{t}, 1 \mathrm{H}), 8,25(\mathrm{~d}, 6 \mathrm{H}), 7,85(\mathrm{~m}, 9 \mathrm{H}), 4,99(\mathrm{~s}, 3 \mathrm{H}) \mathrm{e}-$ 2,80 ppm (s, 2H); Amostra insolúveis em água.

3P $\mathbf{P}_{2 \mathrm{t}}$ Me: ${ }^{1} \mathrm{H}$ RMN (DMSO $\left.{ }_{\mathrm{d} 6}\right): \delta=9,99(\mathrm{~d}, 2 \mathrm{H}), 9,48$ (d, 2H), 9,37 (pico largo, 2H), $9,08(\mathrm{~d}, 4 \mathrm{H}), 8,95(\mathrm{~d}, 4 \mathrm{H}), 8,58(\mathrm{t}, 2 \mathrm{H}), 8,22(\mathrm{~d}, 4 \mathrm{H}), 7,89(\mathrm{~m}, 6 \mathrm{H}), 4,65(\mathrm{~s}, 6 \mathrm{H}) \mathrm{e}$ $-3,00 \mathrm{ppm}(\mathrm{s}, 2 \mathrm{H}) ; \varepsilon_{417 \mathrm{~nm}}=2,4 \times 10^{5}$ e $\varepsilon^{\mathrm{H+}}{ }_{437 \mathrm{~nm}}=2,7 \times 10^{5} \mathrm{M}^{-1} \cdot \mathrm{cm}^{-1}$.

3P $\mathbf{P}_{2 \mathrm{c}} \mathrm{Me}:{ }^{1} \mathrm{H}$ RMN (acetona $\left.\mathrm{d}_{\mathrm{d}}\right): \delta=10,07(\mathrm{~s}, 2 \mathrm{H}), 9,59(\mathrm{~d}, 2 \mathrm{H}), 9,50(\mathrm{~d}, 2 \mathrm{H})$, $9,05(\mathrm{~m}, 8 \mathrm{H}), 8,73(\mathrm{t}, 2 \mathrm{H}), 8,26(\mathrm{~d}, 4 \mathrm{H}), 7,87(\mathrm{~m}, 6 \mathrm{H}), 4,96(\mathrm{~s}, 6 \mathrm{H}) \mathrm{e}-$ $2,84 \mathrm{ppm}(\mathrm{s}, 2 \mathrm{H}) ; \varepsilon_{417 \mathrm{~nm}}=2,0 \times 10^{5}$ e $\varepsilon^{\mathrm{H+}}{ }_{437 \mathrm{~nm}}=2,4 \times 10^{5} \mathrm{M}^{-1} \cdot \mathrm{cm}^{-1}$.

3P $\mathbf{P}_{3}$ Me: ${ }^{1} \mathrm{H}$ RMN (acetona $\left.\mathrm{d} 6\right): \quad \delta=10,09(\mathrm{~s}, 3 \mathrm{H}), 9,60(\mathrm{~m}, 3 \mathrm{H}), 9,51(\mathrm{~m}, 3 \mathrm{H})$, $9,14(\mathrm{~m}, 8 \mathrm{H}), 8,74(\mathrm{~m}, 3 \mathrm{H}), 8,26(\mathrm{~d}, 2 \mathrm{H}), 7,90(\mathrm{~m}, 3 \mathrm{H}), 4,96(\mathrm{~s}, 6 \mathrm{H}), 4,94(\mathrm{~s}, 3 \mathrm{H})$ e $-2,90 \mathrm{ppm}(\mathrm{s}, 2 \mathrm{H}) ; \varepsilon_{417 \mathrm{~nm}}=2,4 \times 10^{5}$ e $\varepsilon^{\mathrm{H}+}{ }_{437 \mathrm{~nm}}=2,5 \times 10^{5} \mathrm{M}^{-1} \cdot \mathrm{cm}^{-1}$.

3P 4 Me: ${ }^{1} \mathrm{H}$ RMN (acetona $\left.\mathrm{d}_{6}\right): \quad \delta=10,07(\mathrm{~s}, 4 \mathrm{H}) ; 9,61(\mathrm{~d}, 4 \mathrm{H}) ; 9,49(\mathrm{~d}, 4 \mathrm{H})$; $9,24(\mathrm{~s}, 8 \mathrm{H}), 8,73(\mathrm{t}, 4 \mathrm{H}), 4,93(\mathrm{~s}, 12 \mathrm{H})$ e $-2,99 \mathrm{ppm}(\mathrm{s}, 2 \mathrm{H}) ; \varepsilon_{417 \mathrm{~nm}}=2,6 \times 10^{5}$ e $\varepsilon^{\mathrm{H}+}{ }_{437 \mathrm{~nm}}=3,0 \times 10^{5} \mathrm{M}^{-1} \cdot \mathrm{cm}^{-1}$.

4PMe: ${ }^{1} \mathrm{H}$ RMN (DMSO $\left.\mathrm{d} 6\right): \quad \delta=9,33(\mathrm{~d}, \quad 2 \mathrm{H}), \quad 8,91(\mathrm{~m}, \quad 10 \mathrm{H}), \quad 8,18(\mathrm{~d}, 6 \mathrm{H})$, $7,83(\mathrm{~m}, 9 \mathrm{H}), 4,66(\mathrm{~s}, 3 \mathrm{H})$ e $-2,97 \mathrm{ppm}(\mathrm{s}, 2 \mathrm{H})$. Insolúveis em água.

4P ${ }_{2 t}$ Me: ${ }^{1} \mathrm{H}$ RMN (DMSO $\left.d 6\right): \delta=9,47(d, 4 H), 9,01(d, 8 H), 8,96(d, 4 H), 8,23$ (d, $4 \mathrm{H}), 7,88(\mathrm{~m}, 6 \mathrm{H}), 4,69(\mathrm{~s}, 6 \mathrm{H})$ e $-2,98 \mathrm{ppm}(\mathrm{s}, 2 \mathrm{H}) ; \varepsilon_{425 \mathrm{~nm}}=1,8 \times 10^{5} \mathrm{e}$ $\varepsilon^{\mathrm{H}+}{ }_{455 \mathrm{~nm}}=2,05 \times 10^{5} \mathrm{M}^{-1} \cdot \mathrm{cm}^{-1}$. 
6.1.3 - Síntese e purificação das meso-(piridil)fenilporfirinas rutenadas

$\mathbf{4 P}_{2 \mathrm{c}} \mathrm{Me}:{ }^{1} \mathrm{H}$ RMN (DMSO $\left.{ }_{\mathrm{d} 6}\right): \quad \delta=9,43(\mathrm{~d}, 4 \mathrm{H}), \quad 9,01(\mathrm{~m}, 12 \mathrm{H}), \quad 8,23(\mathrm{~d}, 4 \mathrm{H})$, $7,86(\mathrm{~m}, 6 \mathrm{H}), \quad 4,69(\mathrm{~s}, \quad 6 \mathrm{H})$ e $-2,96 \mathrm{ppm}(\mathrm{s}, \quad 2 \mathrm{H}) ; \quad \varepsilon_{425 \mathrm{~mm}}=1,1 \times 10^{5}$ e $\varepsilon^{\mathrm{H}+}{ }_{455 \mathrm{~nm}}=1,5 \times 10^{5} \mathrm{M}^{-1} \cdot \mathrm{cm}^{-1}$.

4P $\mathbf{P}_{3} \mathrm{Me}:{ }^{1} \mathrm{H}$ RMN $\left(\mathrm{DMSO}_{\mathrm{d}}\right): \quad \delta=9,51(\mathrm{~d}, 6 \mathrm{H}), \quad 9,10(\mathrm{~m}, 14 \mathrm{H}), \quad 8,24(\mathrm{~d}, 2 \mathrm{H})$, $7,88(\mathrm{~m}, \quad 3 \mathrm{H}), \quad 4,73(\mathrm{~s}, \quad 9 \mathrm{H})$ e $-3,01 \mathrm{ppm}(\mathrm{s}, \quad 2 \mathrm{H}) ; \boldsymbol{\varepsilon}_{425 \mathrm{~nm}}=1,5 \times 10^{5}$ e $\varepsilon^{\mathrm{H+}}{ }_{455 \mathrm{~nm}}=1,7 \times 10^{5} \mathrm{M}^{-1} \cdot \mathrm{cm}^{-1}$

4P 4 Me: ${ }^{1} \mathrm{H}$ RMN (DMSO $\left.{ }_{\mathrm{d} 6}\right): \delta=9,48(\mathrm{~d}, 8 \mathrm{H}), 9,18(\mathrm{~s}, 8 \mathrm{H}), 8,87(\mathrm{~d}, 8 \mathrm{H}), 4,72(\mathrm{~s}$, $12 \mathrm{H})$ e $-3,10 \mathrm{ppm}(\mathrm{s}, 2 \mathrm{H}) ; \varepsilon_{425 \mathrm{~nm}}=1,8$ e $\varepsilon^{\mathrm{H+}}{ }_{455 \mathrm{~nm}}=2,3 \times 10^{5} \mathrm{M}^{-1} \cdot \mathrm{cm}^{-1}$.

\subsubsection{SÍNTESE E PURIFICAÇÃO DAS MESO-(PIRIDIL)FENILPORFIRINAS RUTENADAS}

A obtenção das espécies supramoleculares, quer seja na preparação ou nas etapas de purificação, é muito mais trabalhosa que no caso anterior. Por exemplo, a eliminação do excesso do complexo de rutênio de partida requer uma purificação mais criteriosa por cromatografia em coluna.

O procedimento para a obtenção das espécies 3SRu foi o mesmo empregado na preparação da 4SRu, durante o mestrado [73]. Ou seja, inicialmente uma solução de $\left[\mathrm{Ru}(\text { bipy })_{2} \mathrm{Cl}_{2}\right.$ ] numa mistura etanol/água $1: 1$ foi aquecida $\left(\mathrm{T}=50^{\circ} \mathrm{C}\right)$ na presença de um equivalente de $\mathrm{AgNO}_{3}$. Este procedimento (figura 25) leva a formação do complexo $\left[\mathrm{Ru}(\text { bipy })_{2} \mathrm{Cl}\left(\mathrm{H}_{2} \mathrm{O}\right)\right]^{+}$e a precipitação de $\mathrm{AgCl}$ que foi removido por filtração em funil de placa sinterizada, recoberto com uma camada de aproximadamente $1 \mathrm{~cm}$ de celite. $A$ reação tem rendimento elevado, de modo que o filtrado essencialmente contém o complexo $\left[\mathrm{Ru}(\text { bipy })_{2} \mathrm{Cl}\left(\mathrm{H}_{2} \mathrm{O}\right)\right]^{+}$. Após a redução do volume para aproximadamente $5 \mathrm{~mL}$ no evaporador rotatório, foram adicionados à solução marrom escura $5 \mathrm{~mL}$ de diclorometano e a quantidade adequada de porfirina (garantindo um pequeno excesso de $1 \%$ do aqua complexo). Após 


\subsection{3 - Síntese e purificação das meso-(piridil)fenilporfirinas rutenadas}

cerca de 15 minutos de agitação e refluxo, o diclorometano foi removido no evaporador rotatório e a solução foi então gotejado sobre uma solução aquosa concentrada de $\mathrm{NaPF}_{6}$ ou LiTFMS (trifluorometanossulfonato de lítio) e filtrada num funil de placa sinterizada recoberta com uma camada de $1 \mathrm{~cm}$ de celite. $O$ funil foi lavado com água a fim de remover a fração de $\left[\mathrm{Ru}(\text { bipy })_{2} \mathrm{Cl}\left(\mathrm{H}_{2} \mathrm{O}\right)\right]^{+}$que não reagiu e o excesso de LiTFMS. Um sólido marrom escuro foi obtido após lavagem do funil com acetonitrila, e remoção do solvente no evaporador rotatório. Esse tipo de procedimento remove a maior parte dos reagentes de partida. Todavia faz-se necessário uma purificação mais rigorosa por cromatografia em coluna de alumina neutra, utilizando uma mistura diclorometano/etanol como eluente.

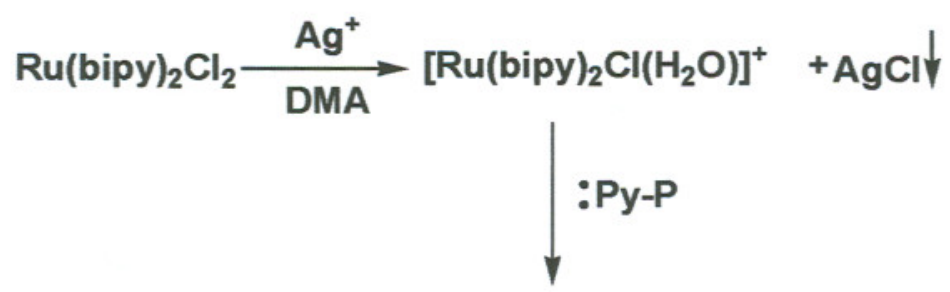

$\left[\mathrm{Ru}(\text { bipy })_{2} \mathrm{CIPy}\right]^{+} \mathrm{P}$

Figura 26: Esquema mostrando a rota sintética para a coordenação dos complexos de rutênio aos substituintes piridil das porfirinas $3 \mathrm{~S}$ e $4 \mathrm{~S}$.

Os complexos $\left[\mathrm{Ru}(\text { bipy })_{2} \mathrm{Cl}\left(\mathrm{H}_{2} \mathrm{O}\right)\right]^{+}$e $\left[\mathrm{Ru}(\text { bipy })_{2} \mathrm{Cl}_{2}\right]$ de partida, respectivamente, foram as duas primeiras frações removidas da coluna utilizando-se uma mistura de diclorometano (98\%) e etanol $(2 \%)$ com fase móvel. Em seguida, a polaridade do eluente foi aumentada com a adição de mais etanol ( $5 \%)$ removendo-se assim uma terceira fração correspondente à porfirina rutenada. O produto obtido é solúvel em solventes polares como etanol, metanol, DMF e acetonitrila. O rendimento da reação é de cerca de $95 \%$, quando o complexo de rutênio foi adicionado em pequeno excesso.

A coordenação das porfirinas aos complexos $\left[\mathrm{Ru}(\text { bipy })_{2} \mathrm{Cl}\left(\mathrm{H}_{2} \mathrm{O}\right)\right]^{+}$pode levar a formação de vários diasteroisômeros. Porém não foi possivel distinguí- 
6.1.3 - Síntese e purificação das meso-(piridil)fenilporfirinas rutenadas

los por meio dos estudos de suas propriedades espectroscópicas, eletroquímicas e fotofísicas, comportando-se como se fossem substâncias puras.

A coordenação das $3 \mathrm{~S}$ e $4 \mathrm{~S}$ aos complexos $\left[\mathrm{Ru}(\text { bipy })_{2} \mathrm{Cl}\left(\mathrm{H}_{2} \mathrm{O}\right)\right]^{+}$causou uma diferenciação bastante significativas entre os espectros eletrônicos (figura 27) de ambas as séries de compostos. A 3SRu, por exemplo, apresentou uma banda Soret com maior absortividade molar, além de ter uma largura de banda menor em relação à espécie correspondente 4SRu. Isto pode sugerir um menor acoplamento do anel porfirinico com os complexos periféricos quando este se encontra ligado através da posição meta do residuo piridil.

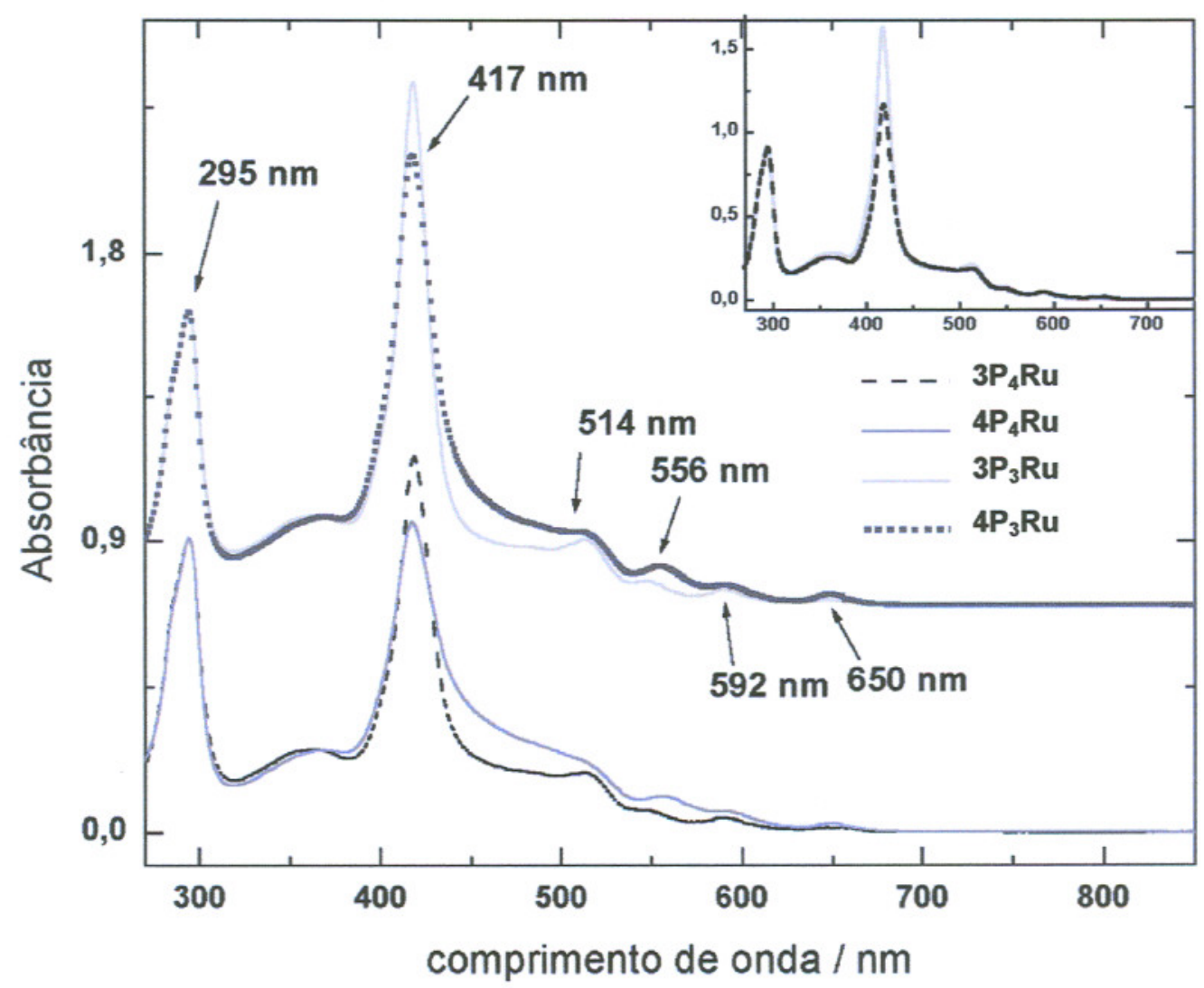

Figura 27: Espectros UV-Vis comparativo entre as espécies $3 P_{3} R u, 4 P_{3} R u$, $3 \mathrm{P}_{4} \mathrm{Ru}$ e $4 \mathrm{P}_{4} \mathrm{Ru}$, em DMF. 
As diferenças estruturais das séries 3SRu e 4SRu devem aparecer também nos espectros de ${ }^{1} \mathrm{H}$ RMN. De fato, o número de sinais é muito maior no caso dos isômeros 3SRu de menor simetria, levando ao aparecimento de envelopes de sinais. Consequentemente, a simples mudança da disposição dos complexos de rutênio para fora do plano do anel porfirínico, tornou os espectros de ${ }^{1} \mathrm{H}$ RMN praticamente impossiveis de serem interpretados de maneira mais minuciosa. Nestes casos, apenas o número integrado de prótons pode ser determinado, e foram consistentes com a estruturas correspondentes. Assim, a caracterização estrutural daquelas porfirinas supramoleculares foi realizada utilizando técnicas como voltametria ciclica e voltamograma de pulso diferencial, que permite entre outras coisas, determinar 0 número de complexos de rutênio coordenados às meso-(piridil)fenilporfirinas.

As porfirinas da série $3 S R u$ apresentaram voltamogramas cíclicos (figura 28) semelhantes aos dos seus isômeros em para [73]. Por exemplo, é possivel observar processos monoeletrônicos reversiveis para a oxidação dos complexos de rutênio $\left(\mathrm{Ru}^{3+/ 2+}\right)$ e a primeira redução do anel porfirínico $\left(\mathrm{P}^{\mathrm{O} / \mathrm{r}}\right)$. A razão da intensidade do primeiro pelo segundo processo expressa a razão entre o número de grupos $\left[\mathrm{Ru}(\text { bipy })_{2} \mathrm{Cl}\right]^{+}$em relação a de porfirina. Neste caso, foram obtidos valores de 1, 2, 2, 3 e 4 para os complexos $3 \mathrm{PRu}, 3 \mathrm{P}_{2 t} \mathrm{Ru}, 3 \mathrm{P}_{2 c} \mathrm{Ru}, 3 \mathrm{P}_{3} \mathrm{Ru}$ e $3 \mathrm{P}_{4} \mathrm{Ru}$, mostrando que as espécies contém o número adequado de complexos de $\left[\mathrm{Ru}(\text { bipy })_{2} \mathrm{Cl}\right]^{+}$coordenados. Este aspecto pode ser melhor observado comparando as intensidades daquelas ondas nos voltamogramas de pulso diferencial mostrados na figura 28. Além disso, podem ser observados ondas quasi-reversiveis e irreversiveis que foram atribuidas à primeira oxidação $\left(\mathrm{P}^{+/ 0}\right)$ e à segunda redução $\left(\mathrm{P}^{-/ 2}\right)$ do anel porfirínico e às reduções monoeletrônicas de cada um dos ligantes bipiridina dos complexos periféricos (bipy ${ }^{0 /-}$ e bipy ${ }^{-12-}$ ). 
6.1.3 - Síntese e purificação das meso-(piridil)fenilporfirinas rutenadas

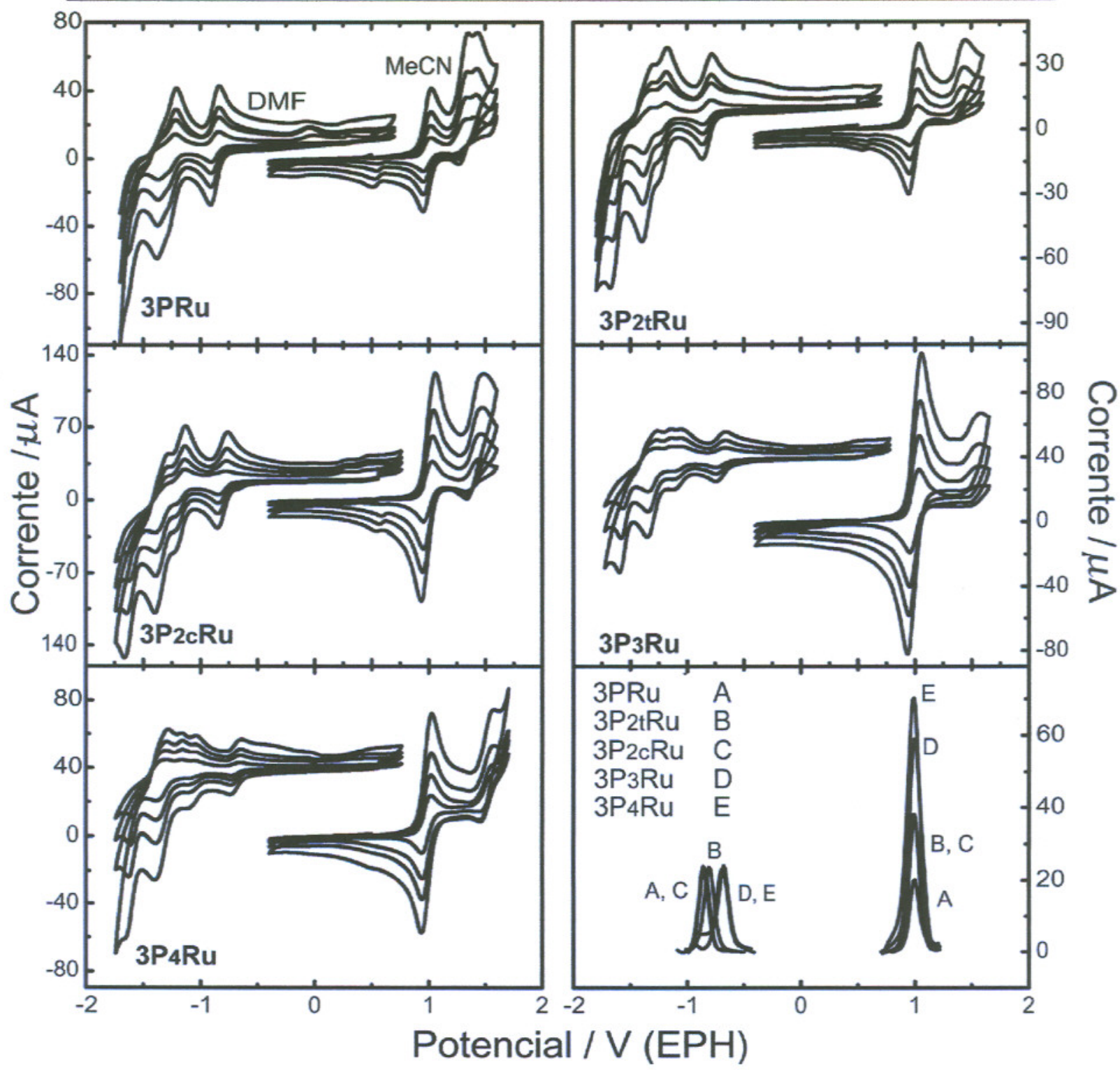

Figura 28: Voltamogramas ciclicos e voltamogramas de pulso diferencial (DPV, à direita, em baixo) das meso-(3-piridil)fenilporfirinas rutenadas em MeCN (acima de 0,00 V) e em DMF (abaixo de 0,00 V).

De um modo geral, a série 3SRu apresenta valores de potenciais redox

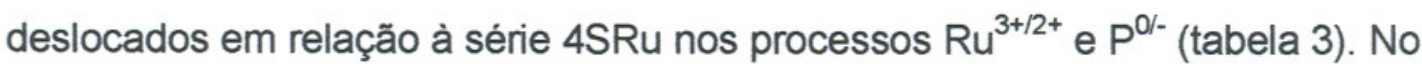
primeiro a diferença é de aproximadamente $100 \mathrm{mV}$ superior enquanto que para o segundo, cerca de $50 \mathrm{mV}$ a menos. 
6.1.3 - Síntese e purificação das meso-(piridil)fenilporfirinas rutenadas

Tabela 3: Potenciais redox para os isômeros meta e para rutenados em solução de acetonitrila (acima de 0,00 V) e em DMF (abaixo de 0,00 V). $a=$ potencial de pico anódico, $c=$ potencial de pico catódico.

\begin{tabular}{|c|c|c|c|c|c|c|}
\hline & $\mathrm{Ru}^{3+12+}$ & $\mathrm{P}^{+/ 0}$ & $P^{0 /-}$ & $P^{-12-}$ & bipy ${ }^{0 /-}$ & bipy $^{-12-}$ \\
\hline 3PRu & 0,99 & $1,34^{a}$ & $-0,86$ & $-1,23$ & $-1,36^{c}$ & $-1,59^{c}$ \\
\hline $3 P_{2 t} R u$ & 0,99 & $1,45^{a}$ & $-0,80$ & $-1,19$ & $-1,38^{c}$ & $-1,64^{\mathrm{C}}$ \\
\hline $3 P_{2 c} R u$ & 0,99 & $1,48^{\mathrm{a}}$ & $-0,84$ & $-1,16$ & $-1,40^{c}$ & $-1,65^{\mathrm{C}}$ \\
\hline $3 P_{3} R u$ & 1,00 & $1,58^{\mathrm{a}}$ & $-0,70$ & $-1,08^{c}$ & $-1,35^{c}$ & $-1,60^{c}$ \\
\hline $3 P_{4} R u$ & 0,99 & $1,57^{a}$ & $-0,68$ & $-1,06^{c}$ & $-1,39^{c}$ & $-1,63^{c}$ \\
\hline 4PRu & 0,89 & $1,26^{a}$ & $-0,90$ & $-1,22$ & $-1,56^{\mathrm{C}}$ & - \\
\hline $4 P_{2 t} R u$ & 0,89 & $1,42^{a}$ & $-0,84$ & $-1,14$ & $-1,43$ & - \\
\hline $4 P_{2 c} R u$ & 0,90 & $1,43^{a}$ & $-0,86$ & $-1,19$ & $-1,39$ & - \\
\hline $4 P_{3} R u$ & 0,90 & $1,4^{a}$ & $-0,76$ & $-1,02^{c}$ & $-1,39^{c}$ & - \\
\hline $4 \mathrm{P}_{4} \mathrm{Ru}$ & 0,96 & $1,6^{a}$ & $-0,68$ & $-0,93$ & $-1,42^{\mathrm{C}}$ & - \\
\hline
\end{tabular}

Para a realização de testes em água ou em tampão, todas as 10 espécies rutenadas tiveram seus contra-ions trocados por $\mathrm{Cl}^{-}$por meio da adição gota a gota das respectivas soluções concentradas, em DMF, em soluções saturadas de $\mathrm{LiCl}$ em acetona. $\mathrm{O}$ precipitado foi filtrado e lavado algumas vezes com acetona e depois sêco sob vácuo. 


\subsubsection{RENDIMENTO QUÂNTICO DE FORMAÇÃO DE ${ }^{1} \mathrm{O}_{2}-\phi_{\Delta}$}

As eficiências na formação de ${ }^{1} \mathrm{O}_{2}$, em $\mathrm{D}_{2} \mathrm{O}$, para as duas espécies tetracatiônicas, $3 \mathrm{P}_{4} \mathrm{Me}$ e $4 \mathrm{P}_{4} \mathrm{Me}$ (figura 29), foram muito semelhantes e mantiveram-se relativamente constantes para as demais espécies da $3 S$ metilada (3SMe). Todavia, para os correspondentes isômeros da 4S (4SMe), foi obtido uma diminuição bastante significativa dos valores rendimentos quânticos em função da diminuição do número de grupos $\mathrm{N}$-metilpiridinio catiônicos. De fato, foi observada uma diminuição linear em função do número de cargas positivas dos sensibilizadores porfirinicos catiônicos, como mostrado na figura 29 e tabela 4.

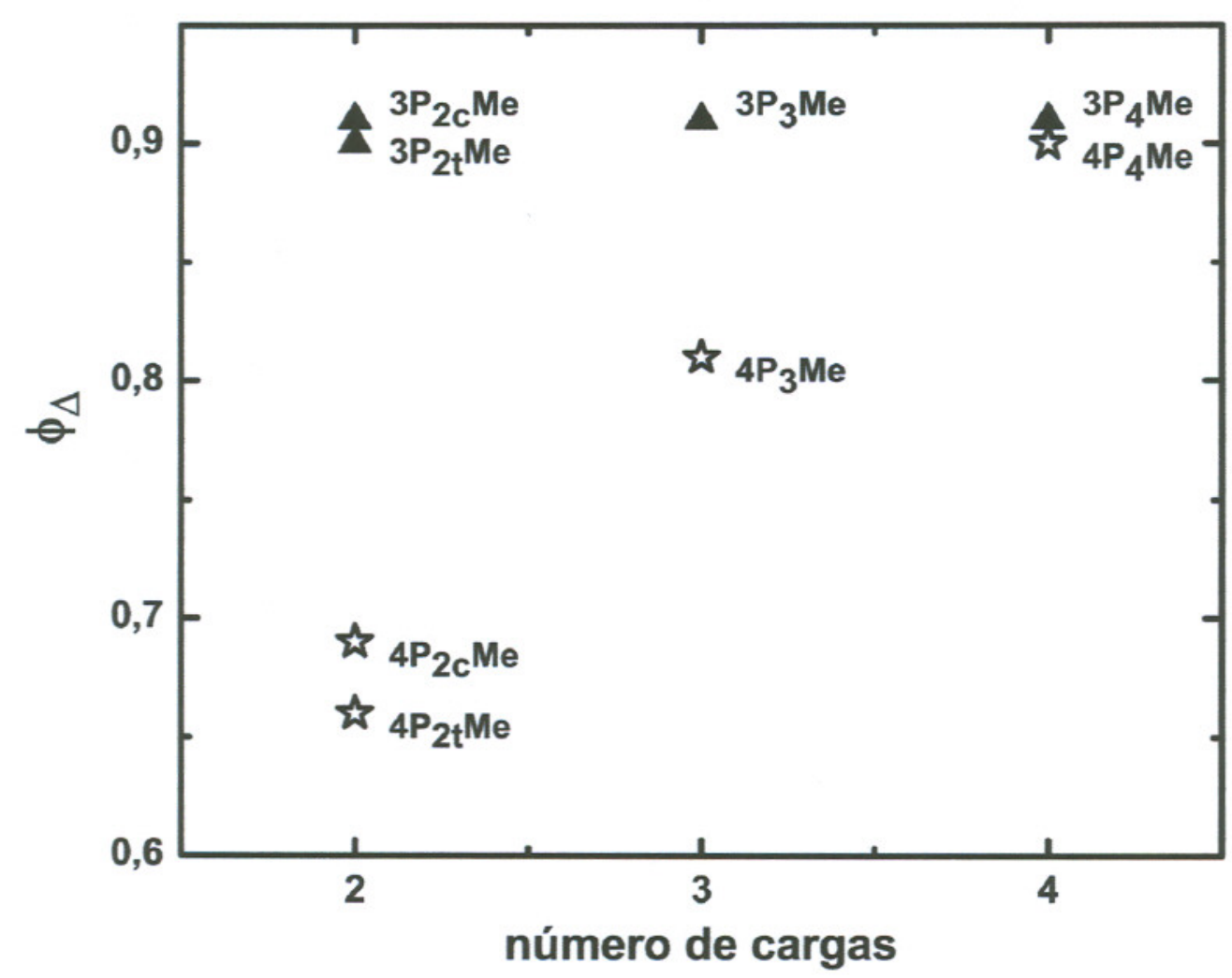

Figura 29: Gráfico dos rendimentos quânticos de formação de ${ }^{1} \mathrm{O}_{2}\left(\phi_{\Delta}\right)$ (em $\mathrm{D}_{2} \mathrm{O}$ ) em função do número de grupos $\mathrm{N}$-metilpiridínio das espécies das séries $3 \mathrm{SMe}(\boldsymbol{\Delta})$ e $4 \mathrm{SMe}(\hat{\mathfrak{s}})$. Os pontos representam a média de quatro medidas, sendo o desvio inferior $a \pm 0,05$. 
Tabela 4: Rendimento quântico de formação de ${ }^{1} \mathrm{O}_{2}\left(\phi_{\Delta} \pm 0,05\right)$ determinados em $\mathrm{D}_{2} \mathrm{O}$, utilizando-se $4 \mathrm{P}_{4} \mathrm{Me}$ como padrão. As concentrações de porfirina foram controladas de modo que a absorção em $532 \mathrm{~nm}$ fosse igual a 0,3 UA ( 0,2 mM de porfirina). Os dados representam a média de quatro medidas, sendo o desvio médio inferior $a \pm 0,05$.

\begin{tabular}{|c|c|}
\hline & $\phi_{\Delta}\left(D_{2} \mathrm{O}\right)$ \\
\hline $3 \mathrm{P}_{2 \mathrm{c}} \mathrm{Me}$ & 0,91 \\
\hline $3 \mathrm{P}_{2 \mathrm{t}} \mathrm{Me}$ & 0,86 \\
\hline $3 \mathrm{P}_{3} \mathrm{Me}$ & 0,91 \\
\hline $3 \mathrm{P}_{4} \mathrm{Me}$ & 0,89 \\
\hline $4 \mathrm{P}_{2 \mathrm{c}} \mathrm{Me}$ & 0,64 \\
\hline $4 \mathrm{P}_{2 \mathrm{t}} \mathrm{Me}$ & 0,61 \\
\hline $4 \mathrm{P}_{3} \mathrm{Me}$ & 0,72 \\
\hline $4 \mathrm{P}_{4} \mathrm{Me}$ & 0,90 \\
\hline
\end{tabular}

Jori e colaboradores [32] observaram um comportamento similar para a 4SMe com uma concentração de porfirina 24 vezes menor, em solução tampão PBS. Porém, na presença de SDS $(70 \mathrm{mM})$ ou CTAB $(10 \mathrm{mM})$, foi observado uma tendência de diminuição da diferença entre os valores de $\phi_{\Delta}$ na série.

Este comportamento mostra um perfil que não pode ser explicado de maneira simples, baseando-se apenas na estrutura dos compostos. A princípio, espera-se que o aumento do número de grupos $\mathrm{N}$-metilpiridinio leve a uma diminuição do rendimento quântico e não a um aumento. Isto se deve ao fato daqueles sitios possuírem cargas e aumentarem as interações do tipo dipolo-dipolo com o solvente $\left(\mathrm{D}_{2} \mathrm{O}\right)$, que podem favorecer a desativação térmica das espécies no estado excitado [73]. Esta hipótese é em parte confirmada pelos resultados obtidos para a $3 S \mathrm{Me}$, onde $\phi_{\Delta}$ se mantém constante em função independentemente do número de grupos $N$ metilpiridinio. Assim, pode-se verificar que a contribuição desses grupos no processo de decaimento não radiativo das espécies no estado excitado é insignificante no caso das porfirinas catiônicas em questão. Por outro lado, uma mudança na conformação dos grupos $N$-metilpiridinio periféricos de meta 
6.1.4 - Rendimento Quântico de Formação de ${ }^{1} \mathrm{O}_{2}-\phi_{\Delta}$

para para não deve influenciar tão drasticamente o comportamento fotofísico, apesar do maior acoplamento eletrônicos desses grupos com 0 anel porfirínico [84]. Assim, existem fortes evidências de que processos de associação em solução, formando dimeros e eventualmente oligômeros superiores, estão relacionados com o decréscimo do rendimento quântico de formação de oxigênio singlete em função da diminuição do número de cargas positivas na série $4 \mathrm{SMe}$. Este comportamento reflete a estrutura planar da molécula, que favorece uma maior interação entre as nuvens $\pi$ das moléculas de porfirina.

A presença daqueles agregados influencia sensivelmente os processos fotoquimicos e fotofísicos, causando uma rápida desativação das espécies no estado excitado por processos de relaxação térmica. Assim, a presença de dimeros e oligômeros superiores provoca a diminuição do tempo de vida e conseqüentemente da eficiência dos processos radiativos e de transferência de energia, $\phi_{\text {ffl }}, \phi_{\text {cis }}$ e $\phi_{\Delta}$. Esses processos de agregação não foram observados para as porfirinas da série $3 \mathrm{SMe}$, mesmo em concentrações de 0,5 mM.

Este comportamento parece sugerir que a disposição espacial dos sítios eletricamente carregadas em torno do anel porfirínico influencia fortemente as interações intermoleculares. Isto pode ser visualizado comparando-se os valores de $\phi_{\Delta}$ para os isômeros dicatiônicos, cis e trans. Em ambas as séries (figura 29), o isômero cis apresenta maior eficiência de formação de ${ }^{1} \mathrm{O}_{2}$. Neste caso, a disposição assimétrica das duas cargas, voltadas para um dos lados da molécula, aumenta a polaridade daquela molécula em relação ao isômero onde aqueles grupos se situam simetricamente em lados opostos, atribuindo um caráter anfipático àquela espécie.

Pode-se notar pela discussão acima que a estrutura das moléculas influencia fortemente as interações entre as mesmas e, conseqüentemente com outras moléculas. Logo, devem definir os sítios e o modo de interação dos sensibilizadores porfirinicos catiônicos com as biomoléculas, que por sua vez 
6.1.5 - Coeficiente de Partição n-octanol/água (LogP $P_{\text {AA }}$

deve influenciar fortemente a eficiência das mesmas como sensibilizadores. Aquele comportamento pode ser previsto utilizando-se como parâmetro oscoeficientes de partição n-octanol/água das mesmas, discutido na próxima seção.

\subsubsection{COEFICIENTE DE PARTIÇÃO n-OCTANOLÁGUA (logPOA)}

A literatura contendo valores de coeficiente de partição, utilizando o sistema convencional $n$-octanol/água, é bastante vasta. Todavia, informação referentes ao $\log \mathrm{P}_{\mathrm{OA}}$ de porfirinas e seus derivados são relativamente raras. $\mathrm{A}$ $4 \mathrm{P}_{4} \mathrm{Me}$ é uma das porfirinas mais comumente utilizadas, porém os valores de partição reportados por Meng [71], kepczynski [85] e Ricchelli [31] apresentaram-se bastante discrepância, -0,35, -2,24 e -2,75, respectivamente.

Semelhantemente, os nossos resultados iniciais de $\log \mathrm{P}_{\mathrm{OA}}$, realizados segundo o mesmo procedimento descrito por aqueles autores, mostraram uma baixa reprodutibilidade entre as medidas, apresentando valores aleatórios. $\mathrm{Na}$ verdade, monitorando-se a absorção da banda Soret para $4 \mathrm{P}_{4} \mathrm{Me}$ ou $4 \mathrm{P}_{3} \mathrm{Me}$ na fase aquosa, observava-se de fato uma diminuição da concentração das amostras após a agitação. Todavia, a análise do espectro eletrônico da fase orgânica demonstrou ausência completa das bandas da porfirina. Curiosamente, ao remover todo o conteúdo do frasco onde foi realizado o experimento de partição e adicionar uma solução aquosa ácida $(\mathrm{pH} \sim 1)$, observou-se uma coloração verde intensa característica da protonação do anel porfirínico. Estes resultados sugerem um forte efeito de adsorção das amostras nas paredes do recipiente.

O experimento foi novamente repetido, porém agora, após a agitação e centrifugação, a fase orgânica foi completamente removida do recipiente. $\grave{A}$ solução aquosa restante foi então acidificada com alguns $10 \mu \mathrm{L}$ de $\mathrm{HCl}$ concentrado e as absorções, com a solução inicial também acidificada, foram comparadas. 
6.1.5 - Coeficiente de Partição n-octanol/água (LogP $P_{O A}$

Neste caso, não foram observados variações significativas, evidenciando claramente que as diferenças de absorbância das porfirinas na fase aquosa foram devido à adsorção e não à partição. Infelizmente, este inconveniente processo se torna ainda mais crítico à medida que a porfirina se torna menos hidrofílica (diminui o número de grupos metilpiridinio). Este comportamento pode explicar a diferença dos valores encontrados na literatura.

Para a determinação do processo de partição é fundamentalmente necessário que a amostra seja minimamente solúvel em ambos os solventes. Descobriu-se, posteriormente, que este pré-requisito somente era atendido quando o n-octanol estava seco. A umidificação, durante o processo de présaturação com água, demonstrou provocar uma diminuição bastante pronunciada da solubilidade das porfirinas neste solvente. Este efeito pode ser um dos responsáveis pela baixa reprodutibilidade e inconsistência dos dados de coeficiente de partição.

Uma estratégia alternativa para contornar o problema foi a substituição do n-octanol por um solvente que mantivesse as mesmas propriedades de transparência no visivel e imiscibilidade em água, porém com um menor caráter hidrofóbico. Um alcool alifático de cadeia menor, como o $n$ butanol $(\mathrm{BuOH})$, mostrou-se adequado e apresentou resultados consistentes e reprodutiveis, acompanhando-se a concentração das amostras na fase orgânica e na fase aquosa.

Seiler [86] e El Tayar [87] mostraram a existência de uma relação linear entre os coeficientes de partição em n-octanol e diferentes solventes do tipo: $\log \mathrm{P}_{\mathrm{OA}}=\mathrm{a} \cdot \log \mathrm{P}_{\text {solvente }}+\mathrm{b}$.

Desta forma foi necessário construir uma curva de correlação relacionando os resultados entre estes dois solventes. Para isto, utilizou-se de compostos padrões com coeficientes de partição bem definidos em $\mathrm{OcOH}$ (figura 30 à cima ; tabela 5). Os padrões [88] foram selecionados de modo que os valores de logP $\mathrm{PA}_{\mathrm{A}}$ abrangessem tanto valores negativos quanto positivos e apresentassem bandas intensas de absorção na região de 250 a $900 \mathrm{~nm}$, para serem detectadas pelo mesmo método (espectrofotométrico). 
6.1.5 - Coeficiente de Partição n-octanollágua (LogP $\left.P_{O A}\right)$

Apesar das tendências serem similares, os resultados de log $\mathrm{P}_{\mathrm{OA}}$ obtidos por este novo método são até 3 ordens de grandeza diferentes daqueles encontrados anteriormente.

Pode-se notar uma nítida distinção entre as séries 3-piridil e 4piridilporfirinas com grupos metila e $\left[\mathrm{Ru}(\text { bipy })_{2} \mathrm{Cl}\right]^{+}$ligadas aos átomos de nitrogênio piridínicos, como mostrado na figura 30 (à baixo). É interessante notar que esta diferença torna-se menor a medida que diminui-se o número de grupos positivamente carrregados, convergindo para um valor em comum para todas as amostras. Isto sugere que, no caso das porfirinas com um único substituinte positivamente carregado, pequenas variações de posição ou da natureza daqueles grupos periféricos não influenciam significativamente os coeficientes de partição. Provavelmente isto seja devido à predominância do elevado efeito hidrofóbico referente ao restante da molécula de porfirina.

A obtenção de valores de logP $\mathrm{OA}_{\mathrm{A}}$ mais negativos para a $3 \mathrm{SMe}$ em relação a $4 \mathrm{SMe}$, indicam que a primeira série é mais hidrofilica e que está menos sujeita a efeitos de associação que a $4 \mathrm{SMe}$. O mesmo paralelo pode ser realizado entre os isômeros dicatiônicos, cis e trans, onde a estrutura anfipática do primeiro mostrou menor agregação. Estes resultados corroboram o perfil observado nos valores de $\phi_{\Delta}$ e este comportamento deve ser ainda mais pronunciado em concentrações mais elevadas do fotossensibilizador. 
6.1.5 - Coeficiente de Partição n-octanol/água ( $\left.\log P_{O A}\right)$
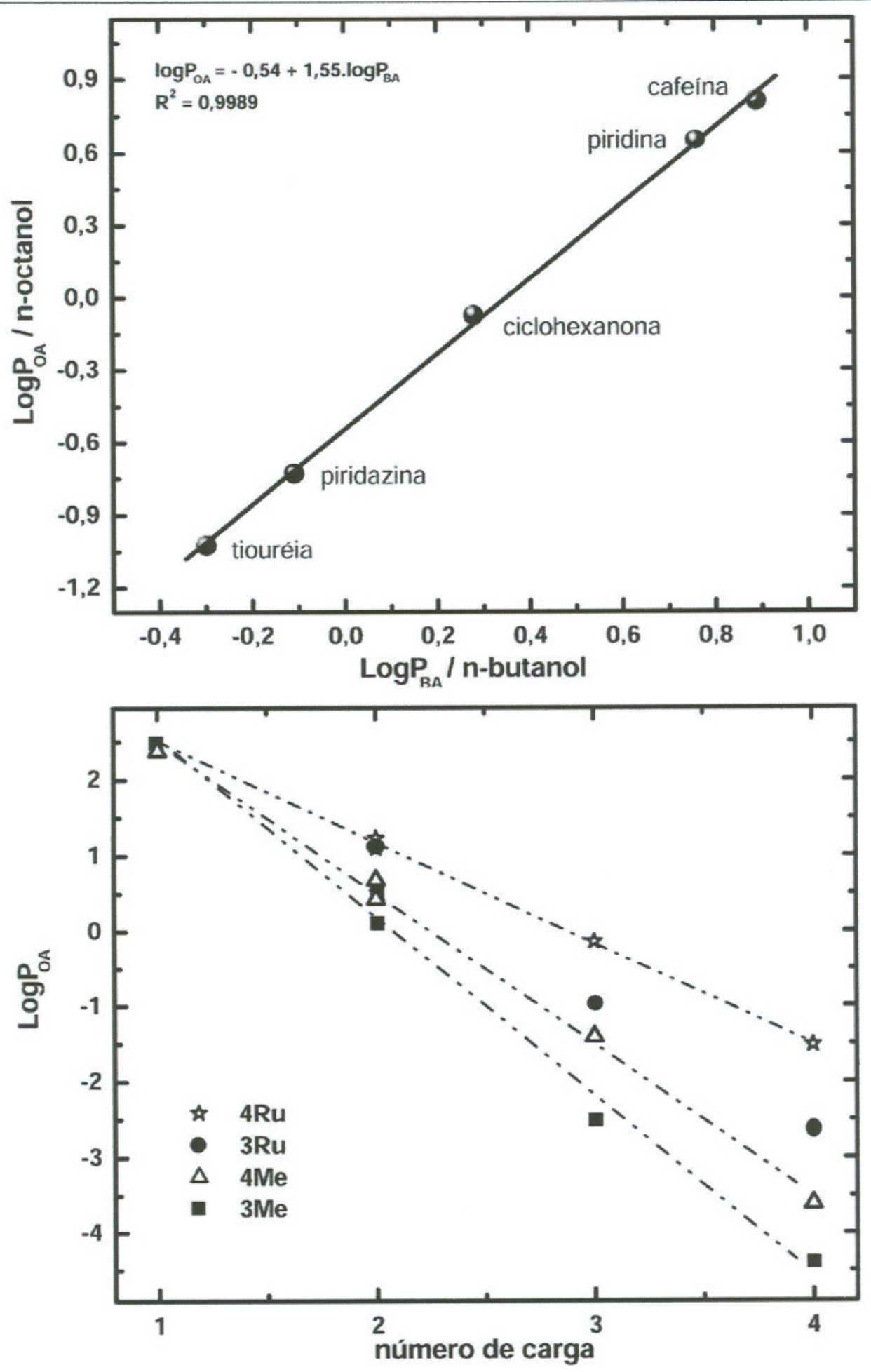

Figura 30: $\grave{A}$ esquerda, gráfico mostrando a relação dos coeficientes de partição em n-octanol/água (log $\left.\mathrm{P}_{\mathrm{OA}}\right)$ e $n$-butanol/água $\left(\log \mathrm{P}_{\mathrm{BA}}\right)$ para compostos padrões. À direita, gráfico relacionando o número de cargas das porfirinas metiladas e rutenadas com o log $\mathrm{P}_{\mathrm{OA}}$ experimental. 
6.1.5 - Coeficiente de Partição n-octanol/água (LogP $\left.P_{O A}\right)$

A coordenação dos complexos de rutênio à porfirina mostrou aumentar mais acentudamente a partição do composto em meio orgânico em relação as espécies metiladas de mesma carga e posição de ligação à piridina. Esta hidrofobicidade é provavelmente atribuida a presença de duas moléculas de bipiridinas, em cada átomo de rutênio.

Tabela 5: Relação dos coeficientes de partição em n-octanol/água (logP $O A$ ) e $n$-butanol/água $\left(\log \mathrm{P}_{\mathrm{BA}}\right)$ para as porfirinas metiladas $(\mathrm{Me})$ e rutenadas $(\mathrm{Ru}) \mathrm{e}$ os valores calculados (negrito itálico) para as $35 \mathrm{Me}$ e $4 \mathrm{SMe}$ utilizando o programa Pallas 3.1 .

\begin{tabular}{|c|c|c|c|c|c|}
\hline & \multicolumn{2}{|c|}{$\log P_{B A}$} & \multicolumn{2}{|c|}{$\log P_{O A}$} & \multirow{2}{*}{$\frac{\log P_{O A}}{M e}$} \\
\hline & $\mathrm{Me}$ & $\mathbf{R u}$ & $\mathrm{Me}$ & $\mathbf{R u}$ & \\
\hline $3 P$ & 1,95 & - & 2,49 & - & 7,31 \\
\hline $3 P_{2 t}$ & 0,69 & - & 0,53 & - & 3.31 \\
\hline $3 P_{2 c}$ & 0,42 & 1,08 & 0,11 & 1.13 & 3.31 \\
\hline $3 P_{3}$ & $-1,27$ & $-0,28$ & $-2,52$ & $-0,98$ & $-0,68$ \\
\hline $3 P_{4}$ & $-2,49$ & $-1,34$ & $-4,41$ & $-2,63$ & $-4,68$ \\
\hline $4 P$ & 1,88 & - & 2,38 & - & 7,31 \\
\hline $4 \mathrm{P}_{2 t}$ & 0,79 & 1,14 & 0,68 & 1,23 & 3,31 \\
\hline $4 P_{2 c}$ & 0,63 & 1,06 & 0,43 & 1,10 & 3,31 \\
\hline $4 P_{3}$ & $-0,56$ & 0,26 & $-1,41$ & $-0,14$ & $-0,68$ \\
\hline $4 P_{4}$ & $-1,97$ & $-0,63$ & $-3,61$ & $-1,52$ & $-4,68$ \\
\hline
\end{tabular}

\begin{tabular}{c|c|c|c}
\hline cafeina & 0,89 & 0,81 & \\
piridina & 0,76 & 0,65 & \\
ciclohexanona & 0,28 & $-0,07$ & \\
piridazina & $-0,11$ & $-0,73$ & \\
tiouréia & $-0,30$ & $-1,02$ & \\
\hline
\end{tabular}

Estes resultados são muito interessantes pois mostram que 0 posicionamento da carga positiva na posição meta do anel piridinico promove 
6.1.5 - Coeficiente de Partição n-octanol/água (LogP $\left.P_{O A}\right)$

um acréscimo de hidrofilicidade do composto em relação a posição para. Este efeito parece estar associado a possibilidade de disposição das cargas positivas para fora do plano do anel porfirínico (figura 31), através da livre rotação da piridina em torno da ligação meso, no caso dos isômeros meta. Este processo deve dificultar as interações $\pi$ responsáveis pela formação de dímeros ou oligômeros superiores.

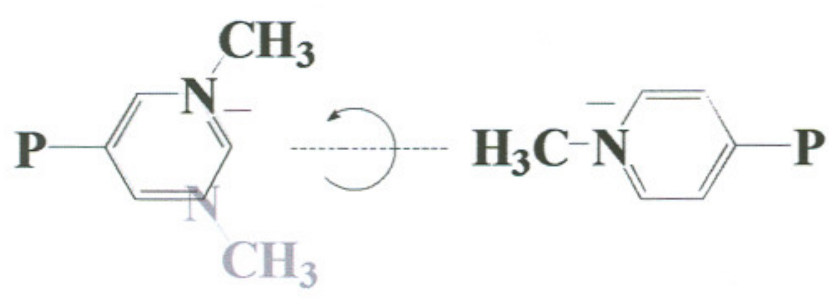

Figura 31: Esquema ilustrativo mostrando a disposição dos grupos metil-piridínio nos derivados meta e para e seus respectivos volume de rotação.

A modulação da partição em função da variação estrutural do fotossensibilizador, sem diminuição no $\phi_{\Delta}$, deve propiciar a observação de efeitos de ligação e de morte celular bastante distintos. A interação com células, sucedida de irradiação, pode auxiliar a compreensão de alguns dos mecanismos envolvidos nos processos fotodinâmicos. 


\subsubsection{HEMÓLISE DE ERITRÓCITOS}

A integridade da membrana celular de eritrócitos pode ser avaliada pela intensidade de luz espalhada por uma suspensão destas células. A diminuição do espalhamento é um reflexo da completa ruptura da estrutura celular gerando fragmentos de tamanho menores. Quando este processo é induzido por excitação de um fotossensibilizador, geralmente está associado ao ataque do ${ }^{1} \mathrm{O}_{2}$ gerado aos fosfolipídios insaturados presentes na membrana celular, formando hidroperóxidos [75,76]. Estas espécies instáveis rapidamente se desproporcionam gerando radicais livres que iniciam uma série de reações em cadeia, responsáveis pelo colapso da célula. Contudo, o oxigênio singlete é uma espécie muito reativa, reagindo rapidamente com as espécies presentes na vizinhança. Isto faz com que ele possa se difundir apenas dentro de um espaço bastante restrito. Assim, a eficiência do processo de hemólise fotoinduzido, na presença de um sensibilizador, pode ser utilizada para se estudar - grau de interação e penetração dos fotossensibilizadores na membrana celular, pois somente as moléculas de oxigênio singlete geradas na membrana ou muito próximo de sua superficie poderão provocar danos à mesma.

Experimentos cinéticos foram realizados monitorando-se a variação do espalhamento de luz provocado pelos eritrócitos intactos em função do tempo. Os espectros UV-Vis foram obtidos em intervalos de tempo constantes irradiando-se uma cubeta contendo uma suspensão de eritrócito e as porfirinas catiônicas com luz monocromática de $532 \mathrm{~nm}$ e $20 \mathrm{~mW}$ de potência. Em todos os casos foi observado um período de indução no qual o espalhamento se mantém constante, seguido de um declinio relativamente rápido do espalhamento até atingir a linha base em $650 \mathrm{~nm}$ (figura 32). Este comprimento de onda foi selecionado para realizar os estudos cinéticos pois não existem bandas de absorção da hemoglobina nessa região, possibilitando acompanhar apenas a variação de espalhamento. 


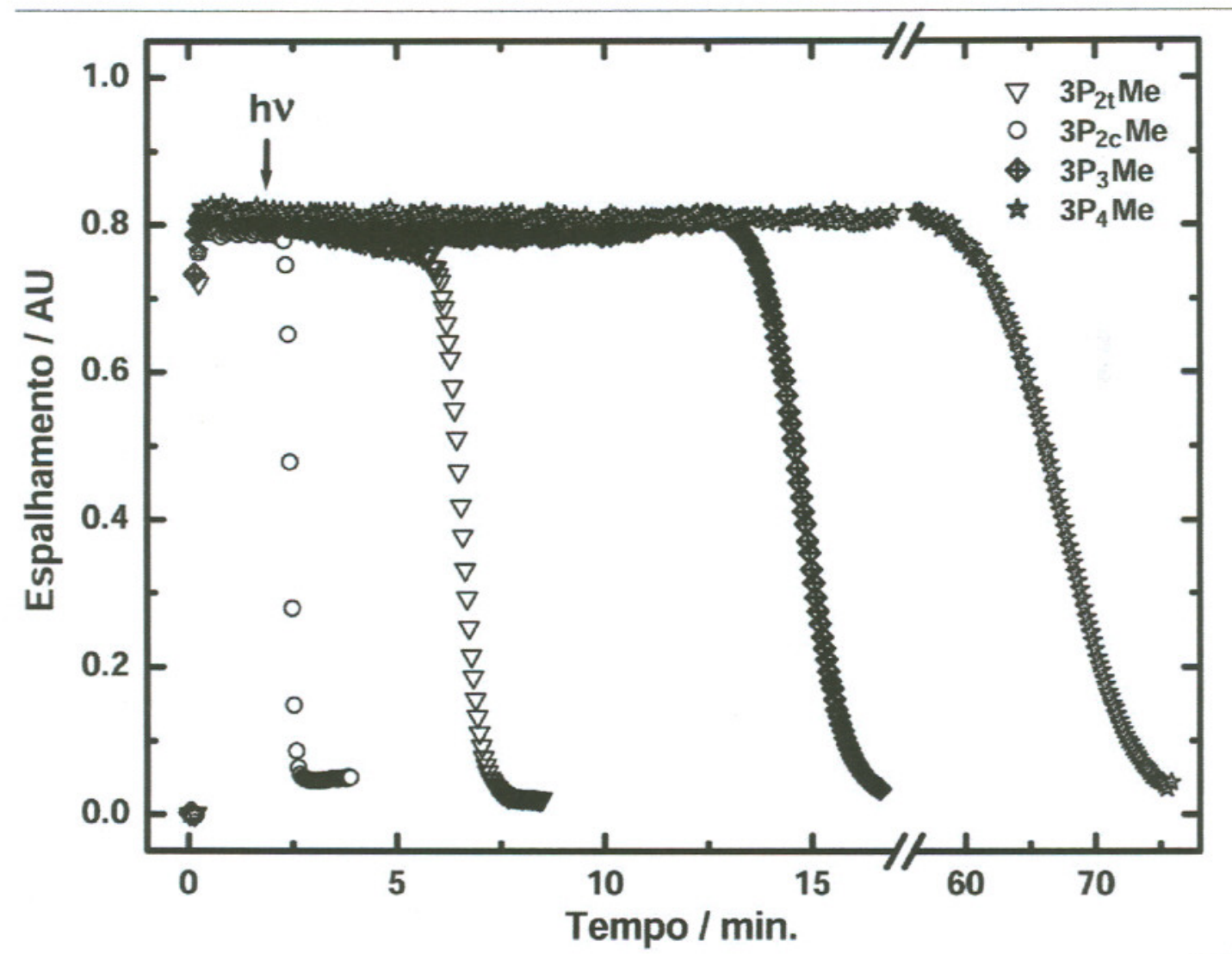

Figura 32: Variação da intensidade de espalhamento $(e m 650 \mathrm{~nm})$ de soluções de 3-piridil porfirinas metiladas ( 1,0 AU em $417 \mathrm{~nm}$ ), em solução salina de tampão fosfato (PBS), após a adição de um volume definido de uma suspensão de eritrócitos e irradiação continua com luz monocromática de $532 \mathrm{~nm}(20 \mathrm{~mW})$. A seta indica o início da irradiação.

Nota-se claramente que o tempo de indução e a velocidade de declinio do espalhamento, ou seja, velocidade de destruição da membrana celular dos eritrócitos, é dependente da porfirina catiônica empregada como sensibilizador. Concomitantemente com o extravasamento da hemoglobina para a solução, ocorre o aumento da banda Soret em $420 \mathrm{~nm}$.

O tempo de indução provavelmente está relacionado com o consumo dos anti-oxidantes presentes na membrana celular, tais como tocoferóis (vitamina E) e carotenóides $[18,19]$. Como estes são muito mais reativos que 


\subsection{6 - Hemólise de eritrócitos}

os fosfolipideos que constituem a membrana, esta não pode ser atacada enquanto aqueles redutores não forem consumidos. Além disso, a membrana celular é um sistema complexo com certo poder de auto-reparação. Assim, sua "destruição" depende da ocorrência de uma concentração limite de sítios danificados. Logo, o tempo de indução está relacionado com a eficiência de geração de oxigênio singlete na membrana celular pelos sensibilizadores, que deve ser fortemente dependente da interação entre as mesmas. Por outro lado, pode-se perceber pelas curvas que a velocidade de hemólise é rápida, provavelmente envolvendo reações radicalares em cadeia. Assim, quando a concentração de radicais na membrana atingir um certo valor limite, ocorreria a perfuração e o extravazamento do conteúdo dos eritrócitos. Assim, considerando-se apenas a região em que se observa a diminuição do espalhamento, a velocidade de hemólise fotoinduzida pode ser estimada pelo coeficiente angular da variação do espalhamento em função do tempo, nas condições experimentais utilizadas, ou seja, a derivada primeira das curvas da figura 32. Neste caso, a intensidade e posição dos máximos podem ser correlacionados com a velocidade de hemólise e o tempo de indução, respectivamente. Pode-se notar na figura 33 que estes dois parâmetros diminuem com o aumento do número de grupos $N$-metilpiridínio das porfirinas da $3 \mathrm{SMe}$, sendo que o isômero cis apresenta uma eficiência 7 vezes maior que o isômero trans e 90 vezes maior que a porfirina tetracationica. Este comportamento parece estar associado às propriedades de partição do fotossensibilizador na membrana celular. 


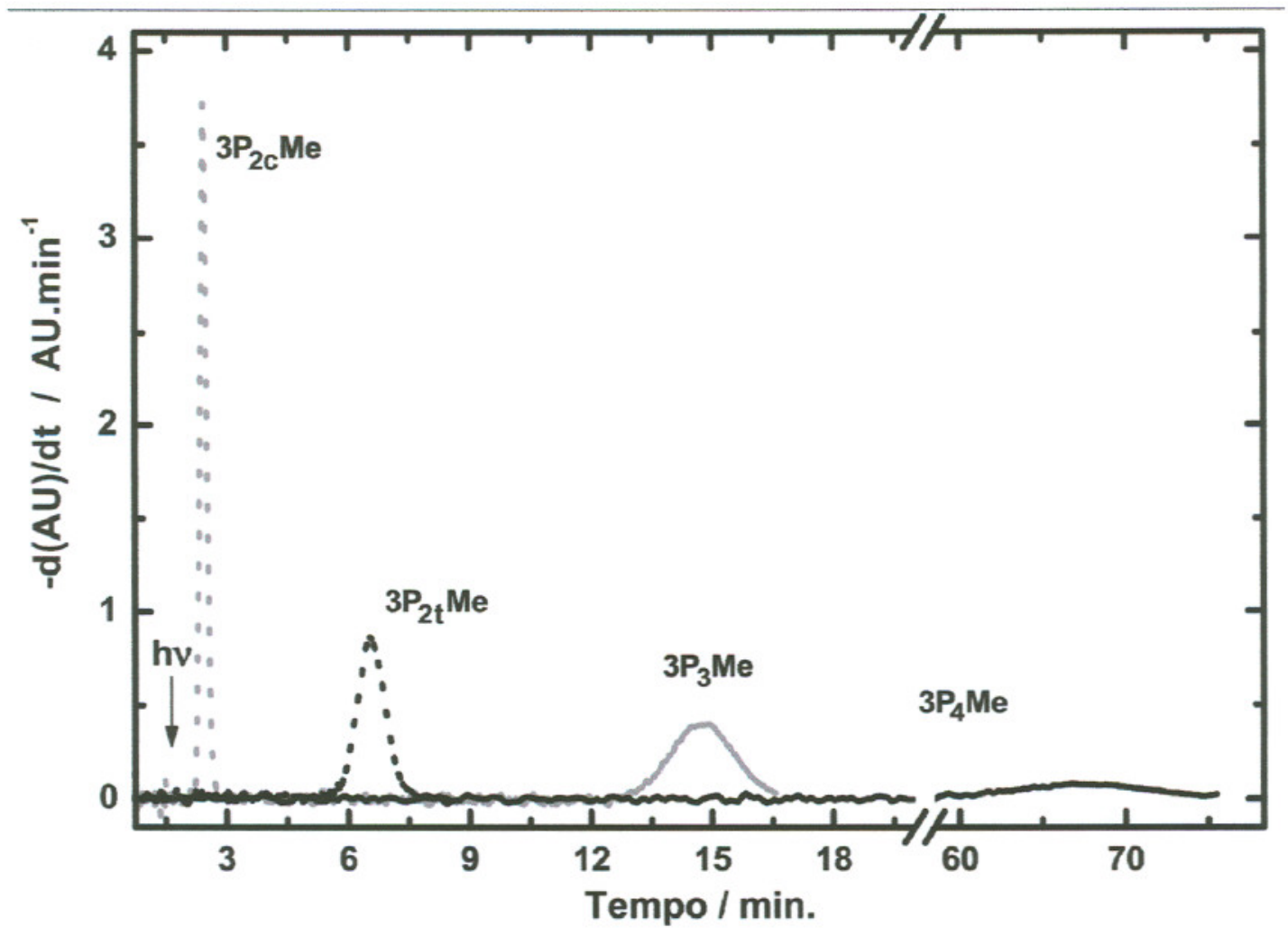

Figura 33: Derivada das curvas mostradas na figura $32 \mathrm{em}$ função do tempo para as porfirinas catiônicas da série $3 S \mathrm{Me}$ (irradiação em $532 \mathrm{~nm}, 20 \mathrm{~mW}$ ). 0 valor da derivada e o tempo para atingir o máximo podem ser relacionados com a velocidade de hemólise de eritrócitos e o tempo de indução.

As porfirinas da $4 \mathrm{SMe}$ apresentaram comportamento similar. Todavia, as espécies mais hidrofóbicas, como as $3 \mathrm{PMe}, 4 \mathrm{PMe}, 4 \mathrm{P}_{2 \mathrm{t}} \mathrm{Me}$, causaram hemólise instantaneamente após a adição de eritrócitos. Este efeito parece estar associado à baixissima solubilidade das mesmas em água, aliada a maior tendência de se associarem à membrana celular, provavelmente, formando grandes agregados. Estes provocariam a desestabilização da bicamada lipídica, tomando-a porosa e permitindo a entrada desordenada de água. Estes eventos provocariam 0 rompimento da membrana e 0 extravasamento do conteúdo intracelular. Comportamento hemolítico análogo, foi observado para as porfirinas das séries rutenadas, 3SRu e 4SRu, exceto para as mais hidrofilicas, $3 \mathrm{P}_{3} R u, 3 \mathrm{P}_{4} R u, 4 \mathrm{P}_{3} R u$ e $4 \mathrm{P}_{4} R u$. Nestes casos, os resultados foram praticamente independentes do número de complexos de 
rutênio, não apresentando correlação significativa entre a estrutura e a atividade. Este comportamento pode estar relacionado com a quebra da ligação rutênio-piridina (Ru-Py) nas condições do meio (elevada força iônica da solução de PBS). Em solventes orgânicos não coordenantes ou em água aquela ligação é bastante estável. Porém, ânions coordenantes como $\mathrm{Cl}^{-}$pode competir com as piridinas das porfirinas levando à dissociação dos complexos periféricos. Isto provocaria uma súbita diminuição do número de cargas positivas ligadas ao anel porfirínico e aumento da hidrofobicidade, acarretando um acentuado processo de agregação e a hemólise. Outra possibilidade seria a diminuição da solubilidade dos sensibilizadores porfirínicos e sua precipitação na membrana celular provocando o mesmo efeito. Por estes motivos, os demais experimentos descritos abaixo foram realizados apenas com as espécies metiladas, 3SMe e $4 \mathrm{SMe}$, por serem sistemas moleculares mais simples, estáveis e solúveis.

Na tentativa de contornar os problemas de hemólise que poderiam estar associados à agregação, as amostras foram inicialmente solubilizadas em uma solução de PBS contendo $0,07 \%$ (v/v) de Tween 20 , um tensoativo não iônico. Esta concentração do detergente mostrou ser a quantidade minima para prevenir a agregação daquelas espécies. Aliquotas da suspensão de eritrócitos foram adicionadas àquela solução e irradiadas como descrito anteriormente. Os resultados são mostrados nos gráficos da figura 34. Nota-se que os sensibilizadores porfirínicos apresentaram a eficiência decrescente na seguinte ordem para as porfirinas $4 \mathrm{SMe}: 4 \mathrm{P}_{2 \mathrm{c}} \mathrm{Me}>4 \mathrm{PMe}>4 \mathrm{P}_{2 \mathrm{t}} \mathrm{Me}>4 \mathrm{P}_{3} \mathrm{Me}>4 \mathrm{P}_{4} \mathrm{Me}$. $\mathrm{A}$ série dos isômeros meta (3SMe) apresentaram comportamento similar.

Interessantemente, as porfirinas monocationicas (3PMe e 4PMe) mesmo possuindo maiores log $\mathrm{P}_{\mathrm{OA}}$, ligam-se menos eficientemente à membrana celular que as $3 \mathrm{P}_{2 \mathrm{c}} \mathrm{Me}$ e $4 \mathrm{P}_{2 \mathrm{c}} \mathrm{Me}$. Este perfil sugere que as micelas presentes no meio competem com a membrana celular pela ligação das porfirinas. Ou seja, agora além do equilibrio, porfirina ligada ao eritrócito e livre no meio extra-celular, também existe o equilíbrio com as porfirinas ligadas às micelas de Tween 20. Neste caso em especifico, aparentemente a 3PMe e 4PMe apresentam maior afinidade pelas micelas. Neste caso, a transferência das moléculas de corante incorporadas nas micelas para a membrana só 
6.1.6 - Hemólise de eritrócitos

ocorrerá se houver a fusão entre ambas. Todavia, pela fusão da organela $e$ vesícula tratar-se de um processo cinético, as $\mathrm{PMe}$ e $\mathrm{P}_{2 \mathrm{c}} \mathrm{Me}$ podem apresentar eficiência de hemólise semelhantes, se o sistema for incubado por tempo suficientemente longo antes da irradiação.

Apesar dos resultados interessantes principalmente no caso das amostras mais hidrofóbicas, o uso do Tween 20 demonstrou ser inapropriado, pois foi observado um processo de hemólise induzida pelo próprio detergente, após cerca 6 minutos de adição dos eritrócitos. Este efeito pode ser observado na figura 34 onde se nota a lenta diminuição do espalhamento no caso da $4 \mathrm{P}_{4} \mathrm{Me}$. Curiosamente, 0 efeito hemolítico do Tween 20 parece ter sido suprimido ou reduzido significativamente na presença daquela porfirina tetracatiônica.

Todos os resultados apresentados neste capitulo, realizados em PBS ou na presença em Tween 20 (para as espécies mais hidrofóbicas) corroboram os resultados de coeficiente de partição. De fato, foi observado uma correlação linear entre as velocidades de hemólise e o log $\mathrm{POA}_{\mathrm{O}}$, como mostrado na figura 35. Este comportamento sugere que 0 efeito observado pode ser essencialmente atribuido ao equilibrio de partição dos fotossensibilizadores na membrana celular. A interação/incorporação provavelmente envolve a penetração dos grupos fenila hidrofóbicos na membrana. Neste caso, a porfirina dicatiônica, com cargas dispostas nas posições cis apresenta a vantagem de possuir uma estrutura anfipática, favorecendo a penetração dos grupos lipofilicos à membrana do eritrócito ao mesmo tempo que confere o grau de solubilidade suficiente à molécula. Ou seja, os isômeros cis apresentam o melhor compromisso de solubilidade e capacidade de ancoragem na membrana, maximizando a eficiência da reação de peroxidação lipidica foto-induzida. 
6.1.6- Hemólise de eritrócitos

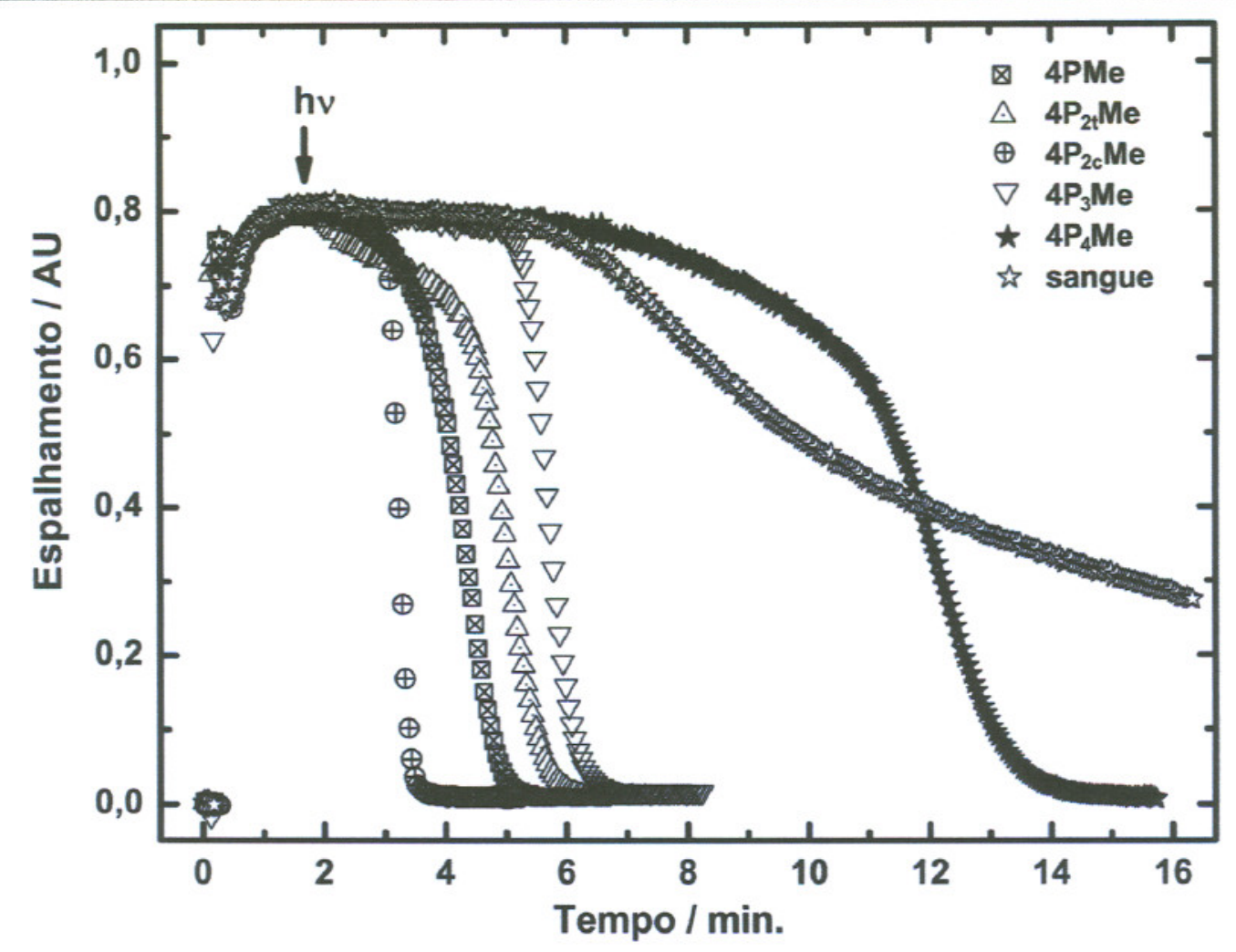

Figura 34: Intensidade de espalhamento $(e m 650 \mathrm{~nm}$ ) de soluções de $4 \mathrm{SMe}$, 4-piridilporfirinas metiladas ( 1,0 AU, $417 \mathrm{~nm}$ ), após a adição de eritrócitos e irradiação contínua com luz de $532 \mathrm{~nm}(20 \mathrm{~mW})$, em solução salina de fosfato (PBS) contendo $0,07 \%(\mathrm{v} / \mathrm{v})$ de Tween 20 . A seta indica o momento em que a irradiação foi iniciada.

Como demonstrado anteriormente, os valores de $\phi_{\Delta}$ das porfirinas da série 3SMe são praticamente equivalentes, ou seja, apresentam a mesma eficiência na formação de ${ }^{1} \mathrm{O}_{2}$ em solução de $\mathrm{D}_{2} \mathrm{O}$. Todavia, em solução aquosa o tempo de vida desta espécie é sensivelmente menor $(\sim 4 \mu s)[16,17]$. Além disso, devido às características hidrofóbicas da membrana celular, estima-se que a concentração de $\mathrm{O}_{2}$ dissolvida nesta região seja sensivelmente maior que no meio aquoso. Assim, os danos oxidativos à bicamada lipídica serão tão mais eficientes quanto mais próximos daquela estrutura $\mathrm{O}^{1} \mathrm{O}_{2}$ for gerado. Igualmente localizados nesta região encontram-se espécies antioxidantes naturais como, por exemplo, as vitaminas $A$ e $E$ que 


\subsection{6 - Hemólise de eritrócitos}

protegem temporariamente a membrana dos efeitos deletério do ${ }^{1} \mathrm{O}_{2}$. Esse efeito protetor deve ser um dos responsáveis pelo tempo de indução que antecede a hemólise foto-induzida, observados nas figuras 32 e 34 .

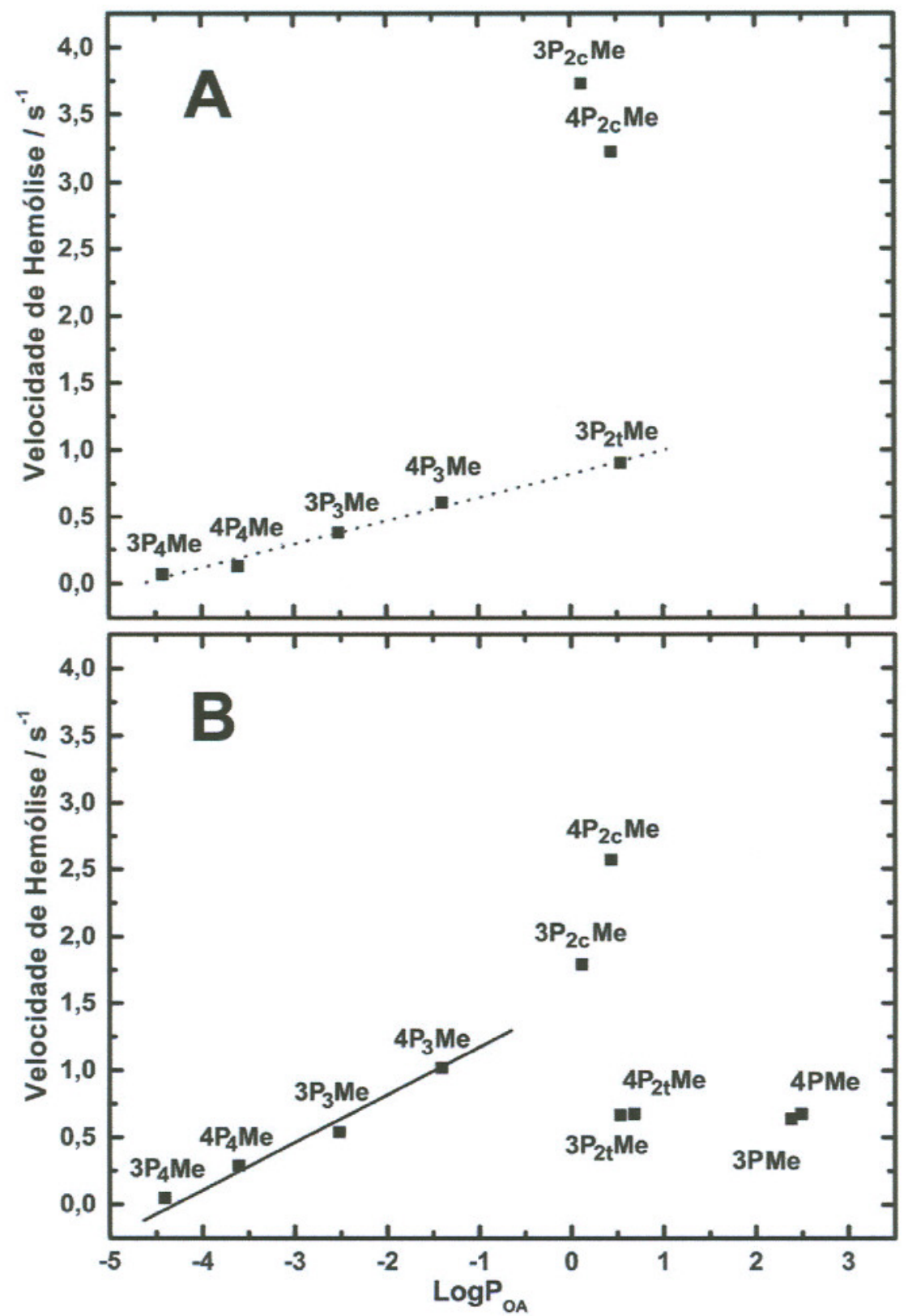

Figura 35: Gráficos mostrando a correlação linear entre o coeficiente de partição $n$-octanol/água $\left(\log \mathrm{P}_{\mathrm{OA}}\right)$ e as velocidades relativa de hemólise fotoinduzidas (532 nm, $20 \mathrm{~mW}$ ), utilizando as porfirinas metiladas das séries 3SMe e 4SMe como sensibilizadores A) em solução salina de tampão fosfato (PBS) e B) em solução de PBS contendo 0,07\% (v/v) de Tween 20. 
Em suma, os fotossensibilizadores porfirinicos catiônicos ligam-se à membrana celular de eritrócitos causando danos foto-oxidativos diferenciados de acordo com sua estrutura. A correlação linear encontrada entre a velocidade de hemólise e os dados de logP $\mathrm{P}_{\mathrm{OA}}$ corroboram os resultados. Todavia, um estudo da interação dos mesmos com mitocôndrias pode auxiliar na compreensão do mecanismo de incorporação, pois esta organela apresenta um potencial de membrana. Assim, pode-se investigar o efeito do fator eletrostático na interação/incorporação destes corantes catiônico realizando experimentos maximizando ou eliminando-se o potencial de membrana mitocondrial. Isto pode ser realizado energizando-se ou desacoplando-se a organela, respectivamente.

\subsubsection{INTERAÇÃO COM MITOCÔNDRIAS ISOLADAS}

Exceto pelo 3PMe e 4PMe, as porfirinas metiladas são bastante solúveis em água, mas apresentam processos de agregação quando a força iônica do meio é aumentada, especialmente no caso das porfirinas da série 4SMe. Este comportamento é mais pronunciado no caso da $\mathrm{P}_{2 c} \mathrm{Me}$ e $\mathrm{P}_{2 \mathrm{t}} \mathrm{Me}$, que adsorvem fortemente nas paredes do eppendorf, quando as amostras são centrifugadas. Todavia, a adição de uma pequena quantidade de mitocôndria foi suficiente para removê-las da superficie. Assim, para efeitos de cálculos, a concentração de porfirina no eppendorf que não continha mitocôndria foi considerada com sendo a concentração inicial. Neste relato, somente serão apresentados os gráficos referente a $3 \mathrm{SMe}$, pois a $4 \mathrm{SMe}$ apresentou comportamente similar.

A interação da porfirina com mitocôndrias é bastante rápida, necessitando-se de um pequeno tempo de incubação (menos de 5 minutos) para se atingir a condição de equilíbrio. Neste caso, a afinidade das porfirinas catiônicas com a mitocôndria pode ser qualitativamente avaliada pela simples visualização da coloração do precipitado centrifugado. Por exemplo, no caso das $\mathrm{P}_{2 c} \mathrm{Me}$ e $\mathrm{P}_{2 \dagger} \mathrm{Me}$, os precipitados adquiriram nítida coloração violeta enquanto que no caso das $\mathrm{P}_{3} \mathrm{Me}$ e $\mathrm{P}_{4} \mathrm{Me}$ permaneceram quase brancos. Esta 
6.1.7 - Interação com Mitocândrias Isoladas

evidência qualitativa foi confirmada quando se mediu as frações de porfirina contidas no sólido e no sobrenadante. Os gráficos mostrando como aqueles valores variam em função do aumento da proporção de mitocôndria na mistura para a série de porfirinas são mostrados na figura 36. Curvas de distribuição típicas foram obtidas indicando a existência de um equilibrio envolvendo as frações de porfirinas ligada e livre. Também, pode-se perceber nitidamente que há um aumento progressivo da concentração de porfirina ligada à medida que diminui o número de grupos $N$-metilpiridínio das porfirinas. Este resultado confirma nossa asserção anterior de que a eficiência de hemólise está relacionada com a eficiência de partição e, portanto, com os valores de Log

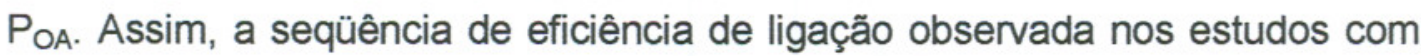
mitocôndrias, ou seja, $3 \mathrm{P}_{2 c} \mathrm{Me}>3 \mathrm{P}_{2 t} \mathrm{Me}>3 \mathrm{P}_{3} \mathrm{Me}>3 \mathrm{P}_{4} \mathrm{Me}$, foi a mesma dos estudos de hemólise. A superioridade do isômero dicatiônico cis em relação ao trans se manteve, sendo que foram necessários apenas $0,025 \mathrm{mg} \cdot \mathrm{mL}^{-1}$ de mitocôndria para diminuir a concentração de $3 \mathrm{P}_{2 \mathrm{c}} \mathrm{Me}$ livre para metade da concentração inicial. No caso das porfirinas $3 \mathrm{P}_{2 \mathrm{t}} \mathrm{Me}, 3 \mathrm{P}_{3} \mathrm{Me}$ e $3 \mathrm{P}_{4} \mathrm{Me}$ esta mesma condição foi alcançada após adição de $0,11,0,43$ e $0,7 \mathrm{mg} \cdot \mathrm{mL}^{-1}$ de mitocôndria, respectivamente. 
6.1.7 - Interação com Mitocândrias Isoladas
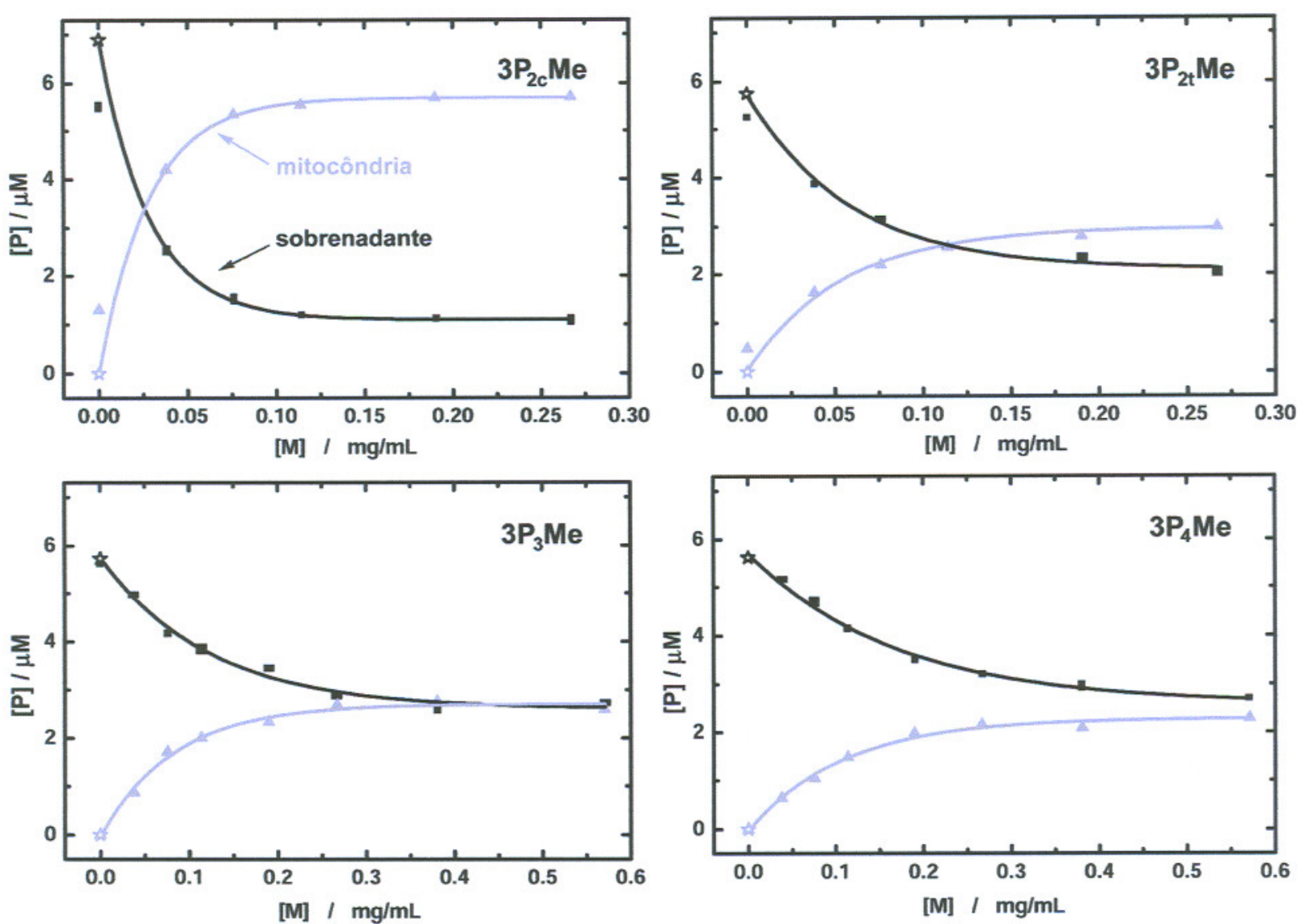

Figura 36: Variação da concentração de porfirina da $35 \mathrm{Se}$, ligada à mitocôndria ( - cinza) e livre na solução (" - preto) em função da concentração inicial de mitocôndria ([M]). Para o ajuste da curva o primeiro ponto $([M]=0)$ foi considerado com sendo a concentração inicial de porfirina ( $\star, \sim 6 \mu \mathrm{M}$ ), devido ao processo de adsorção às paredes do eppendorf quando na ausência de mitocôndria, como explicado no texto.

Em estudos similar, de ligação de fotossensibilizadores à mitocôndrias isoladas, Gabrielli e colaboradores [30] observaram um acentuado processo de decomposição, quando utilizavam azul de metileno como corante. Para verificar a ocorrência deste tipo de reação em nossos experimentos, a quantidade total de porfirina, antes e após o equilibrio de partição, foram analisadas. Diferentemente dos resultados obtidos por Gabrielli et alli, não foi 
6.1.7 - Interação com Mitocândrias Isoladas

observada nenhuma evidência de decomposição das porfirinas incorporadas, pois a quantidade do fotossensibilizador extraída do precipitado foi similar à calculada pela subtração da concentração das porfirinas inicial e livre.

O experimento inverso, ou seja, a verificação do número máximo de moléculas de porfirinas para se atingir a saturação das mitocôndrias foi estimada variando-se a concentração inicial de porfirina e mantendo a concentração mitocondrial constante $\left(0,22 \mathrm{mg} \cdot \mathrm{mL}^{-1}\right)$.

A $3 P_{2 t} \mathrm{Me}$ (figura 37) apresentou uma capacidade de ligação pouco superior a $3 \mathrm{P}_{3} \mathrm{Me}$ e $3 \mathrm{P}_{4} \mathrm{Me}$, que mostraram resultados similares entre si $(2,5 \mu \mathrm{M})$. Além disso, na primeira é possível visualizar uma pequena região $\left(\left[\mathrm{P}_{\text {ini }}\right]<2,5 \mu \mathrm{M}\right)$ onde a concentração de porfirina ligada à mitocôndria (em cinza) é maior que a livre (em preto). A $3 \mathrm{P}_{2 c} \mathrm{Me}$ apresentou a maior capacidade de incorporação sendo necessário mais de $20 \mu \mathrm{M}$ de porfirina para saturar a mesma quantidade de mitocôndria. Desta forma, a capacidade de incorporação máxima de porfirina em mitocôndria foi estimada como sendo aproximadamente $110,23,13$ e 13 nmols. $\mathrm{mg}^{-1}$ para $3 \mathrm{P}_{2 \mathrm{c}} \mathrm{Me}$, $3 \mathrm{P}_{2 \mathrm{t}} \mathrm{Me}, 3 \mathrm{P}_{3} \mathrm{Me}$ e $3 \mathrm{P}_{4} \mathrm{Me}$, respectivamente. 
6.1.7 - Interação com Mitocândrias Isoladas
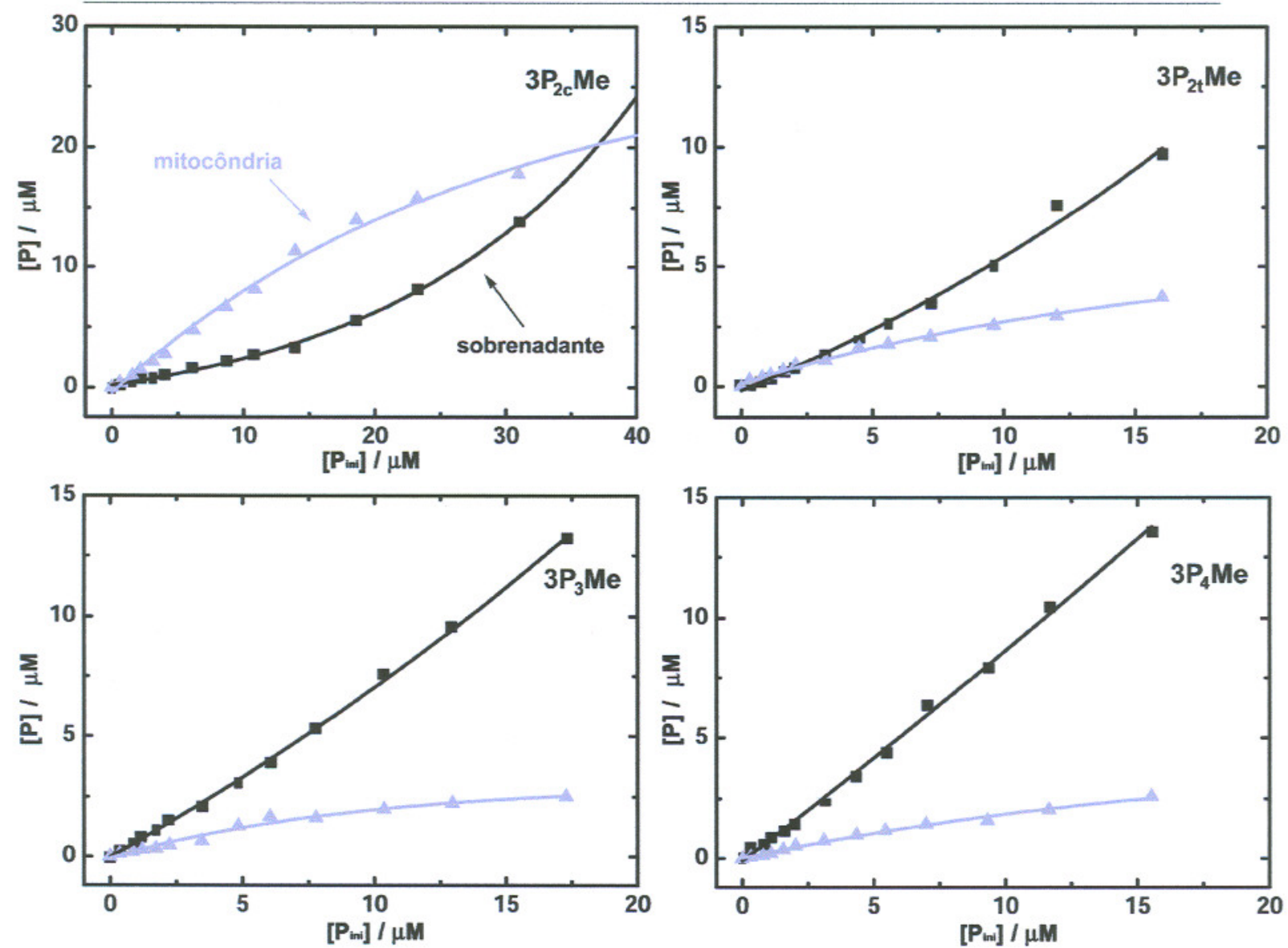

Figura 37: Variação da concentração de porfirina ([P]) da série 3, ligada à mitocôndria ( $\Delta$ - cinza) e livre na solução ( - preto) em função do aumento da concentração inicial de porfirina $\left(\left[P_{\text {ini }}\right]\right)$, mantendo-se a concentração de mitocôndria constante $\left([\mathrm{M}]=0,22 \mathrm{mg} \cdot \mathrm{mL}^{-1}\right)$.

As constantes de ligação das porfirinas à mitocôndria ( $\mathrm{K}_{\mathrm{L}}{ }^{\mathrm{M}}$; figura 38$)$ foram calculadas utilizando-se a equação 9 e os dados mostrados na figura 36 . Percebe-se que há uma satisfatória correlação linear de $\mathrm{K}_{\mathrm{L}}{ }^{\mathrm{M}}$ em função do aumento do caráter lipofilico das moléculas, exceto no caso das espécies dicatiônicas em cis, $3 \mathrm{P}_{2 c} \mathrm{Me}$ e $4 \mathrm{P}_{2 c} \mathrm{Me}$. Nota-se que as constantes de ligação para essas duas estruturas são muito maiores que para as demais espécies, sendo cerca de 4,7 e 17 vezes superior a das $P_{2 t} M e, P_{3} M e$ e $P_{4} M e$, respectivamente. 
6.1.7 - Interação com Mitocândrias Isoladas

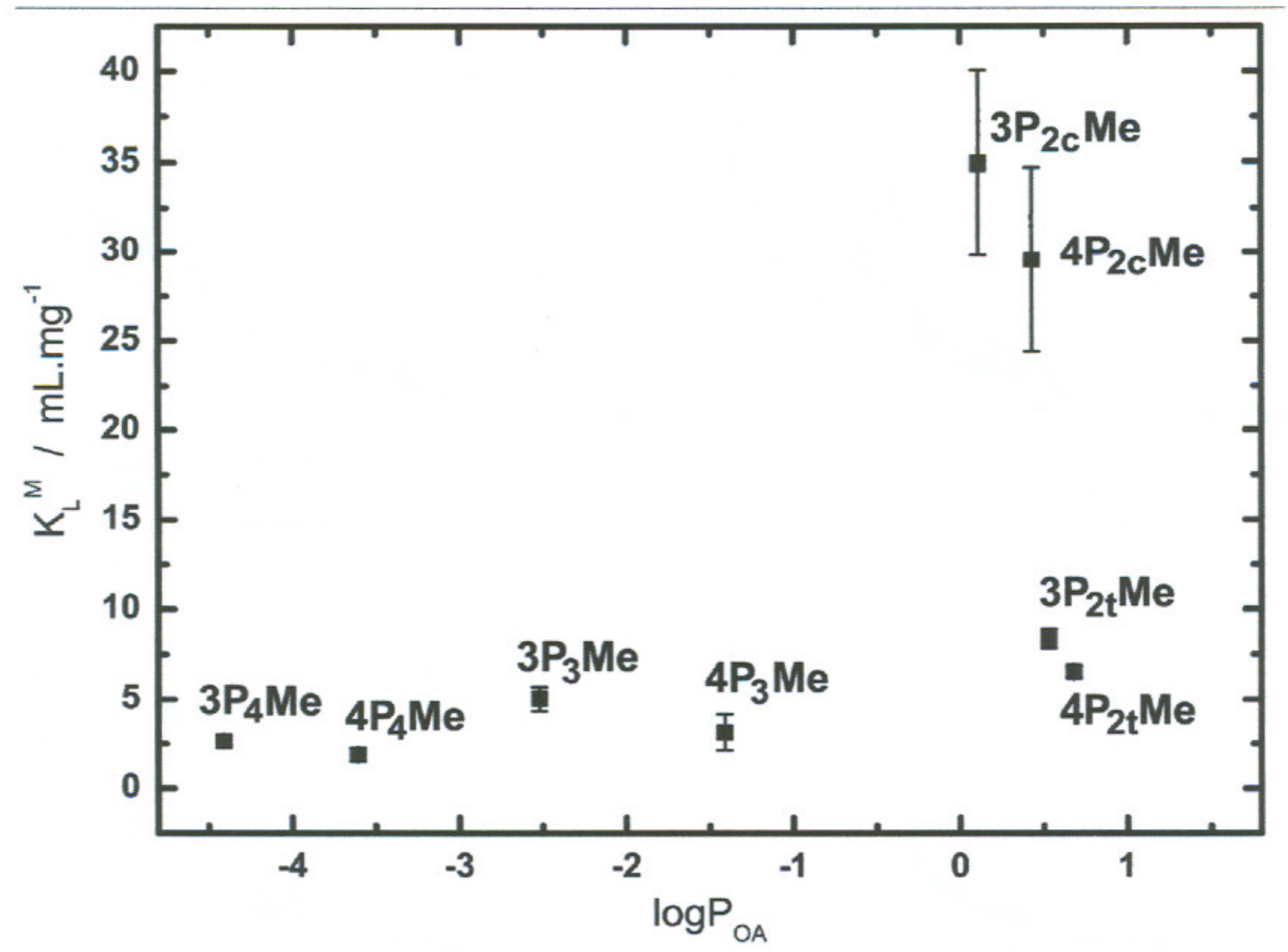

Figura 38: Gráfico das constantes de ligação à mitocôndria $\left(K_{L}{ }^{M}-\right.$ - $)$ em função do coeficiente de partição (log $\left.\mathrm{P}_{\mathrm{OA}}\right)$ para as porfirinas catiônicas das séries $3 \mathrm{SMe}$ e $4 \mathrm{SMe}$. Os valores são à média ( \pm erro) de pelo menos 3 experimentos independentes, à $25^{\circ} \mathrm{C}$.

Semelhantemente aos experimentos com eritrócitos, o espalhamento de uma solução de porfirina contendo mitocôndrias foi monitorado em função do tempo de irradiação com um laser portátil com emissão em $532 \mathrm{~nm}(20 \mathrm{~mW})$. Somente na presença de porfirina e irradiação foi possivel observar a diminuição do espalhamento. Na ausência de qualquer um destes dois componentes, nenhuma variação espectral pôde ser observada. Neste caso, a diminuição do espalhamento é atribuído ao inchamento daquelas organelas. A reação com ${ }^{1} \mathrm{O}_{2}$, formado pela irradiação das porfirinas, com os fosfolipídios geram poros na membrana, permitindo a entrada de um grande volume de água para $\circ$ interior. Esta expansão diminui a espessura das paredes, que passam a espalhar menos a luz.

\begin{tabular}{ll}
\hline Fábio Monaro Engelmann & Tese de Doutorado \\
ib Química- USP
\end{tabular}

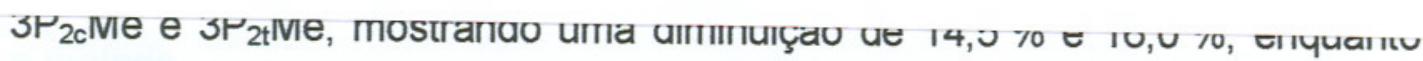
que $\mathrm{o}$ efeito foi menos evidente no caso da $3 \mathrm{P}_{3} \mathrm{Me}$ e $3 \mathrm{P}_{4} \mathrm{Me}(8,2$ e 7,4 \%), respectivamente.

Estes resultados sugerem que o potencial elétrico mitocondrial exerce uma força de atração nas porfirinas catiônicas, contribuindo para aumentar a 
6.1.7 - Interação com Mitocândrias Isoladas
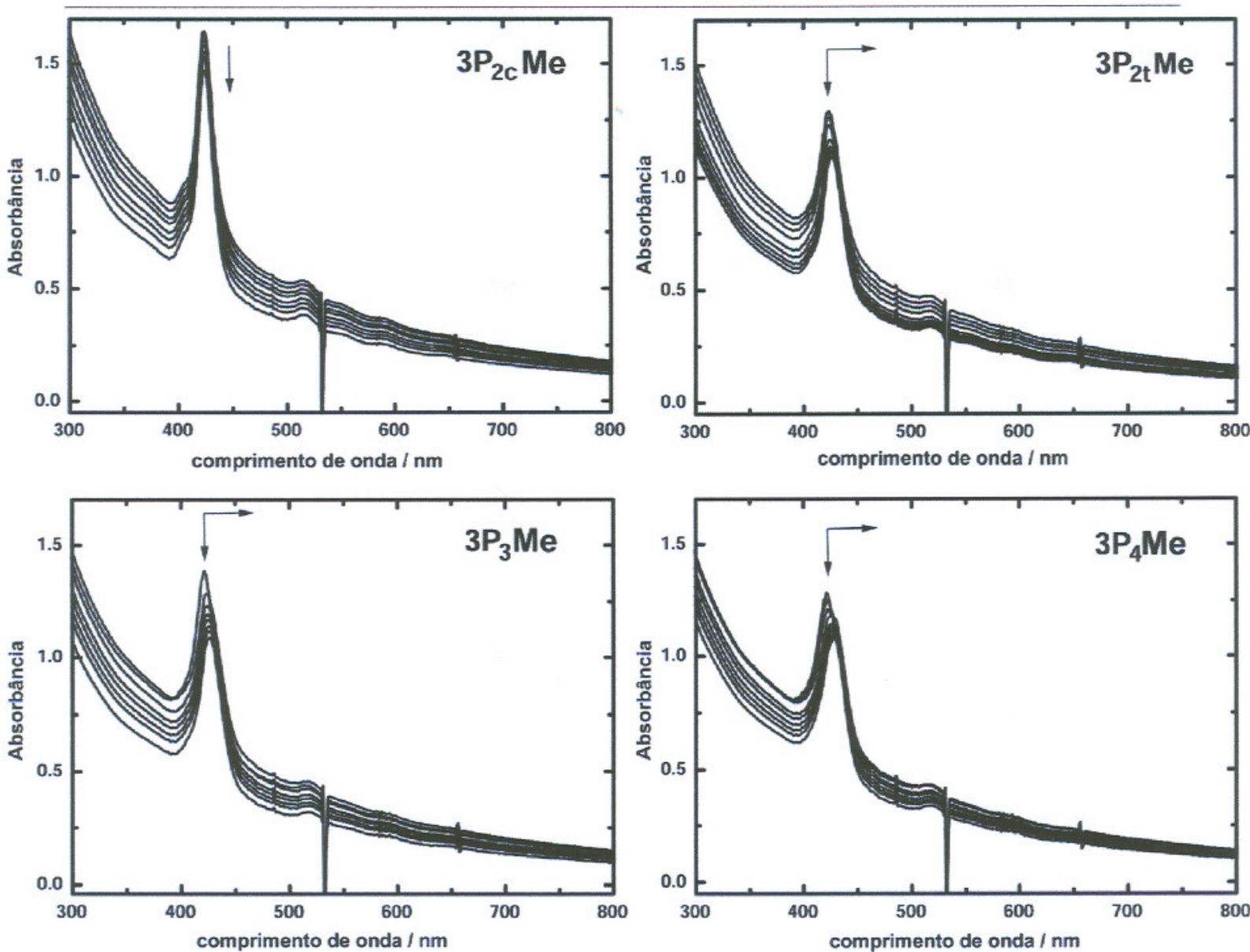

Figura 39: Variação do espectro de absorção da 3SMe $(\sim 5 \mu \mathrm{M})$ contendo $0,15 \mathrm{mg} \cdot \mathrm{mL}^{-1}$ de mitocôndria sob constante irradiação $(532 \mathrm{~nm}, 20 \mathrm{~mW})$ e agitação magnética. O pico negativo observado em $532 \mathrm{~nm}$ é atribuido à luz espalhada do laser de irradiação.

Além de uma diminuição da linha base dos espectros devido à diminuição do espalhamento, também pode-se perceber o deslocamento da banda Soret de 422 para $426 \mathrm{~nm}$, para todas as porfirinas da 3SMe (figura 39), exceto a espécie $3 \mathrm{P}_{2} \mathrm{Me}$. Isto pode sugerir que esta última esteja mais fortemente ligada à membrana, mantendo-se associada à mesma mesmo após o processo de inchamento da organela. As demais porfirinas tenderiam a se dissociar, indo para a solução. 
A eficiência dos sensibilizadores porfirínicos em causar danos às mitocôndrias foi estudada monitorando-se a variação de absorbância (espalhamento) em função do tempo (figura 40). Neste caso, foi observado um aumento progressivo da absorbância com o início da irradiação atingindo um máximo, a partir do qual ocorre um declinio mais ou menos rápido em função do tempo. Ainda não se sabe o porque do aumento inicial do espalhamento, mas deve estar associado ao tempo de indução observado nos experimentos de hemólise dos eritrócitos. Pode-se constatar um comportamento similar aquele encontrado nos demais experimentos descritos até o momento. Ou seja, uma maior eficiência em causar danos para as porfirinas $3 \mathrm{P}_{2 \mathrm{c}} \mathrm{Me} \mathrm{e}$ $3 \mathrm{P}_{2 \mathrm{t}} \mathrm{Me}$ em relação à $3 \mathrm{P}_{3} \mathrm{Me}$ e $3 \mathrm{P}_{4} \mathrm{Me}$. Todavia, diferentemente dos resultados anteriores, neste caso foi observada uma grande similaridade entre as eficiências dos dois isômeros dicatiônicos. Esta semelhança pode ser atribuida à elevada concentração $(\sim 4 \mu \mathrm{M})$ destes fotossensibilizadores em relação à concentração de mitocôndria $\left(0,15 \mathrm{mg} \cdot \mathrm{mL}^{-1}\right)$. Em baixas concentrações do corante, uma diferença mais pronunciada dever ser observada.

Entretanto, tendências bem diferentes foram observadas para cada porfirina. $\mathrm{A} 3 \mathrm{P}_{4} \mathrm{Me}$ apresentou um maior tempo de indução antes do início do processo de inchamento (quase 3 minutos), seguido pela $3 \mathrm{P}_{3} \mathrm{Me}$ (1 minuto) e as duas porfirinas dicatiônicas ( $30 \mathrm{~s}$ ). Estes resultados novamente confirmam que existem diferenças na localização ou penetração destes corantes nas membranas celulares e agora também na membrana mitocondrial. Assim, a $3 \mathrm{P}_{4} \mathrm{Me}$ deve estar interagindo com a superficie da membrana fazendo com que o processo de peroxidação lipídica ocorra mais lentamente que no caso da $3 \mathrm{P}_{3} \mathrm{Me}$, que apresenta um ponto de ancoragem, ou seja, penetra na membrana. Assim, a lipoperoxidação deve ser mais rápida e eficiente no caso da $3 \mathrm{P}_{2 c} \mathrm{Me}$ e $3 \mathrm{P}_{2 t} \mathrm{Me}$ porque estas tem maior capacidade de penetração, praticamente incorporando-se na membrana. A possibilidade de reação da porfirina com espécies intra-mitocondriais pode ser descartada, pois nenhuma variação de absorbância foi observada em 480 ou $515 \mathrm{~nm}$ durante os experimentos. 


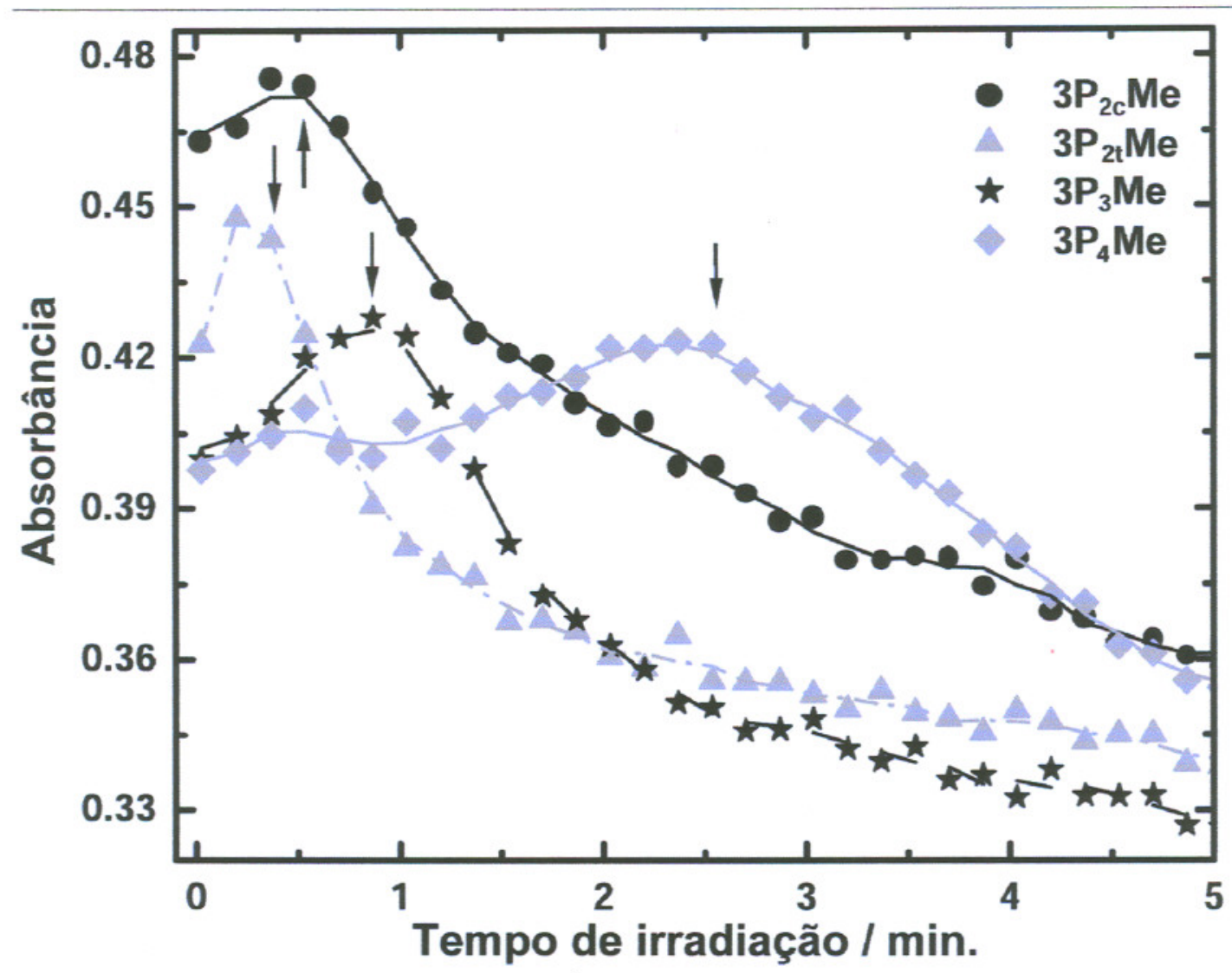

Figura 40: Variação da absorção em $480 \mathrm{~nm}$ da $3 \mathrm{SMe}(\sim 5 \mu \mathrm{M})$, contendo $0.15 \mathrm{mg} \cdot \mathrm{mL}^{-1}$ de mitocôndria sob constante irradiação $(532 \mathrm{~nm}, 20 \mathrm{~mW})$ e agitação magnética. A seta mostra o início do processo de inchamento.

Os ensaios investigando a influência do potencial de membrana mitocondrial sobre a eficiência da ligação destes fotossensibilizadores mostraram uma pequena diminuição na concentração de porfirina ligada quando a mitocôndria foi desacoplada. A redução na taxa de ligação, em relação a mitocôndria energizada, foi mais sensivel no caso das porfirinas $3 \mathrm{P}_{2 c} \mathrm{Me}$ e $3 \mathrm{P}_{2 \mathrm{t}} \mathrm{Me}$, mostrando uma diminuição de $14,5 \%$ e $16,0 \%$, enquanto que 0 efeito foi menos evidente no caso da $3 \mathrm{P}_{3} \mathrm{Me}$ e $3 \mathrm{P}_{4} \mathrm{Me}(8,2$ e $7,4 \%)$, respectivamente.

Estes resultados sugerem que o potencial elétrico mitocondrial exerce uma força de atração nas porfirinas catiônicas, contribuindo para aumentar a 
constante de interação. Porém, aparentemente o efeito é de maior amplitude quando os fotossensibilizadores apresentam regiões lipofilicas para ligação à membrana. Ou seja, a atração eletrostática entre a mitocôndria e as cargas positivas dos fotossensibilizadores contribui significativamente quando elas estão ancoradas na membrana, aproximando os sítios positivamente carregados da sua superfície.

A influência da estrutura dos fotossensibilizadores na eficiência fotodinâmica dos mesmos já ficou bastante evidente. Entretanto uma questão ainda não foi totalmente esclarecida. A interação com a membrana ocorre de maneira não especifica ou depende da presença de sítios específicos de reconhecimento molecular? Esta questão torna-se ainda mais interessante quando se compara o comportamento distinto dos isômeros cis em relação aos trans e às demais espécies. Na tentativa de esclarecer esta questão um experimento similar foi conduzido em sistemas modelo de lipossomos, composto de uma mistura de dois fosfolipidios na tentativa de mimetizar a membrana mitocondrial.

\subsubsection{INTERAÇÃO COM LIPOSSOMOS}

Os estudos foram realizados utilizando a mesma metodologia utilizada no caso das mitocôndrias e os resultados são mostrados na figura 41. Nota-se que o comportamento do sistema lipossomo/porfirinas catiônicas é similar ao do sistema mitocôndria/porfirinas catiônicas, apresentando curvas de titulação com perfis típicos de equilíbrios de partição. Uma pequena quantidade de lipossomos $(0,1 \mathrm{mM})$ foi suficiente para remover completamente a $3 \mathrm{P}_{2 c} \mathrm{Me}$ livre em solução, mas não foi suficiente para reduzir a concentração da $3 \mathrm{P}_{4} \mathrm{Me}$ para a metade.

Analogamente ao que ocorreu no caso dos experimentos com mitocôndrias, as constantes de ligação foram muito sensiveis a força iônica do meio. Mas, como explicado anteriormente, isso se deve a processos de agregação, precipitação dos fotossensibilizadores. Para minimizar tais efeitos e 
6.1.8 - Interação com Lipossomos

viabilizar os experimentos, neste caso também os estudos foram realizados em água.
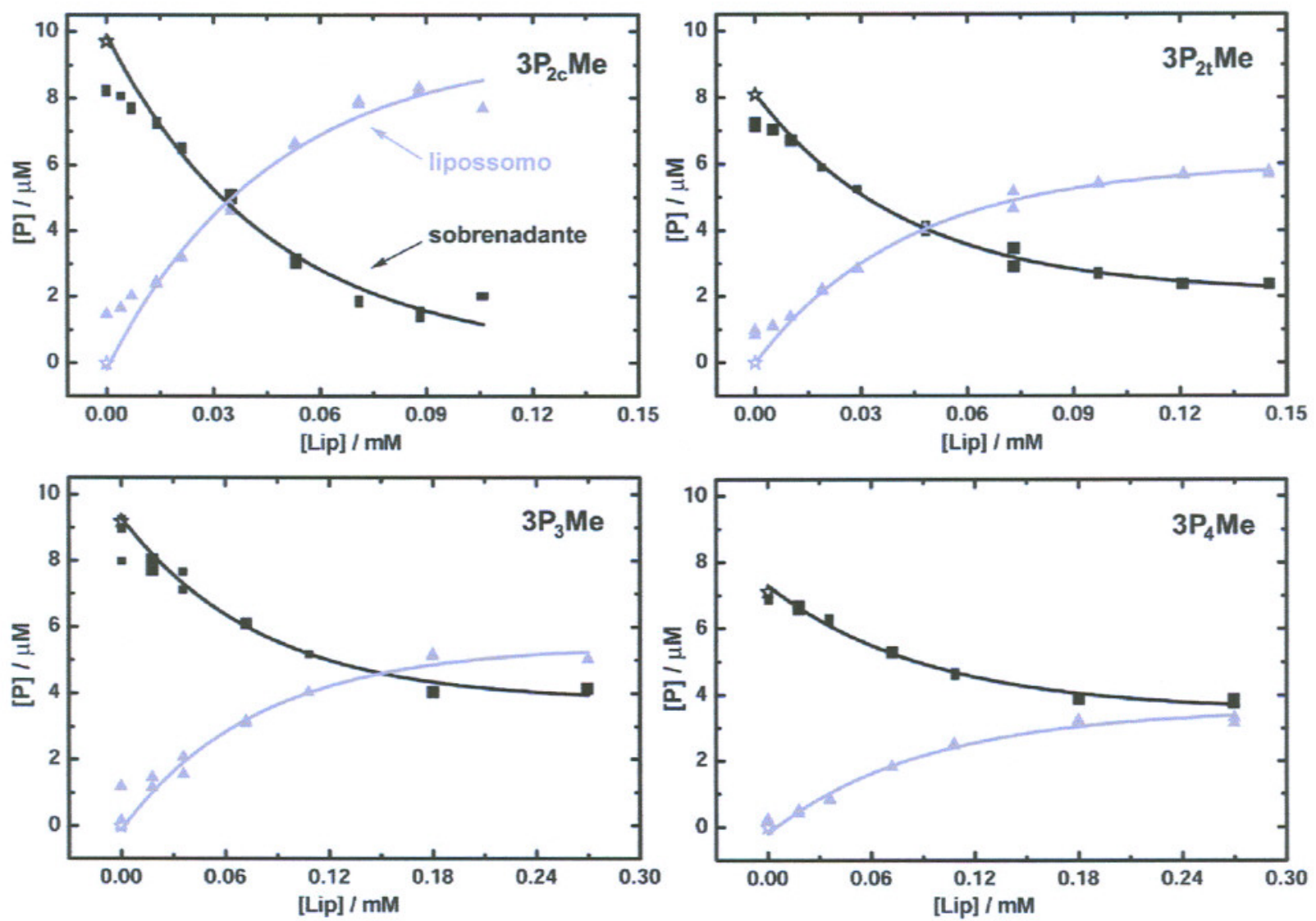

Figura 41: Variação da concentração das porfirinas da série 3SMe, ligada aos lipossomos ( 4 - cinza) e livre em solução ( - preto), em função do aumento da concentração total de lipossomos ([Lip]) em tampão Tris/HCl 5 mM, pH7,2. Devido à adsorção das porfirinas nas paredes do eppendorf, o primeiro ponto ([Lip] $=0)$ foi considerado com sendo a concentração inicial de porfirina ( $k, \sim 8 \mu \mathrm{M}$ ) e os 4 pontos seguintes foram desconsiderados no processe de ajuste de curvas.

As constantes de ligação das séries de porfirinas catiônicas com lipossomos, $\mathrm{K}_{\mathrm{L}}{ }^{\mathrm{L}}$ (figura 42 , tabela 6 ), também variam linearmente em função do 
6.1.8 - Interação com Lipossomos

número de grupos fenila, apresentando a seguinte seqüência: $3 \mathrm{P}_{2 \mathrm{c}} \mathrm{Me}>3 \mathrm{P}_{2 \mathrm{t}} \mathrm{Me}>3 \mathrm{P}_{3} \mathrm{Me}>3 \mathrm{P}_{4} \mathrm{Me}$. Estes resultados foram bastante interessantes e esclarecedores, pois mostraram o mesmo comportamento observado com mitocôndrias isoladas e com eritrócitos, sugerindo fortemente que a ligação destes compostos à aquelas estruturas biológicas não ocorre por sítios de reconhecimento molecular específicos, mas por partição a bicamada lipidica.

Mesmo as elevadas constantes dos isômeros dicatiônico cis não podem ser atribuidas a interação com receptores, mas a aspectos físico-químicos decorrentes da orientação dos sítios eletricamente carregados, ou seja, à estrutura molecular do fotossensibilizador.

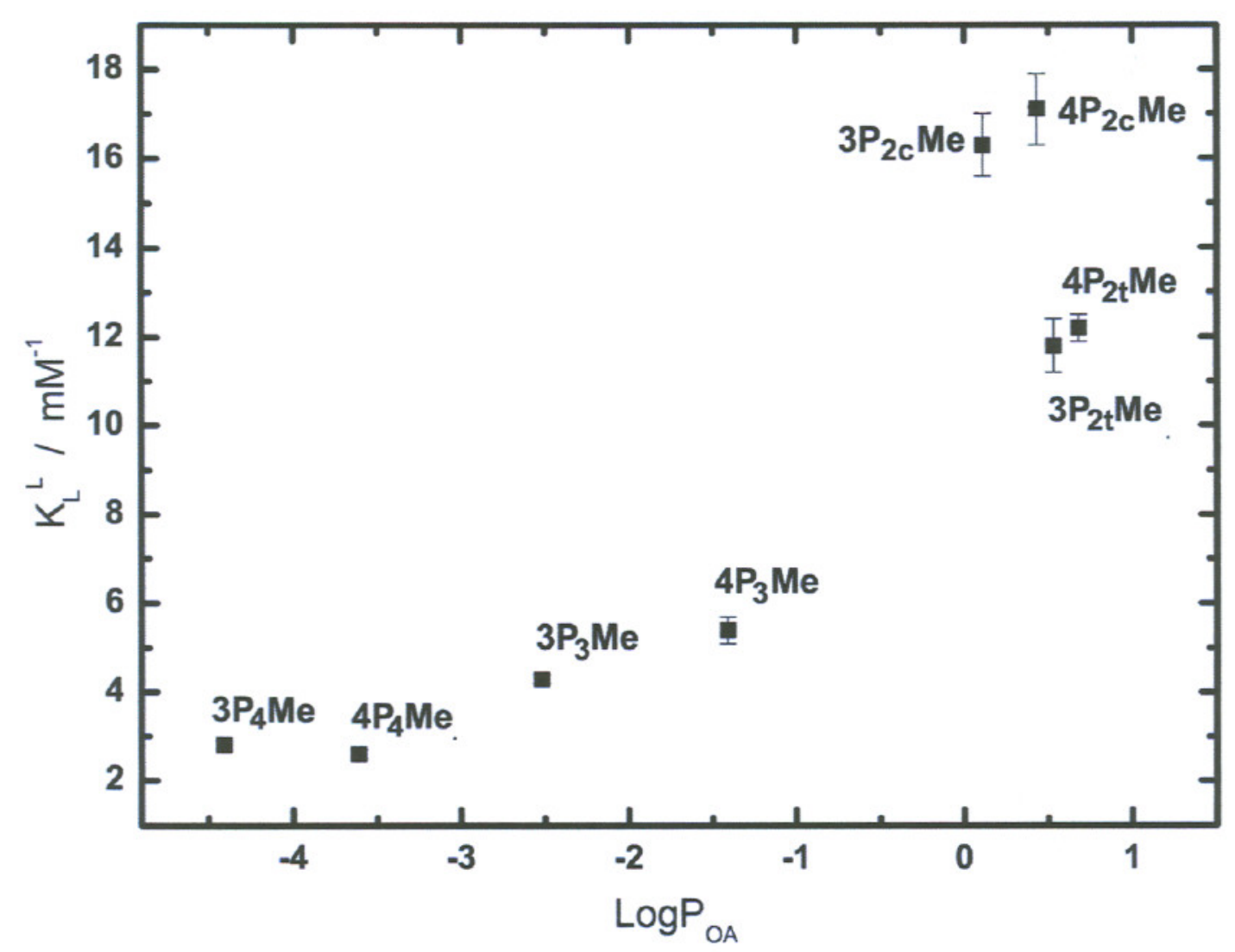

Figura 42: Gráfico correlacionando as constantes de ligação das porfirinas aos lipossomos $\left(\mathrm{K}_{\mathrm{L}}{ }^{\mathrm{L}}\right.$ - $\left.\mathbf{a}\right)$ com o coeficiente de partição (log $\left.\mathrm{P}_{\mathrm{OA}}\right)$ para as porfirinas cationicas das séries $3 \mathrm{SMe}$ e $4 \mathrm{SMe}$. Os valores são a média ( \pm erro) de pelo menos 3 experimentos independentes à $25^{\circ} \mathrm{C}$. 
6.1.8 - Interação com Lipossomos

Tabela 6: Rendimento quântico de formação de ${ }^{1} \mathrm{O}_{2}\left(\phi_{\Delta} \pm 0,05\right)$ em $\mathrm{D}_{2} \mathrm{O}$, coeficientes de partição n-octanol/água $\left(\log \mathrm{P}_{\mathrm{OA}}\right)$ e constantes de ligação à mitocôndria $\left(\mathrm{K}_{\mathrm{L}}{ }^{\mathrm{M}}\right)$ e à lipossomos $\left(\mathrm{K}_{\mathrm{L}}{ }^{\mathrm{L}}\right)$ (DSPC/CL 8:2).

\begin{tabular}{|c|c|c|c|c|}
\hline & $\phi_{\Delta}\left(D_{2} \mathrm{O}\right)$ & $\log P_{O A}$ & $\mathrm{~K}_{\mathrm{L}}^{\mathrm{M}}\left(\mathrm{mL} \cdot \mathrm{mg}^{-1}\right)$ & $\mathrm{K}_{\mathrm{L}}{ }^{\mathrm{L}} \times 10^{-3}\left(\mathrm{M}^{-1}\right)$ \\
\hline $3 \mathrm{P}_{2 \mathrm{c}} \mathrm{Me}$ & 0,91 & $0,11 \pm 0,08$ & $34,93 \pm 5,11$ & $16,3 \pm 0,7$ \\
\hline $3 \mathrm{P}_{2 t} \mathrm{Me}$ & 0,86 & $0,53 \pm 0,09$ & $8,37 \pm 0,53$ & $11,8 \pm 0,6$ \\
\hline $3 \mathrm{P}_{3} \mathrm{Me}$ & 0,91 & $-2,52 \pm 0,09$ & $5,04 \pm 0,66$ & $4,3 \pm 0,1$ \\
\hline $3 \mathrm{P}_{4} \mathrm{Me}$ & 0,89 & $-4,41 \pm 0,05$ & $2,67 \pm 0,19$ & $2,8 \pm 0,1$ \\
\hline $4 \mathrm{P}_{2 \mathrm{c}} \mathrm{Me}$ & 0,64 & $0,43 \pm 0,08$ & $29,55 \pm 5,15$ & $17,1 \pm 0,8$ \\
\hline $4 \mathrm{P}_{2 \mathrm{t}} \mathrm{Me}$ & 0,61 & $0,68 \pm 0,05$ & $6,53 \pm 0,30$ & $12,2 \pm 0,3$ \\
\hline $4 \mathrm{P}_{3} \mathrm{Me}$ & 0,72 & $-1,41 \pm 0,09$ & $3,17 \pm 1,02$ & $5,4 \pm 0,3$ \\
\hline $4 \mathrm{P}_{4} \mathrm{Me}$ & 0,90 & $-3,61 \pm 0,09$ & $1,89 \pm 0,36$ & $2,6 \pm 0,1$ \\
\hline
\end{tabular}

Os resultados até o momento, contribuíram para elucidar definitivamente o mecanismo de interação das séries de porfirinas catiônicas com estruturas celulares tais como eritrócitos e mitocôndrias. Uma correlação clara entre a atividade fotodinâmica com a estrutura foi verificada. Também constatou-se que o LogP $\mathrm{PA}_{\mathrm{A}}$ é um bom parâmetro para se prever tal atividade, exceto no caso dos isômeros cis e, provavelmente, de todos os compostos com caráter anfipáticos. Todavia, células tumorais apresentam atividades bastante distintas de células comuns e principalmente de eritrócitos. Sendo assim, o próximo passo consistiu em estudar a interação e atividade fotodinâmica com células tumorais. 


\subsubsection{INTERAÇÃO COM FIBROBLASTOS CANCEROSOS HE-LA}

As taxas de ligação das porfirinas da série $3 \mathrm{SMe}$ às células tumorais HeLa em função do tempo de incubação são mostradas na figura 43. Nota-se que o tempo necessário para se atingir o equilibrio é menor quanto maior é a contante de interação. De uma maneira geral, os experimentos cinéticos apresentaram um comportamento similar ao dos observados anteriormente com mitocôndrias e lipossomos, onde os isômeros com dois grupos $\mathrm{N}$ metilpiridinio apresentam as maiores constantes de interação.

Como pode-se observar nos gráficos da figura 43 , enquanto a fração de porfirina ligada aos fibroblastos foi bastante elevada no caso da $3 \mathrm{P}_{2 \mathrm{c}} \mathrm{Me} \mathrm{e}$ $3 \mathrm{P}_{2 \dagger} \mathrm{Me}$, nota-se que apenas uma pequena fração da $3 \mathrm{P}_{3} \mathrm{Me}$ e $3 \mathrm{P}_{4} \mathrm{Me}$ se ligaram àquelas células. De fato, aproximadamente 80 e $70 \%$ dos isômeros cis e trans das porfirinas dicationicos, respectivamente, se ligaram às células. Além disso, suas velocidades de ligação também foram bastante elevadas, sendo necessários apenas 12 e 67 minutos, respectivamente, para reduzir a concentração daquelas porfirinas livres na solução em $50 \%$. Apesar das constantes de ligação da $3 \mathrm{P}_{3} \mathrm{Me}$ e da $3 \mathrm{P}_{4} \mathrm{Me}$ serem relativamente pequenas ( 3,7 e 1,8\%, respectivamente, se ligaram após 4 horas) o equilibrio parece ter sido atingido em tempos comparáveis. As constantes de associação tendem a aumentar rapidamente com a diminuição do número de grupos $\mathrm{N}$-metilpiridinio, seguindo um comportamento análogo aos casos anteriormente descritos. Considerando-se que o número de células e a concentração das porfirinas em todos os experimentos é constante, pode-se verificar que o isômero cis tem uma relação de porfirina ligada e livre igual a 1,7 e 200 vezes maior que do isômero trans e do $3 \mathrm{P}_{3} \mathrm{Me}$, respectivamente. Assim, pode-se notar que neste caso também existe uma diferença significativa entre as constantes de ligação dos isômeros cis e trans. Logo, o Log $\mathrm{P}_{\mathrm{OA}}$ parece ser um bom parâmetro para se prever as constantes de ligação das porfirinas catiônicas com a membrana celular da HeLa. Porém, a correlação não parece ser linear. 
6.1.9 - Interação com fibroblastos cancerosos $\mathrm{He}-\mathrm{La}$
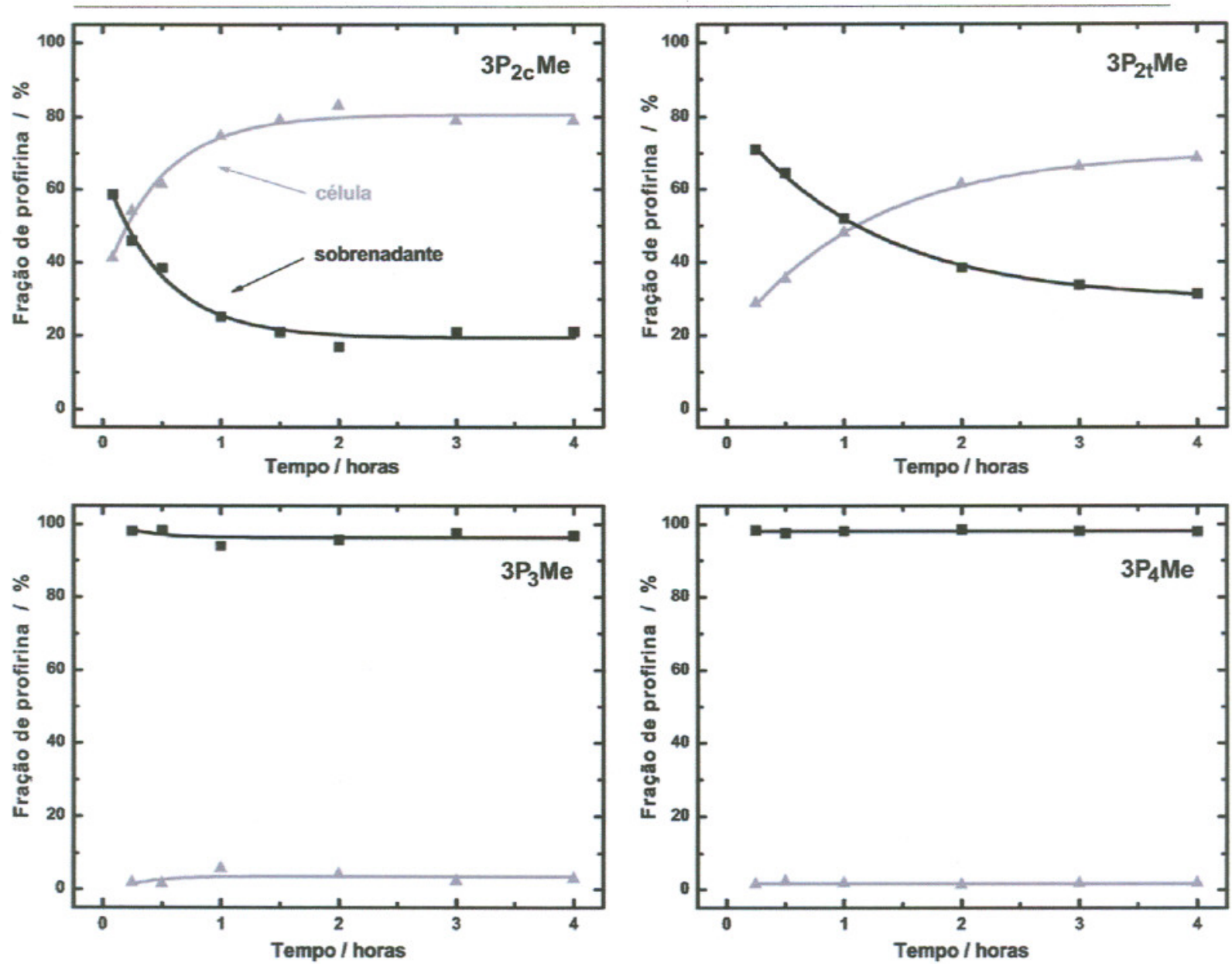

Figura 43: Fração da concentração da 3SMe (inicialmente $\sim 60 \mu \mathrm{M}$ ), ligadas às células He-La ( ${ }^{\star}$ - cinza; $10^{6}$ células $/ \mathrm{mL}$ ) e livre na solução ( $\mathbf{~ - ~ p r e t o ) , ~ e m ~}$ função do tempo de incubação em solução de PBS à $37^{\circ} \mathrm{C}$. 


\subsection{CONCLUSÃO}

O foco principal do projeto consistiu em relacionar a estrutura química de 20 porfirinas catiônicas com sua atividade fotodinâmica. Estes fotossensibilizadores, contendo número e disposição de cargas positivas diferentes ao redor do anel porfirínico, permitem variar gradativamente a relação entre hidrofobicidade/lipofilicidade. De modo que, constituem estruturas interessantes para estudar 0 efeito daquele fator sobre a ligação com membranas biológicas, em específico a mitocôndrial, devido a possibilidade da interação com esta organela ser favorecida pelo potencial negativo de membrana.

Assim, foram preparadas, purificadas e caracterizadas quatro séries de fotossensibilizadores porfirinicos contendo 1, 2, 2, 3 e 4 grupos $N$-3-piridil ou $N$ 4-piridil, coordenados a grupos metila ou $\left[\mathrm{Ru}(\mathrm{bipy})_{2} \mathrm{Cl}\right]^{+}$. De um modo geral, as espécies metiladas são mais solúveis em água quando comparadas com as respectivas espécies rutenadas, exceto pelas espécies monocatiônicas. Verificou-se que as porfirinas com grupos 4-metilpiridinio apresentam uma tendência maior à agregação que aqueles com 3-metilpiridínio, mesmo em solução aquosa. Este processo se intensifica com o aumento da força iônica do meio e a diminuição do número de grupos eletricamente carregados periféricos.

A agregação afeta significativamente o processo de transferência de energia para $\circ \mathrm{O}_{2}$ em $\mathrm{D}_{2} \mathrm{O}$, devido à diminuição dos fotosensibilizadores no estado excitado. Quando aquele processo está ausente como na série de porfirinas $3 S \mathrm{Me}$, verificou-se que os valores de $\phi_{\Delta}$ são praticamente independentes do número de grupos 3-metilpiridinio, enquanto que no caso dos derivados 4-metilpiridínio que apresentam maior tendência de associação observou-se uma dependência inversa em função do número daqueles grupos

Os coeficientes de partição em n-octanol/água apresentaram uma dependência linear em função do número de residuos fenila. Ou seja, o log POA diminui com o aumento do número de cargas positivas nas moléculas de 
porfirina. Como esperado, os isômeros meta demonstraram ser mais hidrofilicos que os para. Contudo, a coordenação dos complexos de rutênio, contendo duas moléculas de bipiridina para cada átomo de rutênio, promoveu um aumento da hidrofobicidade das porfirinas, em relação à metilação.

A velocidade de hemólise de eritrócitos mostrou ser bastante sensivel aos coeficientes de partição dos sensibilizadores porfirínicos na membrana celular. Em especial as espécies metiladas contendo uma carga e as rutenadas contendo uma e duas cargas positivas demonstraram causar hemólise instantânea, mesmo no escuro. Neste caso, a elevada hidrofobicidade destas amostras devem levar à agregação dos mesmos na membrana celular, provocando danos à mesma. Além disso, as porfirinas rutenadas contendo 3 e 4 grupos $\left[\mathrm{Ru}(\text { bipy })_{2} \mathrm{Cl}^{+}\right.$apresentaram um comportamento que parece consistente com a descoordenação dos complexos periféricos ou precipitação em meio com força iônica elevada (PBS).

Para as demais espécies a eficiência do processo de hemólise fotoinduzida pelas porfirinas foi proporcional ao log $\mathrm{POA}_{\mathrm{OA}}$, exceto no caso das $P_{2 c} M e$, seguindo a seqüência $P_{2 c} M e>>P_{2 t} M e>P_{3} M e>P_{4} M e$. Em geral os isômeros dicatiônicos metilados cis apresentaram uma eficiência 7 vezes superior aos trans, indicando que essas espécies apresentam o melhor compromisso entre hidrofobicidade e hidrofilicidade e uma estrutura adequada para penetrar na membrana celular, devido ao seu caráter anfipático. Logo, a escolha adequada da estrutura do fotossensibilizador é crítica em aplicações fotodinâmicas.

A determinação das constantes de ligação e eficiência de lesão fotooxidativa às mitocôndrias isoladas apresentou a mesma dependência dos coeficientes de partição em relação à estrutura. E o potencial de membrana mitocondrial influencia a constante de ligação, levando a um acréscimo de cerca de $15 \%$ na concentração de $\mathrm{P}_{2 c} \mathrm{Me}$ e $\mathrm{P}_{2 \downarrow} \mathrm{Me}$ incorporada e de $~ 8 \%$ no caso das $\mathrm{P}_{3} \mathrm{Me}$ e $\mathrm{P}_{4} \mathrm{Me}$, em comparação com a mitocôndria desacoplada. $\mathrm{O}$ estudo comparativo, utilizando lipossomos como sistemas modelos, corroborou aqueles resultados de constante de ligação, sugerindo que ligação destes corantes à mitocôndria e eritrócitos não ocorre por interação com sítios 
específicos, mas são decorrentes de interações não específicas. Logo, a eficiência do processo de peroxidação lipídica fotoinduzido da membrana mitocondrial e celular de eritrócito deve-se exclusivamente à partição do fotossensibilizador no interior destas estruturas. Ou seja, os danos oxidativos ocorrerão tão mais rapidamente quanto maior for à penetração do corante na bicamada lipidica.

Assim, a baixa atividade das $\mathrm{P}_{4} \mathrm{Me}$ pode ser atribuida a sua fraca interação com membrana, devido à ausência de grupos hidrofóbicos (fenilas) que atuam como pontos de ancoragem. Neste caso, é provável que a porfirina esteja localizada no seio da solução ou ainda próxima da superficie da membrana devido à atração eletrostática que possa existir com os fosfolipídios de membrana (figura 44). No caso das $P_{3} M e$, a presença de um grupo um fenila em suas estruturas propicia uma maior afinidade, mas a presença de três cargas positivas torna a molécula muito hidrofilica, diminuindo 0 coeficiente de partição. As $\mathrm{P}_{2 t} \mathrm{Me}$ apresentam o dobro de sítios de ligação em relação as $\mathrm{P}_{3} \mathrm{Me}$, mas devido à sua estrutura apenas um dos grupos pode ser utilizado para ancoragem na membrana. Contudo, a hidrofobicidade aumenta e a probabilidade de interação aumentam. Em contraste, a estrutura cis das $\mathrm{P}_{2 \mathrm{c}} \mathrm{Me}$ permite a eficiente penetração da porfirina na membrana. Assim, 0 caráter anfipático confere a estas espécies uma maior solubilidade em água e uma maior capacidade de penetração à bicamada lipídica, em relação às demais estruturas. 


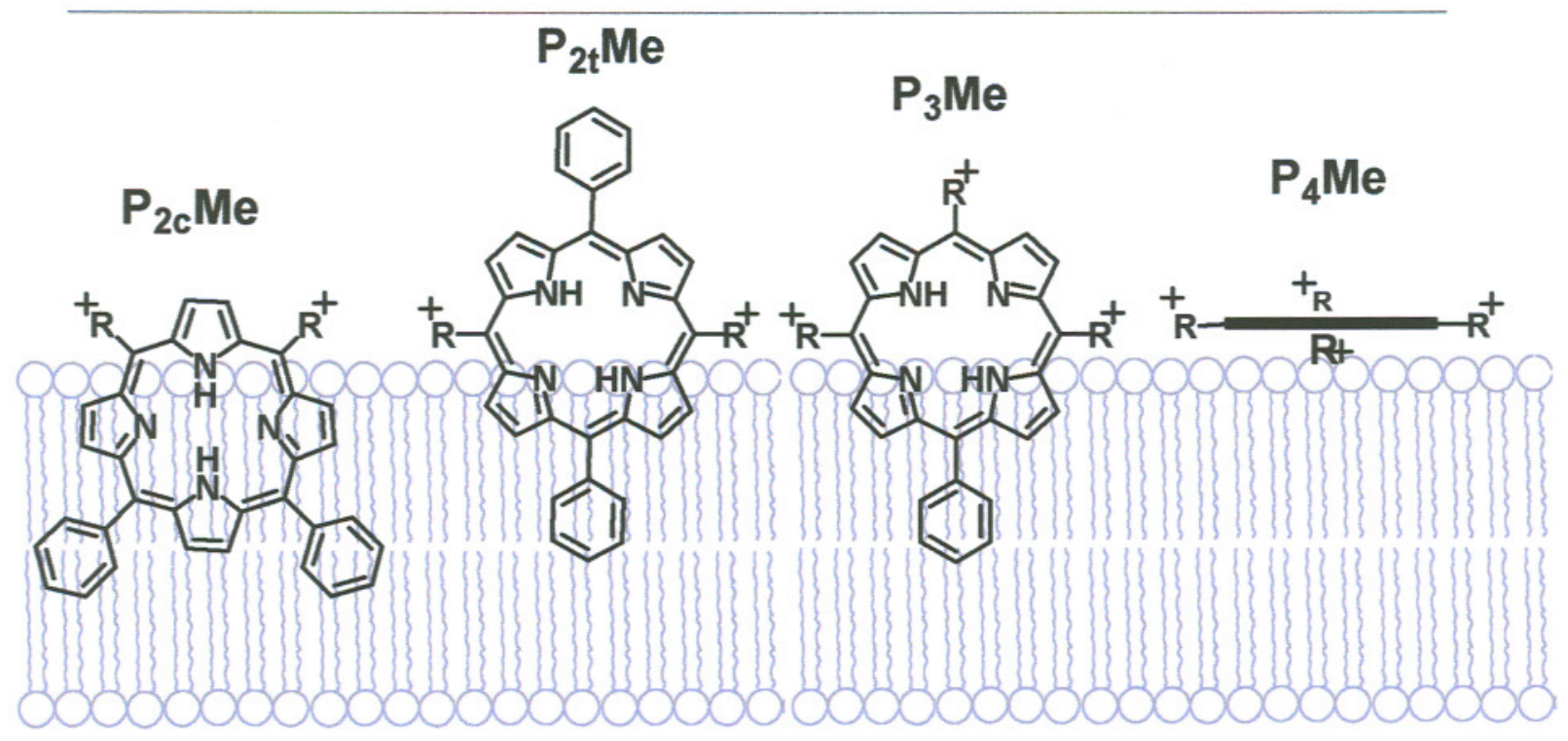

Figura 44: Esquema ilustrativo mostrando a possivel disposição das porfirinas metiladas numa membrana. Note que os grupos hidrofilicos sempre estão voltados para fora, enquanto as regiões lipofilicas penetram na mesma.

Os resultados experimentais dos efeitos fotodinâmicos das porfirinas catiônicas na presença de eritrócitos, mitocôndrias e células HeLa são consistentes com as asserções acima. Porém, no caso da taxa de ligação com células cancerosas HeLa não foi observado uma correlação linear entre os coeficientes de partição e a capacidade de ligação como nos outros casos estudados. A ligação demonstrou ser extremamente elevada para as $\mathrm{P}_{2 c} \mathrm{Me} e$ $\mathrm{P}_{2 \mathrm{t}} \mathrm{Me}$, sendo necessário somente 12 e 67 minutos para reduzir a concentração da solução para a metade, enquanto as $\mathrm{P}_{3} \mathrm{Me}$ e $\mathrm{P}_{4} \mathrm{Me}$ apresentaram afinidade muito baixa pela membrana. Estes resultados sugerem que a HeLa pode possuir sitios de reconhecimento adequados para aquelas espécies dicatiônicas.

Os resultados apresentados neste estudo mostraram a necessidade de um balanço adequado entre hidrofilicidade e lipofilicidade, além de uma estrutura adequada, nos fotossensibilizadores para terapia fotodinâmica. A 
adequada disposição espacial dos sítios hidrofilicos e lipofilicos na molécula é fundamental para a interação/penetração na membrana celular ou mitocondrial, aumentando a eficiências dos processos foto-oxidativos. As porfirinas contendo grupos 3-metilpiridínio apresentam uma vantagem sobre as 4-metilpiridinio, normalmente estudadas, por serem mais hidrofilicas e possuírem atividade fotodinâmica similar. Em especial a estrutura anfipática da $3 \mathrm{P}_{2 \mathrm{c}} \mathrm{Me}$ associada ao elevado rendimento quântico de formação de ${ }^{1} \mathrm{O}_{2} \mathrm{e}$ estabilidade, the confere uma grande potencialidade como agente fototerapêutico. 


\section{BIBLIOGRAFIA}

[1] Stewart, F., Baas, P. and Star, W. (1998) Radiotherapy and Oncology 48, 233-248.

[2] Elsaleh, H., Robbins, P., Joseph, D., Powell, B., Grieu, F., Menso, L. and lacopetta, B. (2000) Radiotherapy and Oncology 56, 239-244.

[3] Allen, C.M., Sharman, W.M., La Madeleine, C., Weber, J.M., Langlois, R., Ouellet, R. and van Lier, J.E. (1999) Photochemistry and Photobiology 70, 512-523.

[4] Angelopoulou, K., Yu, H., Bharaj, B., Giai, M. and Diamandis, E.P. (2000) Clinical Biochemistry 33, 53-62.

[5] Banfi, S., Caruso, E., Caprioli, S., Mazzagatti, L., Canti, G., Ravizza, R., Gariboldi, M. and Monti, E. (2004) Bioorganic \& Medicinal Chemistry 12, 4853-4860.

[6] Simplicio, F.I., Maionchi, F. and Hioka, N. (2002) Quimica Nova 25, 801807.

[7] Kessel, D., Woodburn, K., Henderson, B.W. and Chang, C.K. (1995) Photochemistry and Photobiology 62, 875-881.

[8] Madsen, S.J., Sun, C.H., Tromberg, B.J., Wallace, V.P. and Hirschberg, H. (2000) Photochemistry and Photobiology 72, 128-134.

[9] Mori, H., Sakata, I., Hirano, T., Obana, A., Nakajima, S., Hikida, M. and Kumagai, T. (2000) Japanese Journal of Cancer Research 91, 753-759.

[10] Nakamura, T., Fukui, H., Fujita, M., Fujimori, T., Ishii, Y., Ejiri, M. and Maeda, S. (2000) Gastrointestinal Endoscopy 51, 7064.

[11] Ruck, A., Kollner, T., Dietrich, A., Strauss, W. and Schneckenburger, H. (1992) Journal of Photochemistry and Photobiology B-Biology 12, 403412.

[12] Bonnett, R., Charlesworth, P., Djelal, B.D., Foley, S., McGarvey, D.J. and Truscott, T.G. (1999) Journal of the Chemical Society-Perkin Transactions 2, 325-328.

[13] Alvarez, M.G., Yslas, E.I., Rivarola, V., Mori, G., La Penna, M., Silber, J.J. and Durantini, E.N. (2000) Molecules 5, 379-380. 
[14] Lang, K., Mosinger, J. and Wagnerova, D.M. (2004) Coordination Chemistry Reviews 248, 321-350.

[15] Dimascio, P., Bechara, E.J.H., Medeiros, M.H.G., Briviba, K. and Sies, H. (1994) Febs Letters 355, 287-289.

[16] Girotti, A.W. (2001) Journal of Photochemistry and Photobiology BBiology 63, 103-113.

[17] DeRosa, M.C. and Crutchley, R.J. (2002) Coordination Chemistry Reviews 233, 351-371.

[18] Bando, N., Hayashi, H., Wakamatsu, S., Inakuma, T., Miyoshi, M., Nagao, A., Yamauchi, R. and Terao, J. (2004) Free Radical Biology and Medicine 37, 1854-1863.

[19] Halliwell, B. and Gutteridge, J.M.C. Oxford.

[20] Kessel, D. (2004) Photodiagnosis and Photodynamic Therapy 1, 3-7.

[21] Webber, J., Herman, M., Kessel, D. and Fromm, D. (2000) Langenbecks Archives of Surgery 385, 299-304.

[22] Sibata, M.N., Tedesco, A.C. and Marchetti, J.M. (2004) European Journal of Pharmaceutical Sciences 23, 131-138.

[23] Cernay, T. and Zimmermann, H.W. (1996) Journal of Photochemistry and Photobiology B-Biology 34, 191-196.

[24] Zimmermann, A., Ritsch-Marte, M. and Kostron, H. (2001) Photochemistry and Photobiology 74, 611-616.

[25] Lemasters, J.J. (1999) American Journal of Physiology-Gastrointestinal and Liver Physiology 276, G1-G6.

[26] Morgan, J. and Oseroff, A.R. (2001) Advanced Drug Delivery Reviews 49, 71-86.

[27] Jaeschke, H. and Lemasters, J.J. (2003) Gastroenterology 125, 12461257.

[28] Ball, D.J., Luo, Y., Kessel, D., Griffiths, J., Brown, S.B. and Vernon, D.I. (1998) Journal of Photochemistry and Photobiology B-Biology 42, 159163.

[29] Chen, L.B. (1998) Annual Review of Cell Biology 4.

[30] Gabrielli, D., Belisle, E., Severino, D., Kowaltowski, A.J. and Baptista, M.S. (2004) Photochemistry and Photobiology 79, 227-232. 
[31] Ricchelli, F., Franchi, L., Miotto, G., Borsetto, L., Gobbo, S., Nikolov, P., Bommer, J.C. and Reddi, E. (2005) International Journal of Biochemistry \& Cell Biology 37, 306-319.

[32] Merchat, M., Spikes, J.D., Bertoloni, G. and Jori, G. (1996) Journal of Photochemistry and Photobiology B-Biology 35, 149-157.

[33] Ferreira, S., Tedesco, A.C., Sousa, G., Zangaro, R.A., Silva, N.S., Pacheco, M.T.T. and Pacheco-Soares, C. (2004) Lasers in Medical Science 18, 207-212.

[34] Pandey, R.K. (2000) Journal of Porphyrins and Phthalocyanines 4, 368373.

[35] Mody, T.D. (2000) Journal of Porphyrins and Phthalocyanines 4, 362367.

[36] Chowdhary, R.K.R.L.G.C.A.J.W.J.D.R.A.M.L.J.G. (1998)

Biopharmaceutics \& Drug Disposition 19, 395.

[37] Miller, J.W. et al. (1999) Archives of Ophthalmology 117, 1161-1173.

[38] Mones, J. (1999) Investigative Ophthalmology \& Visual Science 40, 1703 B611.

[39] Borissevitch, I.E., Tominaga, T.T., Imasato, H. and Tabak, M. (1997) Analytica Chimica Acta 343, 281-286.

[40] Csik, G., Balog, E., Voszka, I., Tolgyesi, F., Oulmi, D., Maillard, P. and Momenteau, M. (1998) Journal of Photochemistry and Photobiology BBiology 44, 216-224.

[41] Kuzelova, K. and Brault, D. (1994) Biochemistry, 9447-9459.

[42] Ruck, A., Beck, G., Bachor, R., Akgun, N., Gschwend, M.H. and Steiner, R.J. (1996) Photochem. Photobiol. B-Biology, 127-133.

[43] Berg, K., Madslien, K., Bommer, J.C., Oftebro, R., Winkelman, J.W. and Moan, J. (1991) Photochemistry and Photobiology 53, 203-210.

[44] Furuta, H., Asano, T. and Ogawa, T. (1994) Journal of the American Chemical Society 116, 767-768.

[45] Maeda, H., Osuka, A. and Furuta, H. (2003) Supramol. Chem. 15, in press.

[46] Furuta, H., Maeda, H., Osuka, A., Yasutake, M., Shinmyozu, T. and Ishikawa, Y. (2000) Chemical Communications, 1143-1144. 
[47] Furuta, H., Maeda, H. and Osuka, A. (2000) Journal of the American Chemical Society $122,803-807$.

[48] Furuta, H., Ogawa, T., Uwatoko, Y. and Araki, K. (1999) Inorganic Chemistry 38, 2676-2682.

[49] Araki, K., Winnischofer, H., Toma, H.E., Maeda, H., Osuka, A. and Furuta, H. (2001) Inorganic Chemistry 40, 2020-2025.

[50] Furuta, H., Maeda, H. and Osuka, A. (2002) Organic Letters 4, 181-184.

[51] Engelmann, F.M., Mayer, I., Araki, K., Toma, H.E., Baptista, M.S., Maeda, H., Osuka, A. and Furuta, H. (2004) Journal of Photochemistry and Photobiology a-Chemistry 163, 403-411.

[52] Araki, K., Engelmann, F.M., Mayer, I., Toma, H.E., Baptista, M.S., Maeda, H., Osuka, A. and Furuta, H. (2003) Chemistry Letters 32, 244245.

[53] Srinivasan, A., Ishizuka, T., Osuka, A. and Furuta, H. (2003) J. AM. CHEM. SOC COM 125, 878-879.

[54] Li, H.D., Fedorova, O.S., Grachev, A.N., Trumble, W.R., Bohach, G.A. and Czuchajowski, L. (1997) Biochimica Et Biophysica Acta-Gene Structure and Expression 1354, 252-260.

[55] Sehlstedt, U., Kim, S.K., Carter, P., Goodisman, J., Vollano, J.F., Norden, B. and Dabrowiak, J.C. (1994) Biochemistry 33, 417-426.

[56] Pastemack, R.F., Giannetto, A., Pagano, P. and Gibbs, E.J. (1991) Journal of the American Chemical Society 113, 7799-7800.

[57] Kruk, N.N., Shishporenok, S.I., Korotky, A.A., Galievsky, V.A., Chirvony, V.S. and Turpin, P.Y. (1998) Journal of Photochemistry and Photobiology B-Biology 45, 67-74.

[58] Sari, M.A., Battioni, J.P., Dupre, D., Mansuy, D. and Lepecq, J.B. (1988) Biochemical Pharmacology 37, 1861-1862.

[59] Pasternack, R.F. and Gibbs, E.J. (1983) Inorganica Chimica ActaBioinorganic Chemistry 79, 7-7.

[60] Mukundan, N.E., Petho, G., Dixon, D.W., Kim, M.S. and Marzilli, L.G. (1994) Inorganic Chemistry 33, 4676-4687.

[61] Tjahjono, D.H., Akutsu, T., Yoshioka, N. and Inoue, H. (1999) Biochim. Biophys. Acta 1472, 333-343. 
[62] Schneider, H.J. and Wang, M. (1994) Journal of Organic Chemistry 59, 7464-7472.

[63] Ambroise, A. and Maiya, B.G. (2000) Inorganic Chemistry 39, 42564263.

[64] Lincoln, P. and Norden, B. (1998) Journal of Physical Chemistry B 102, 9583-9594.

[65] Eriksson, M., Leijon, M., Hiort, C., Norden, B. and Graslund, A. (1994) Biochemistry 33, 5031-5040.

[66] Ravanat, J.L., Cadet, J., Araki, K., Toma, H.E., Medeiros, M.H.G. and Di Mascio, P. (1998) Photochemistry and Photobiology 68, 698-702.

[67] Toma, H.E., Serrasqueiro, R.M., Rocha, R.C., Demets, G.J.F., Winnischofer, H., Araki, K., Ribeiro, P.E.A. and Donnici, C.L. (2000) Journal of Photochemistry and Photobiology a-Chemistry 135, 185-191.

[68] Toma, H.E. and Araki, K. (2000) Coordination Chemistry Reviews 196, 307-329.

[69] Petho, G., Elliott, N.B., Lin, M., Marzilli, L.G., Kim, M.S. and Dixon, D.W. (1993) Magyar Kemiai Folyoirat 99, 417-419.

[70] Fleischer, E.B. and Shachter, A.M. (1991) Inorganic Chemistry 30, 37633769.

[71] Meng, G.G., James, B.R., Skov, K.A. and Korbelik, M. (1994) Canadian Journal of Chemistry-Revue Canadienne De Chimie 72, 2447-2457.

[72] Araki, K., Losco, P., Engelmann, F.M., Winnischofer, H. and Toma, H.E. (2001) Journal of Photochemistry and Photobiology a-Chemistry 142, 25-30.

[73] Engelmann, F.M., Losco, P., Winnischofer, H., Araki, K. and Toma, H.E. (2002) Journal of Porphyrins and Phthalocyanines 6, 33-42.

[74] Spiller, W., Kliesch, H., Wohrle, D., Hackbarth, S., Roder, B. and Schnurpfeil, G. (1998) Journal of Porphyrins and Phthalocyanines 2, 145-158.

[75] Khalili, M. and Grossweiner, L.I. (1997) Journal of Photochemistry and Photobiology B-Biology 37, 236-244.

[76] Bilgin, M.D., Al-Akhras, M.A., Khalili, M., Hemmati, H. and Grossweiner, L.I. (2000) Photochemistry and Photobiology 72, 121-127. 
[77] Netto, L.E., Kowaltowski, A.J., Castilho, R.F. and Vercesi, A.E. (2002) Methods Enzymol., 260-270.

[78] Rouser, G., Fleische.S and Yamamoto, A. (1970) Lipids 5, 494-\&.

[79] Flamigni, L., Barigelletti, F., Armaroli, N., Collin, J.P., Sauvage, J.P. and Williams, J.A.G. (1998) Chemistry-a European Journal 4, 1744-1754.

[80] Schmidt-Erfurth, U., Flotte, T.J., Gragoudas, E.S., Schomaker, K., Birngruber, R. and Hasan, T. (1996) Experimental Eye Reserach 62, 110.

[81] Schmidt-Erfurth, U. et al. (1998) Graefes Archive for Clinical and Experimental Ophthalmology 236, 365-374.

[82] Schmidt-Erfurth, U. et al. (1999) Archives Of Ophthalmology 117, 1177.

[83] Meng, G.Z.G., James, B.R. and Skov, K.A. (1994) Canadian Journal of Chemistry-Revue Canadienne De Chimie 72, 1894-1909.

[84] Mayer, I., Araki, K., Formiga, A.L.B., Engelmann, F.M., Winnischofer, H. and Toma, H.E. (2005) Inorganic Chimica Acta no prelo.

[85] Kepczynski, M., Pandian, R.P., Smith, K.M. and Ehrenberg, B. (2002) Photochemistry and Photobiology 76, 127-134.

[86] Seiler, P. (1974) European Journal of Medicinal Chemistry 9, 473-479.

[87] Eltayar, N., Tsai, R.S., Testa, B., Carrupt, P.A. and Leo, A. (1991) Journal of Pharmaceutical Sciences 80, 590-598.

[88] Ran, Y.Q., He, Y., Yang, G., Johnson, J.L.H. and Yalkowsky, S.H. (2002) Chemosphere 48, 487-509. 


\section{CURRICULUM VITAE}

\section{FÁBIO MONARO ENGELMANN}

Nascido em São Paulo, São Caetano do Sul, em 12 de fevereiro de 1976, casado.

\section{FORMAÇÃO ACADEMICA}

Doutorado em Química

2001-2005

Laboratório de Química Supramolecular e Nanotecnologia (LQSN) - Instituto de Química - Universidade de São Paulo/SP

Tema: Derivados Porfirínicos como Fotossensibilizadores para Terapia Fotodinâmica.

- Projeto premiado com financiamento por 4 anos pela FAPESP.

Mestrado em Química

1999-2001

Laboratório de Química Supramolecular e Nanotecnologia (LQSN) - Instituto de Química - Universidade de São Paulo/SP

Tema: Fotoquímica e fotofísica de complexos supramoleculares e suas potencialidades em terapia fotodinâmica.

- Projeto premiado com financiamento de 2 anos pela FAPESP.

\section{Graduação em Ciências Moleculares}

1995-1999

Curso de Ciências Moleculares - Universidade de São Paulo/SP

Laboratório de Química Supramolecular e Nanotecnologia (LQSN) - Instituto de Química - Universidade de São Paulo/SP

Tema: Química supramolecular de derivados porfirínicos.

- Projeto premiado com financiamento de 3,5 anos pelo CNPq e FAPESP.

\section{Colegial Técnico em Química Industrial}

1991-1994

Senai Mário Amato

Tema: Desenvolvimento de método para reciclagem de óleo solúvel industrial. 
Graduação em Ciências Farmacêuticas (em andamento) 2004-

Faculdade de Ciências Farmacêuticas - Universidade de São Paulo/SP

\section{EXPERIÊNCIA PROFISSIONAL}

\section{Syntechrom-Heubach do Brasil Indústria de Pigmentos e Derivados Ltda}

Setor: Laboratório de pesquisa e desenvolvimento.

Cargo: Químico - nível técnico.

Função: Pesquisa e desenvolvimento de pigmentos orgânicos.

Período: 04/1994 - 07/1995.

\section{RESUMOS EM CONGRESSOS}

36 trabalhos publicados em livros de resumos ou anais de eventos

\section{PUBLICAÇÕES EM REVISTAS INTERNACIONAIS}

1) Mayer I, Formiga ALB, Engelmann FM, Winnischofer H, Oliveira PV, Tomazela DM, Eberlin MN, Toma ET, Araki K, Study of the Spectroscopic and Electrochemical Properties of Tetraruthenated Porphyrins by Theoretical-Experimental Approach, Inorganica Chimica Acta, Aceito em 10/02/2005.

2) Engelmann FM, Mayer I, Araki K, Toma HE, Baptista MS, Maeda H, Osuka $A$, Furuta $\mathrm{H}$, Photochemistry of doubly $\mathrm{N}$-confused porphyrin bonded to non-conventional high oxidation state $\mathrm{Ag}(\mathrm{III})$ and $\mathrm{Cu}(\mathrm{III})$ ions, Journal of Photochemistry and Photobiology A-Chemistry 163 (3): 403-411 May 212004.

3) Araki K, Winnischofer H, Viana HEB, Toyama MM, Engelmann FM, Mayer I, Formiga ALB, Toma HE, Enhanced electrochemical and electrocatalytic activity of a new supramolecular manganese-porphyrin species containing four bis(bipyridine)(aqua)ruthenium(II) complexes, Journal of Electroanalytical Chemistry 562 (2): 145-152 Feb 12004.

4) Nogueira AF, Formiga ALB, Winnischofer $H$, Nakamura M, Engelmann FM, Araki $\mathrm{K}$, Toma HE, Photoelectrochemical properties of supramolecular species containing 
porphyrin and ruthenium complexes on $\mathrm{TiO}_{2}$ films, Photochemical \& Phorobiological Sciences 3 (1): 56-62 2004.

5) Tomazela DM, Gozzo FC, Mayer I, Engelmann FM, Araki K, Toma HE, Eberlin $\mathrm{MN}$, Electrospray mass and tandem mass spectrometry of homologous and isomeric singly, doubly, triply and quadruply charged cationic ruthenated meso-(phenyl)n-(metaand para-pyridyl)m $(n+m=4)$ macrocyclic porphyrin complexes. Journal of Mass Spectrometry 39: 1161-1167, 2004.

6) Anaissi FJ, Engelmann FM, Araki K, Toma HE, Porphyrin doped vanadium pentoxide xerogel as electrode material, Solid State Sciences 5 (4): 621-628 Apr 2003.

7) Araki K, Engelmann FM, Mayer I, Toma HE, Baptista MS, Maeda H, Osuka A, Furuta $\mathrm{H}$, Doubly $\mathrm{N}$-confused porphyrins as efficient sensitizers for singlet oxygen generation, Chemistry Letters 32 (3): 244-245 Mar 52003.

8) Winnischofer H, Engelmann FM, Toma HE, Araki K, Rechenberg HR, Acid-base and spectroscopic properties of a novel supramolecular porphyrin bonded to four pentacyanoferrate(II) groups, Inorganica Chimica Acta 338: 27-35 oct 142002.

9) Engelmann FM, Losco P, Winnischofer H, Araki K, Toma HE, Synthesis, electrochemistry, spectroscopy and photophysical properties of a series of mesophenylpyridylporphyrins with one to four pyridyl rings coordinated to $\left[R u(b i p y)_{2} \mathrm{Cl}\right]^{+}$ groups, Journal of Porphyrins and Phthalocyaninces 6 (1): 33-42 2002.

10) Araki K, Losco P, Engelmann FM, Winnischofer H, Toma HE, Modulation of vectorial energy transfer in the tetrakis[tris(bipyridine)ruthenium(II)] porphyrinate zinc complex, Journal of Photochemistry and Photobiology A-Chemistry 142 (1): 25-30 Aug 202001. 